\title{
Factors Controlling Reservoir Quality in Tertiary Sandstones and Their Significance to Geopressured Geothermal Production
}

\author{
R. G. Loucks, D. L. Richmann, and K. L. Milliken \\ Assisted by M. M. Elliot, J. L. Forman, L. A. Jirik, C. L. McCall, \\ J. R. Suter, and L. S. Underwood
}

\section{DISCLAIMER}

\begin{abstract}
This report was prepared as an account of work sponsored by an agency of the United States Government. Neither the United States Government nor any agency thereof, nor any of their employees, makes any warranty, express or implied, or assumes any legal liability or responsibility for the accuracy, completeness, or usefulness of any information, apparatus, product, or process disclosed, or represents that its use would not infringe privately owned rights. Reference herein to any specific commercial product, process, or service by trade name, trademark, manufacturer, or otherwise does not necessarily constitute or imply its endorsement, recommendation, or favoring by the United States Government or any agency thereof. The views and opinions of authors expressed herein do not necessarily state or reflect those of the United States Government or any agency thereof.
\end{abstract}

1981
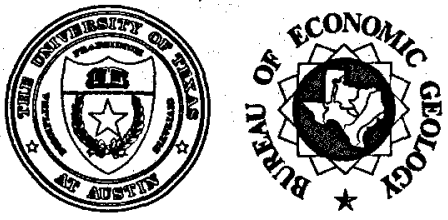

\section{Bureau of Economic Geology • W. L. Fisher, Director The University of Texas at Austin • Austin, Texas 78712}

Prepared for the U.S. Department of Energy under Contract Number DE-AC08-79ET27111

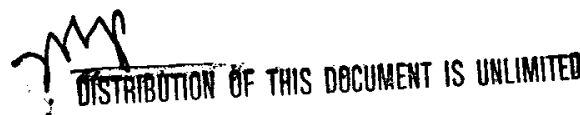




\section{DISCLAIMER}

This report was prepared as an account of work sponsored by an agency of the United States Government. Neither the United States Government nor any agency Thereof, nor any of their employees, makes any warranty, express or implied, or assumes any legal liability or responsibility for the accuracy, completeness, or usefulness of any information, apparatus, product, or process disclosed, or represents that its use would not infringe privately owned rights. Reference herein to any specific commercial product, process, or service by trade name, trademark, manufacturer, or otherwise does not necessarily constitute or imply its endorsement, recommendation, or favoring by the United States Government or any agency thereof. The views and opinions of authors expressed herein do not necessarily state or reflect those of the United States Government or any agency thereof. 


\section{DISCLAIMER}

Portions of this document may be illegible in electronic image products. Images are produced from the best available original document. 


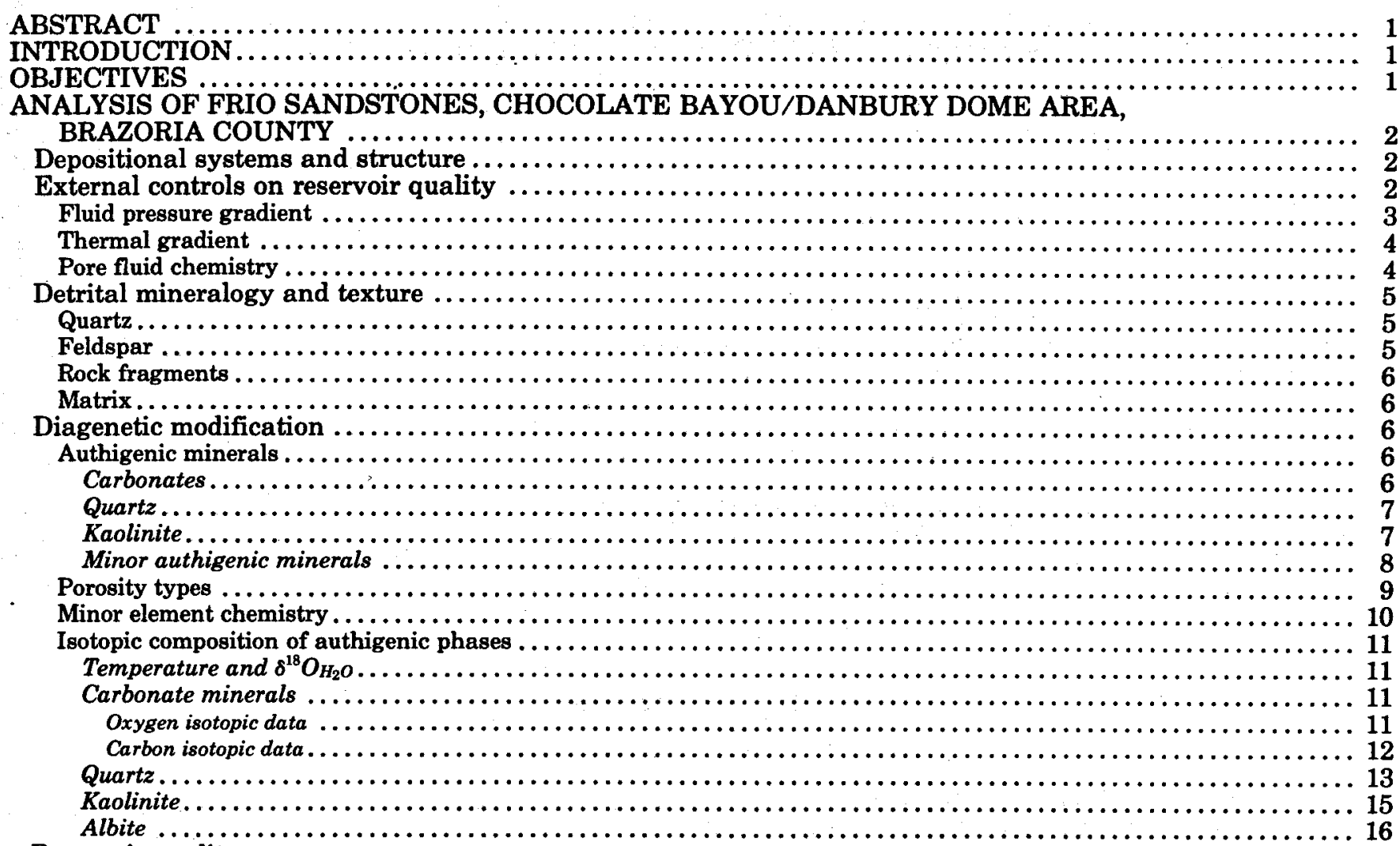

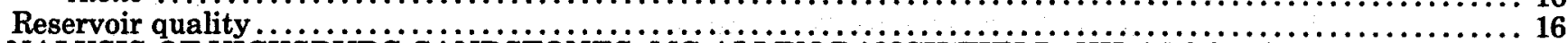

ANALYSIS OF VICKSBURG SANDSTONES, MC ÄLEN RÄC̈H FIELD, HiDÄL

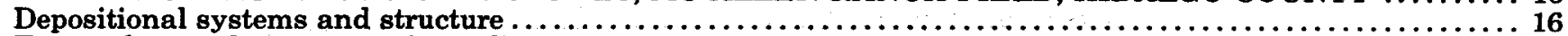

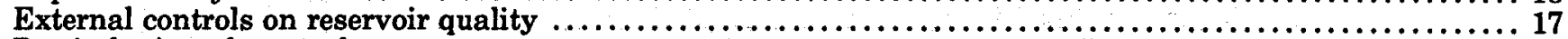

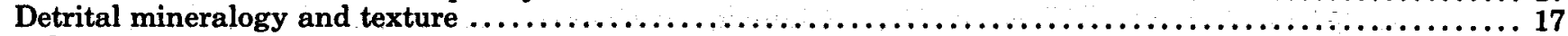

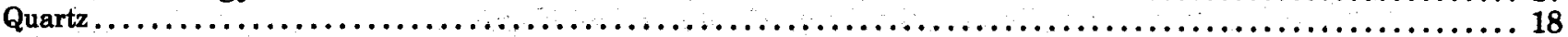

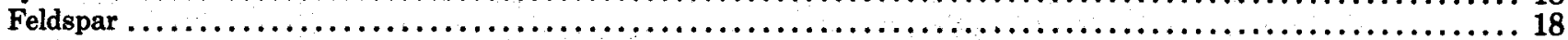

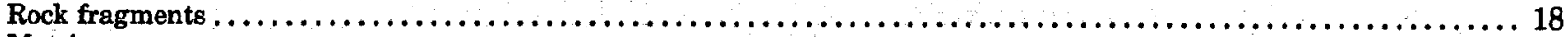

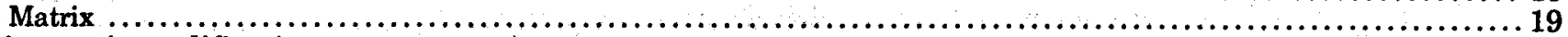

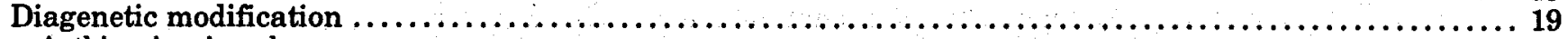

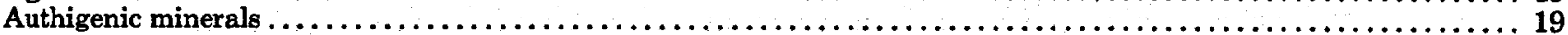

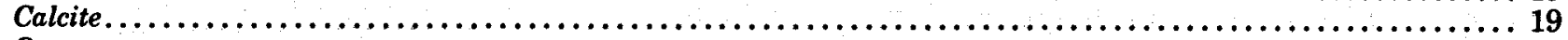

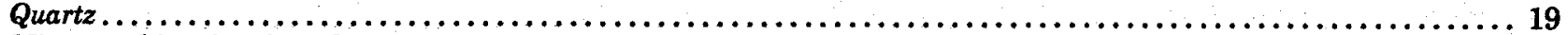

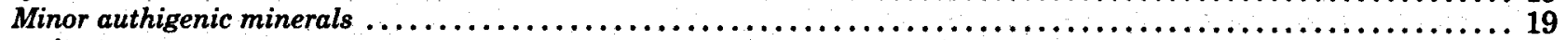

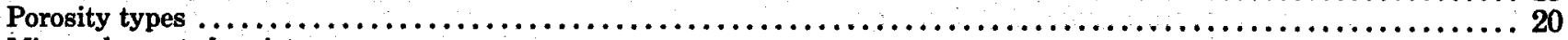

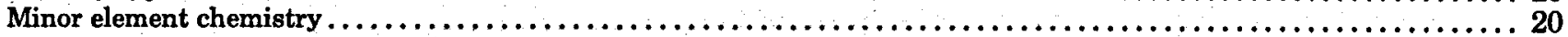




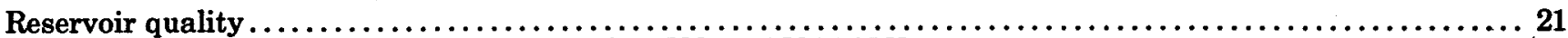
PHYSICAL FACTORS CONTROLLING RESERVOIR QUALITY $\ldots \ldots \ldots \ldots \ldots \ldots \ldots \ldots \ldots \ldots \ldots \ldots \ldots, 21$

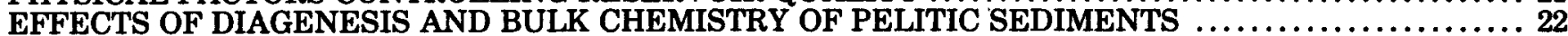

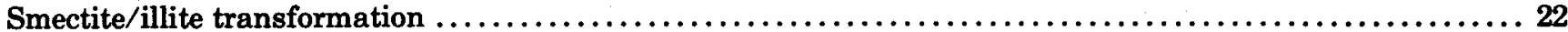

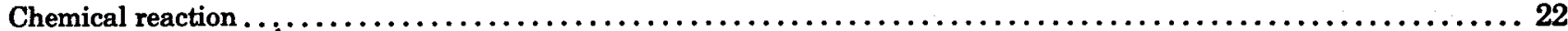

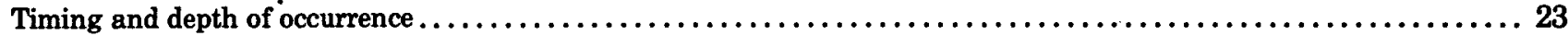

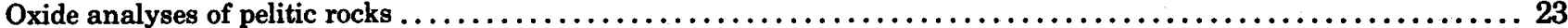

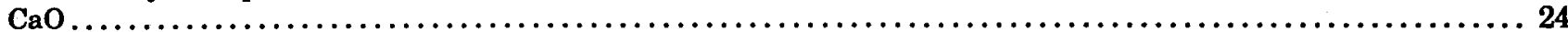

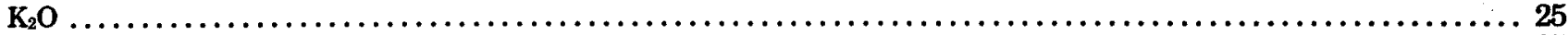

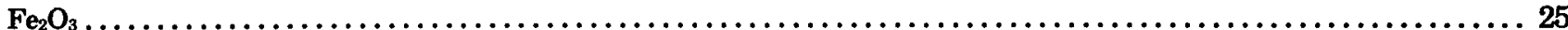

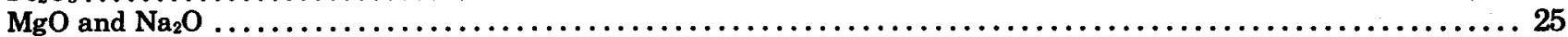

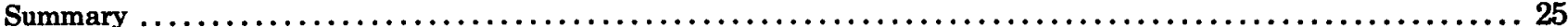

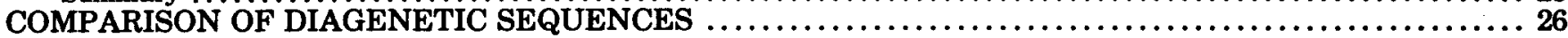

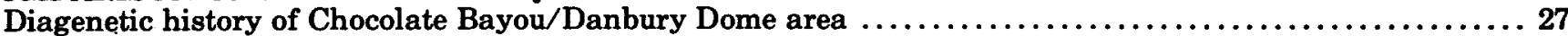

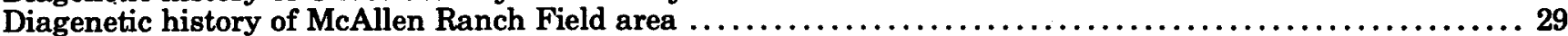

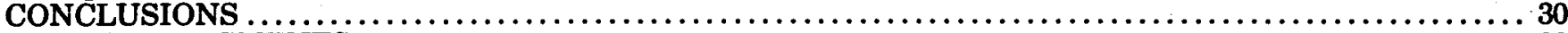

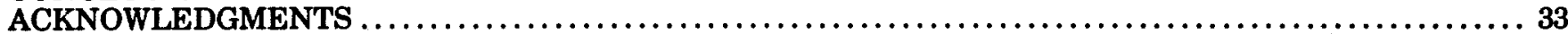

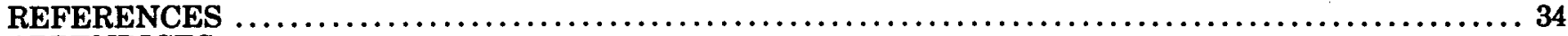

APPENDICES

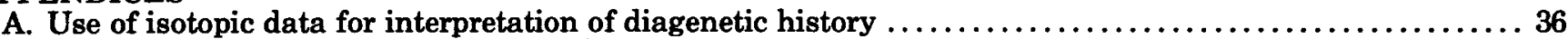

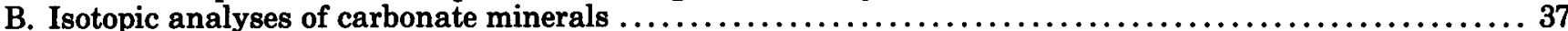

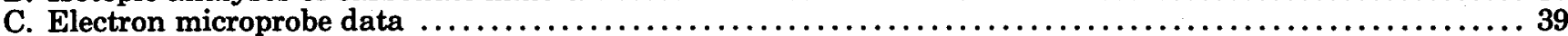

\section{Text Illustrations}

Text Figures

1. Location of samples used in this study

2. Sample distribution with depth

3. Depositional style of Tertiary strata along the Texas coast

4. Temperature versus depth, Brazoria County, Texas...

5. Generalized salinity trends, Brazoria County, Texas.

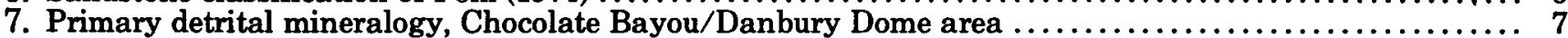

8. Chessboard twinning resulting from albitization of potassium feldspar $\ldots \ldots \ldots \ldots \ldots \ldots \ldots \ldots \ldots \ldots \ldots, 7$

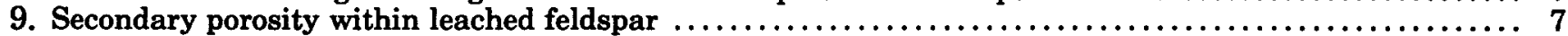

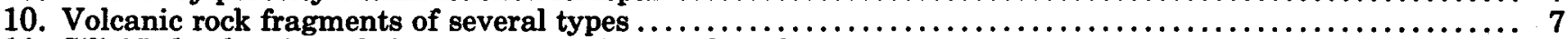

11. Silicified volcanic rock fragment containing relict phenocrysts. $\ldots \ldots \ldots \ldots \ldots \ldots \ldots \ldots \ldots \ldots \ldots \ldots \ldots, 8$

12. Mudstone clast deformed by compaction to produce pseudomatrix $\ldots \ldots \ldots \ldots \ldots \ldots \ldots \ldots \ldots \ldots \ldots \ldots \ldots, 8$

13. Poikilotopic calcite cement and calcite grain replacement $\ldots \ldots \ldots \ldots \ldots \ldots \ldots \ldots \ldots \ldots \ldots \ldots \ldots \ldots \ldots \ldots, 8$

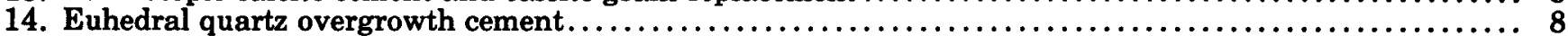

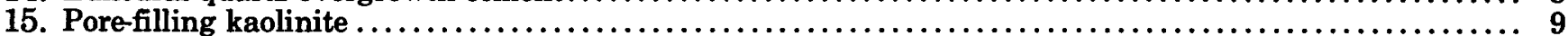

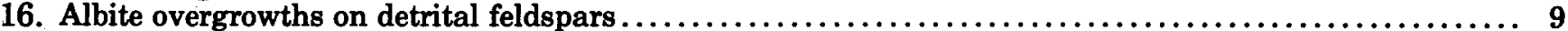

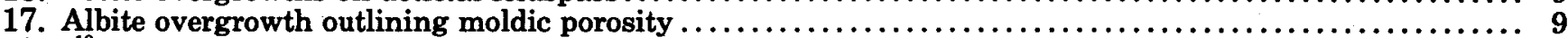

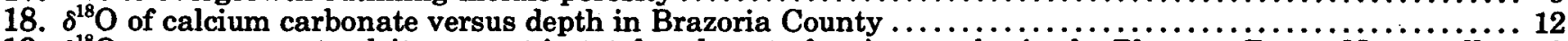

19. $\delta^{18} \mathrm{O}$ versus percent calcite cement in total carbonate for six samples in the Pleasant Bayou No. 1 well $\ldots 13$

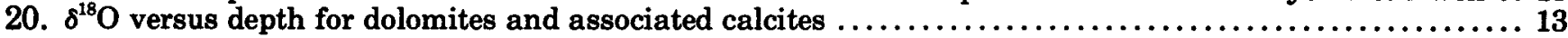




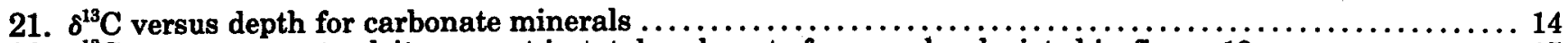

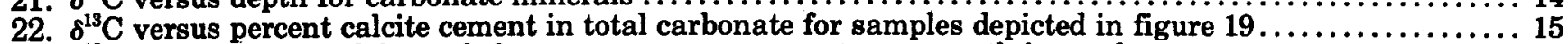

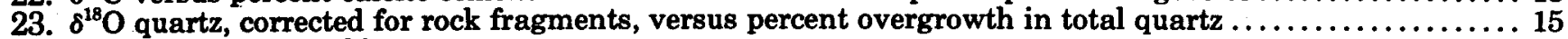

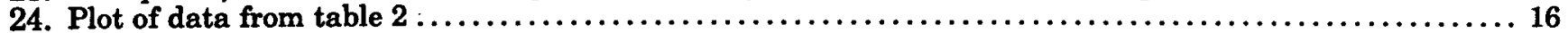

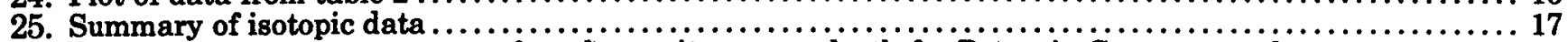

26. Secondary porosity as percent of total porosity versus depth for Brazoria County samples $\ldots \ldots \ldots \ldots \ldots \ldots 17$

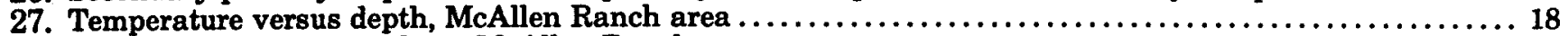

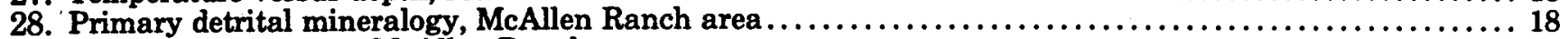

29. Rock fragment types, McAllen Ranch area $\ldots \ldots \ldots \ldots \ldots \ldots \ldots \ldots \ldots \ldots \ldots \ldots \ldots \ldots \ldots \ldots \ldots \ldots \ldots \ldots \ldots \ldots \ldots, 18$

30. Authigenic sphene partly filling a secondary pore in plagioclase $\ldots \ldots \ldots \ldots \ldots \ldots \ldots \ldots \ldots \ldots \ldots \ldots \ldots, \ldots \ldots \ldots$

31. Multiple twinned albite overgrowths on detrital plagioclase $\ldots \ldots \ldots \ldots \ldots \ldots \ldots \ldots \ldots \ldots \ldots \ldots \ldots \ldots \ldots, 20$

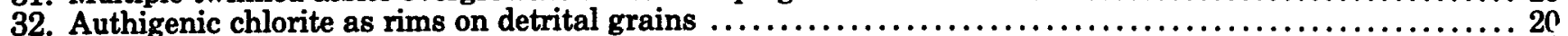

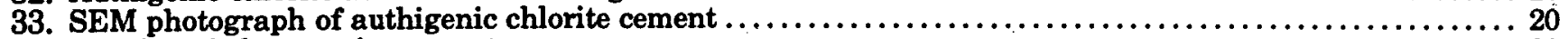

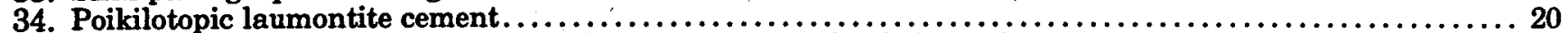

35. Secondary porosity as percent of total porosity versus depth for Hidalgo County samples .............221

36. Oxide trends with depth, Pleasant Bayou No. 1, Brazoria County $\ldots \ldots \ldots \ldots \ldots \ldots \ldots \ldots \ldots \ldots \ldots \ldots \ldots \ldots, 24$

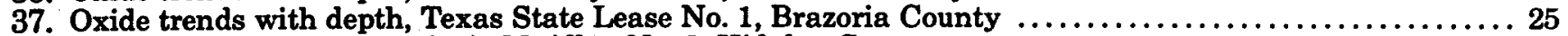

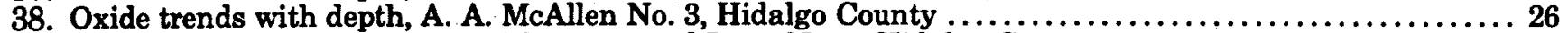

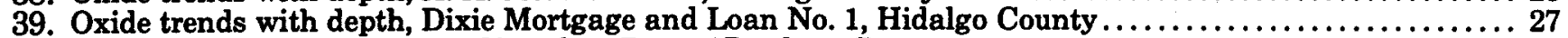

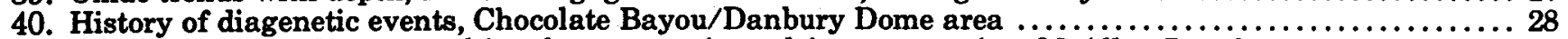

41. Low porosity sandstone resulting from pervasive calcite cementation, McAllen Ranch area ............ 29

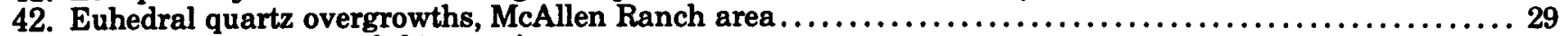

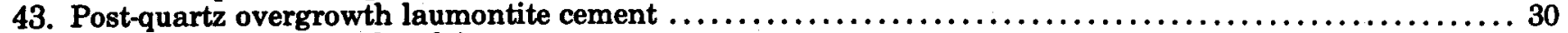

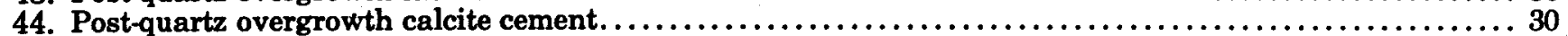

45. History of diagenetic events, McAllen Ranch area $\ldots \ldots \ldots \ldots \ldots \ldots \ldots \ldots \ldots \ldots \ldots \ldots \ldots \ldots \ldots \ldots \ldots \ldots \ldots \ldots, 31$

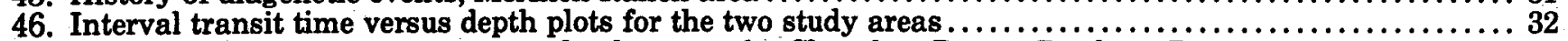

47. Comparison of temperature versus depth curves for Chocolate Bayou/Danbury Dome area and McAllen Ranch area

\section{Text Tables}

1. $\delta^{18} \mathrm{O}$ values for subsurface waters in the Chocolate Bayou Field, Brazoria County, Texas ............ 11

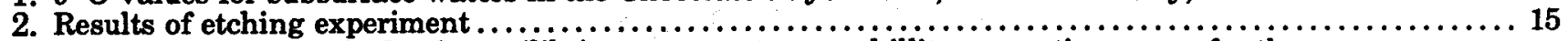

3. Comparison of sample depth, equilibrium temperature, and illite proportion range for the

random to weak order change and the weak to strong order change for each well $\ldots \ldots \ldots \ldots \ldots \ldots \ldots, 23$

4. Characteristics of Chocolate Bayou/Danbury Dome area and McAllen Ranch area................... 30

\section{Appendix Illustrations}

\section{Appendix Figure}

A-1. Relationship between temperature, $\delta^{18} \mathrm{O}_{\mathrm{H} 2 \mathrm{O}}$, and $\delta^{18} \mathrm{O}$ of a mineral precipitated from aqueous solution $\ldots 36$

\section{Appendix Tables}

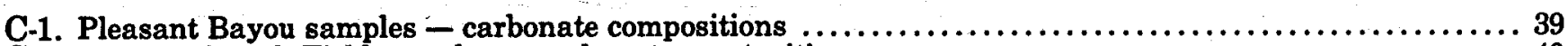

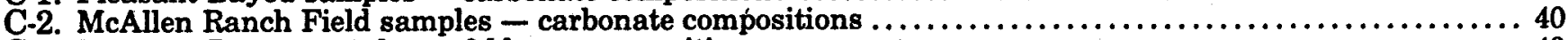

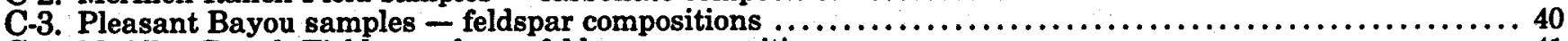

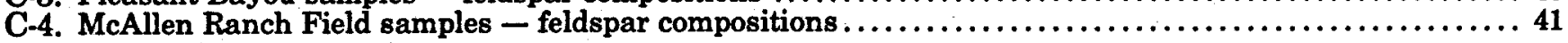




\section{ABSTRACT}

Variable intensity of diagenesis is the factor primarily responsible for contrasting regional reservoir quality of Tertiary sandstones from the upper and lower Texas coast. Detailed comparison of Frio sandstone from the Chocolate Bayou/Danbury Dome area, Brazoria County, and Vicksburg sandstones from the McAllen Ranch Field area, Hidalgo County, reveals that extent of diagenetic modification is most strongly influenced by (1) detrital mineralogy and (2) regional geothermal gradients.

Vicksburg sandstones from the McAllen Ranch Field area are less stable, chemically and mechanically, than Frio sandstones from the Chocolate Bayou/Danbury Dome area. Vicksburg sandstones are mineralogically immature and contain greater proportions of feldspars and rock fragments than do Frio sandstones. The reactive detrital assemblage of Vicksburg sandstones is highly susceptible to diagenetic modification. Susceptibility to modification is enhanced by higher than normal geothermal gradients in the McAllen Ranch Field area. Consolidation of Vicksburg sandstones began at shallower burial depth, and precipitation of authigenic phases (especially calcite) was more pervasive than in Frio sandstones. Moreover, the late-stage episode of ferroan calcite precipitation that occluded most secondary porosity in Vicksburg sandstones did not occur significantly in Frio sandstones. Therefore, the regional reservoir quality of Frio sandstones from Brazoria County is far better than that characterizing Vicksburg sandstones from Hidalgo County, especially at depths suitable for geopressured geothermal energy production.

However, in predicting reservoir quality on a site-specific basis, locally variable factors such as relative proportions of porosity types, pore geometry as related to permeability, and local depositional environment must also be considered. Even in an area of regionally favorable reservoir quality, such local factors can significantly affect reservoir quality and, hence, the geothermal production potential of a specific sandstone unit.

\section{INTRODUCTION}

Two deep subsurface areas of greatly contrasting reservoir quality were identified by Loucks and others (1979) (fig. 1). Deep Frio sandstones in Brazoria County (Upper Texas Gulf Coast) are characterized by abundant secondary porosity and high permeability. In contrast, Vicksburg sandstones in Hidalgo County (Lower Texas Gulf Coast) contain extensive authigenic calcite at all depths examined and only minor secondary porosity. Distribution of sandstone samples from both areas is shown in figure 2. This study identifies the factors responsible for differences in the sequences and intensities of diagenetic events that produced such extreme variations in reservoir quality in these two areas.

A major factor contributing to differences in regional reservoir quality in the two study areas is the difference in detrital mineralogies of the sandstones. The detrital constituents of Vicksburg sandstones in Hidalgo County are chemically and mechanically less stable than those of Frio sandstones in Brazoria County. Superposed upon these contrasting detrital assemblages are differences in regional temperature gradients and depths to the transition from the hydropressured to the geopressured regime. The McAllen Ranch Field area is characterized by higher geothermal gradients and shallower depth to the top of the geopressured zone than is the Chocolate Bayou/Danbury Dome area. Potential differences in bulk mineralogy of associated shales in the two areas may also influence diagenesis and, hence, reservoir quality.

\section{OBJECTIVES}

The overall goal of this study is to expand our understanding of the occurrence and distribution of deep subsurface geothermal reservoirs. Specific objectives are to (1) determine the origin of porosity, with emphasis on secondary leached porosity; (2)define relationships among porosity, permeability, and mineralogy; (3) relate effects of concomitant shale diagenesis to cementation and leaching in adjacent sandstones; and (4) integrate conclusions from objectives 1 through 3 into geothermal resource assessment studies in Texas to aid in identification of areas favorable for geopressured geothermal exploration. 


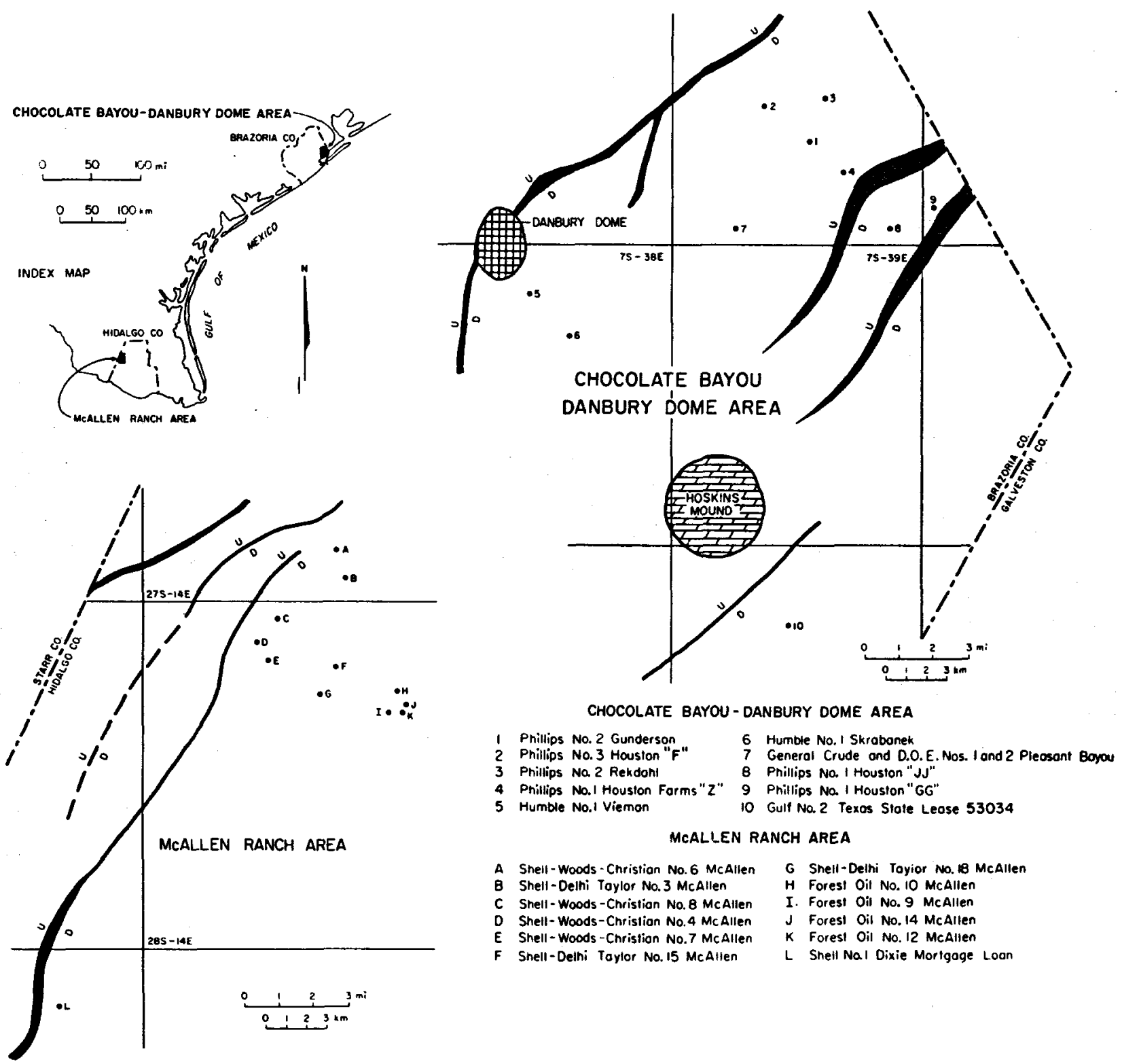

Figure 1. Location of samples used in this study. Map of Chocolate Bayou/Danbury Dome area from Bebout and others (1978). Map of McAllen Ranch area modified from Berg and others (1979).

\section{ANALYSIS OF FRIO SANDSTONES, CHOCOLATE BAYOU/DANBURY DOME AREA, BRAZORIA COUNTY}

\section{Depositional Systems and Structure}

Frio sediments in the Chocolate Bayou/Danbury Dome area were deposited as a series of slightly elongate deltas on the downdip side of a large growth fault in a salt withdrawal basin (Bebout and others, 1978). Major sand depocenters in the upper Frio migrated updip, resulting in mud-dominated distal delta and shelf deposits overlying the older deltaic sandstones. Thus, sandstones are most abundant in the lower part of the section, although overall they are volumetrically minor, relative to the surrounding shales (Bebout and others, 1978).

Sediments of the ancestral Gulf of Mexico Basin were deposited on a trailing plate margin during Tertiary time. The ancestral Gulf of Mexico Basin subsided rapidly, and uplift was restricted to areas of upwardmoving salt domes and ridges. Salt domes, growth faults with offsets ranging from a few feet to over 4,000 $\mathrm{ft}(1,220 \mathrm{~m}$ ) (fig. 3), and associated rollover anticlines constitute the major geologic structures. Faulting was contemporaneous with deposition; growth faults formed partly in response to loading of sand units on soft, water-saturated muds (Bruce, 1973). Sands subsided along the faults, resulting in thick sand sections on the downthrown sides. Salt dome growth in the upper Texas coast area was synchronous with deposition of the lower part of the section and with faulting (Bebout and others, 1978).

\section{External Controls on Reservoir Quality}

The external parameters that influence regional reservoir quality are fluid pressure gradient and resultant basinal hydrology, geothermal gradient, and pore fluid chemistry. 


\section{CORE DISTRIBUTION BY DEPTH AND WELL}

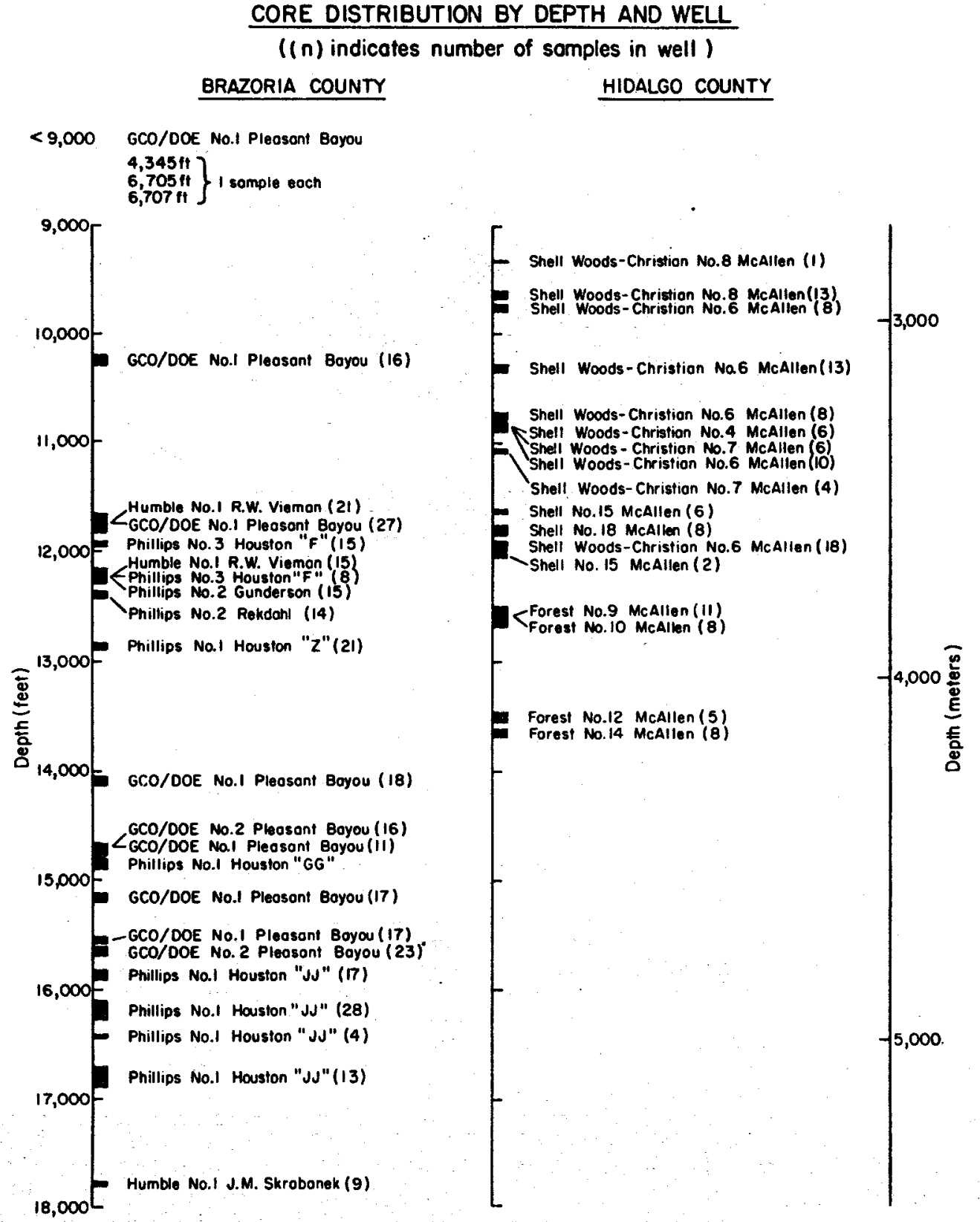

Figure 2. Sample distribution with depth.

\section{Fluid Pressure Gradient}

Pore fluids in the Gulf Coast are divided into two hydrologic regimes, hydropressure and geopressure. In the hydropressure zone, the pressure gradient is 0.465 $\mathrm{psi} / \mathrm{ft}$ (normal hydrostatic), and rocks are under lithostatic pressure of approximately $1.0 \mathrm{psi} / \mathrm{ft}$. In the "soft" geopressure zone (pressure gradient 0.465 to 0.7 $\mathrm{psi} / \mathrm{ft}$ ) the pore fluid supports part of the overburden load. Thus, the effective pressure on the rocks is less than the lithostatic pressure. At a pressure gradient of $0.7 \mathrm{psi} / \mathrm{ft}$, the zone of "hard" geopressure is encountered. The $0.7 \mathrm{psi} / \mathrm{ft}$ value was chosen to define the top of the "hard" geopressure regime because it is at this value that resistivities increase dramatically. Thus, this zone can easily be picked from electric logs.
In the Chocolate Bayou/Danbury Dome area the top of the "hard" geopressure zone occurs between 8,000 and $12,000 \mathrm{ft}(2,440$ and $3,660 \mathrm{~m})$.

Geopressuring effects influence the fluid flow system. As the near-surface sediments compact, water is squeezed from the muds and sands and will ordinarily migrate updip out of the system. However, if the migration path is blocked, fluid escape is impeded. Over long periods of time, however, fluid will migrate from the geopressured zone to lower pressured areas because no sedimentary rock is totally impervious. Fluids may also flow out of the geopressured zone along faults (Jones, 1975). The faults may be areas of persistent local leakage or they may periodically expel fluids as pressure builds up. In the Gulf Coast area, geopressure can occur within a few thousand feet of the surface 


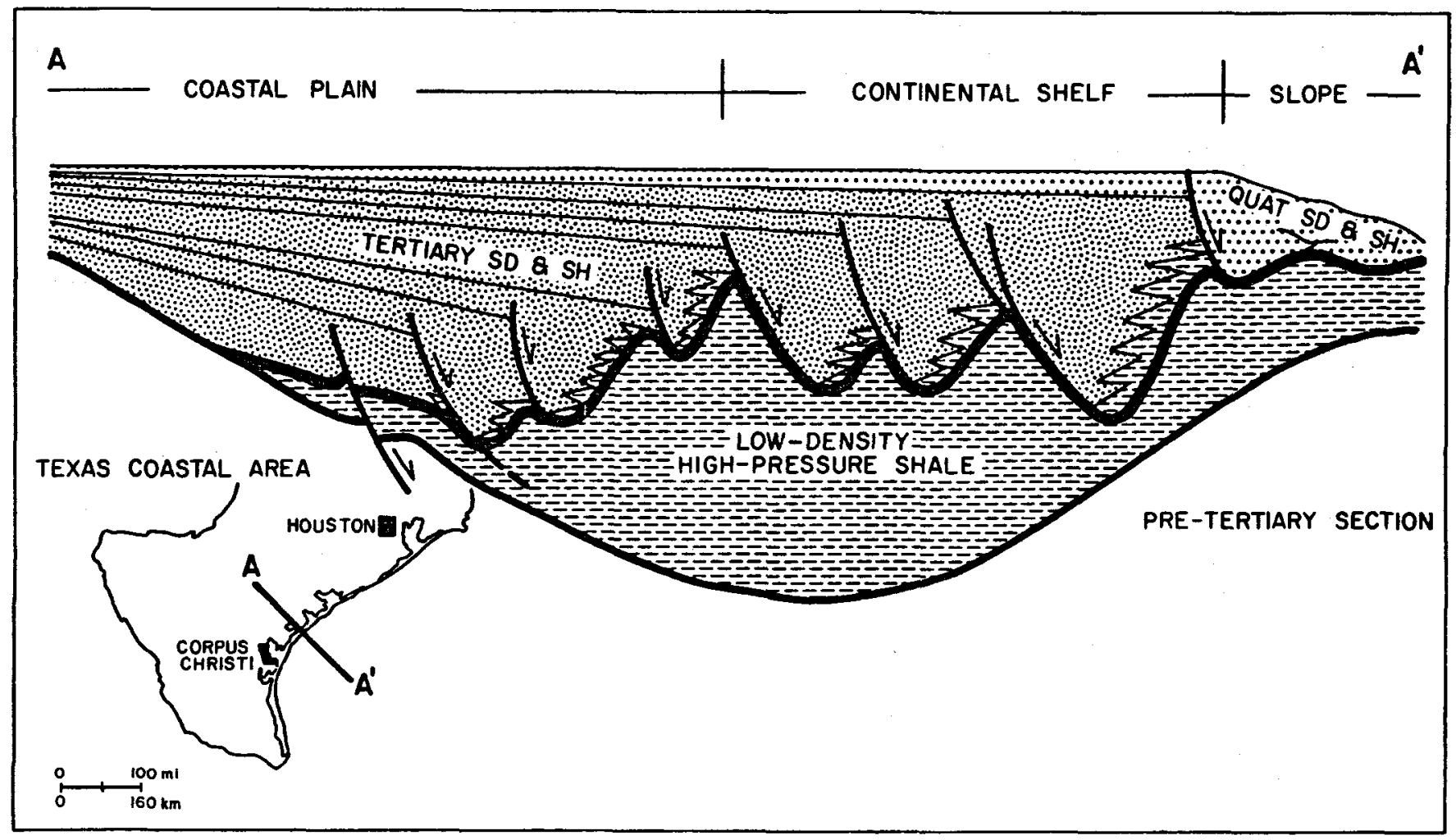

Figure 3. Depositional style of Tertiary strata along the Texas coast. From Bruce (1973).

(Schmidt, 1973; Magara, 1975). Once geopressured, sediments tend to remain so throughout their burial history (Bonham, 1980).

Fluids flow most readily through permeable units to areas of lower pressure, which are generally shallower in the section. Therefore, the distribution of sands and sandstones defines the major fluid flow path in the section. However, fluids also flow through shales but at diminished rates as a result of low permeabilities $\left(10^{-6}\right.$ md; fig. 9-10 in Magara, 1978). Significant volumes of fluid may migrate through shales, given geologically significant periods of time. Also, if shales are hydrofractured at depth, fluids may flow through them more easily (Sharp, 1980).

\section{Thermal Gradient}

The temperature gradient for Brazoria County is not constant with depth (fig. 4). Changes in the gradient are related to the top of geopressure and possibly to lithologic discontinuities (Lewis and Rose, 1970). Heat flow within a finite area can be considered constant and is defined as

$Q=\left(K_{h} / Z\right) A \Delta T$

where: $K_{h}=$ thermal conductivity,

$\mathrm{A}=$ cross-sectional area perpendicular to heat flow, and

$\Delta \mathbf{T}=$ temperature change across thickness Z.

From this relationship it is apparent that $K_{h}$ and $\Delta T$ are inversely related; that is, if $K_{h}$ decreases, $\Delta T$ must increase proportionally to maintain constant $Q$. Within the geopressured zone, rocks are under less than lithostatic pressure, and unless totally cemented, are more porous (undercompacted) than equivalent rocks in the hydropressured section. Because they are more porous, geopressured units contain more water with a thermal conductivity that is only about one-third that of average sedimentary rocks. Therefore, within the geopressure zone, thermal conductivity is lower than in the hydropressure zone, so the thermal gradient $(\Delta T)$ must increase to keep heat flow constant. The temperature gradient plot for the Chocolate Bayou/Danbury Dome area shows a break in slope at the top of the "hard" geopressure zone $(0.7 \mathrm{psi} / \mathrm{ft})$. Above "hard" geopressure, the geothermal gradient is $1.35^{\circ} \mathrm{F} / 100 \mathrm{ft}$, and it increases to $2.49^{\circ} \mathrm{F} / 100 \mathrm{ft}$ within the "hard" geopressure regime. This temperature gradient inflection also coincides with the lithologic boundary between Oligocene sands and overlying Miocene shales.

\section{Pore Fluid Chemistry}

Controls on pore fluid chemistry in Brazoria County are not well understood. Kharaka and others (1977b, 1980) thought that waters contained in Gulf Coast Tertiary sediments represent connate waters trapped by rapid subsidence. Subsidence in the Gulf Coast, especially immediately after deposition, was rapid. In addition, the low-lying coastal topography of the region generally precludes significant meteoric recharge. Thus, a connate-water hypothesis for these rocks is plausible. In any case, the pore waters of the sandbearing intervals of the study area were highly modified after burial by reaction with the enclosing sediments at temperatures up to $180^{\circ} \mathrm{C}\left(360^{\circ} \mathrm{F}\right)$ and possibly by filtering through micropore systems in shales, as outlined for other basins by Graf and others (1965) and Hitchon and Friedman (1969). 


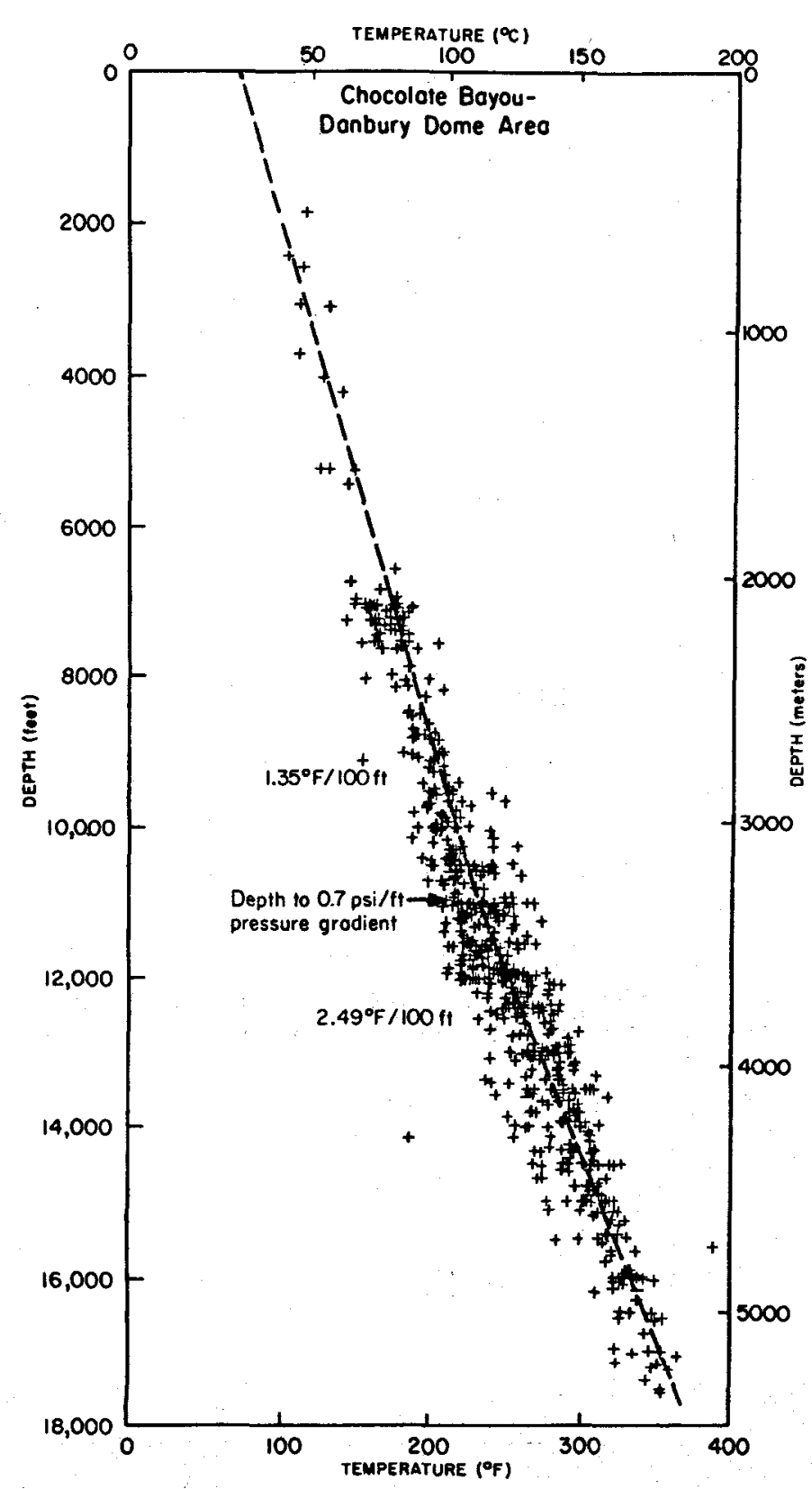

Figure 4. Temperature versus depth, Brazoria County, Texas.

Several investigators have compared salinities in the geopressured and hydropressured zones. Most have reported that salinities decrease below the top of geopressure (Dickey and others, 1972; Schmidt, 1973). Gregory and Backus (1980) compiled well log data indicating that salinities in Brazoria County initially decrease below the top of geopressure and then become erratic, the values in the deeper waters being both above and below salinities in the hydropressured zone (fig. 5). Kharaka and others (1980) analyzed waters in Chocolate Bayou Field and found that salinities increase in the geopressured zone.

\section{Detrital Mineralogy and Texture}

Three hundred fifty-four Frio thin sections from Brazoria County, Texas, were point counted (200 points per section) to determine detrital and authigenic compositions of the sandstones. Of the-total thin sections, 145 are samples from the two Pleasant Bayou geothermal test wells. Data from these samples are included in the Brazoria County data base from which generalizations regarding Frio sandstones were drawn. However, the Pleasant Bayou test well sites were selected on the basis of their particularly favorable geothermal potential. Therefore, certain physical characteristics of samples from these wells are predictably atypical. A later section of this report (p. 26) will address significant differences in Pleasant Bayou samples relative to typical Frio sandstones from Brazoria County.

Samples selected for petrographic study are dominantly medium to very fine grained, moderately to well-sorted sandstones. Minor lithologies include muddy, very fine grained sandstones and siltstones. Although the detrital mineralogy is quite simple (most framework grains are quartz, plagioclase, or volcanic rock fragments) the relative proportions of these constituents, especially quartz, vary widely. Sandstones are classified according to Folk (1974) (fig. 6). Most sandstones are lithic arkoses and feldspathic litharenites; however, a significant number contain sufficient quartz to be subarkoses and sublitharenites (fig. 7). Detailed descriptions of the major detrital constituents follow.

\section{Quartz}

Volcanic, metamorphic, reworked sedimentary, and "common" quartz are all present in Frio sandstones. "Common" (unstrained) quartz is by far the most important volumetrically, but this variety has no unique genetic association. Volcanic quartz, with straight extinction and well-developed crystal faces, occurs in minor amounts and was most likely derived from volcanic terrain in West Texas. Stretched metamorphic quartz grains and reworked sedimentary quartz, identified by transported overgrowths, are also present in minor quantities; the source of these grains is unclear.

\section{Feldspar}

Plagioclase is the dominant feldspar variety. Most grains are untwinned and show varying degrees and types of alteration, including vacuolization, sericitization, replacement by calcite or kaolinite, and leaching. Amaranth stain, used to aid in plagioclase identification (Laniz and others, 1964), does not react well with the typical plagioclase of these samples, which indicates low calcium content. Electron microprobe analysis of a number of detrital plagioclase grains from Pleasant Bayou samples (Appendix C) confirms that they are albite. However, polysynthetic twinning is usually present in primary albite. It seems reasonable to assume that the plagioclase originally had an intermediate composition that was subsequently modified through extensive albitization. Boles (1979) suggests that such albitization in Frio sandstones may occur in the temperature range of $100^{\circ}$ to $120^{\circ} \mathrm{C}\left(212^{\circ}\right.$ to $\left.250^{\circ} \mathrm{F}\right)$. This corresponds to burial depth of approximately 10,000 to $12,000 \mathrm{ft}(3,050$ to 3,660 $m$ ) in the Pleasant Bayou/Danbury Dome area.

Minor quantities of detrital potassium feldspar are present in Frio sandstones. Many grains are microcline, 
characterized by grid twinning and a relatively fresh appearance compared to detrital plagioclase. Other grains exhibit textures suggestive of albitization (fig. 8). Both plagioclase and potassium feldspar are susceptible to leaching, and abundant leached grains contribute substantially to secondary porosity (fig. 9).

\section{Rock Fragments}

Volcanic rock fragments (VRF's) are the dominant variety (fig. 10). Compositionally, they reflect a felsic to intermediate volcanic source; VRF"s are primarily rhyolites and trachytes (Lindquist, 1977). Some fragments exhibit distinctive volcanic features such as well-developed phenocrysts, whereas in other fragments alteration to clays has obscured, and in some cases destroyed, original textures. Still other VRF's have altered to microcrystalline quartz. In fragments where relict phenocrysts are identifiable, a volcanic source can be assigned with certainty (fig. 11). However, many clasts are indistinguishable from chert fragments eroded from carbonate source rocks. We infer a volcanic source for these silicified fragments.

Mudstone and shale clasts occur less commonly than VRF's in Frio sandstones. However, these argillaceous rock fragments, along with clay-altered VRF's, are significant because during compaction they can be extensively deformed to produce "pseudomatrix" (fig. 12) (Dickinson, 1970). Pseudomatrix, where abundant, is an effective inhibitor of permeability, and thus may restrict diagenetic processes. Other sedimentary, lowgrade metamorphic, and plutonic rock fragments are minor.

\section{Matrix}

Depositional matrix is common in Frio sandstones. This detrital material, which is finer than $20 \mu \mathrm{m}$ and is composed largely of clays, obstructs permeability. As in rocks containing abundant pseudomatrix, diagenesis in matrix-rich rocks is severely restricted. Because of its low permeability, matrix tends to inhibit both cementation and development of secondary porosity. In addition to depositional matrix, some samples contain a "cherty matrix" believed to be composed of diagenetically modified detrital material and authigenic quartz. A similar material was described by Dapples (1972), who also interpreted it as a highly altered and recrystallized depositional matrix.

\section{Diagenetic Modification}

Diagenesis encompasses postdepositional modification of sediments, precipitation of authigenic minerals (cementation), chemical alteration of detrital constituents (replacement), and dissolution of detrital and/or authigenic constituents (leaching). At the upper limits of temperature and pressure, diagenesis merges with low-grade metamorphism.

\section{Authigenic Minerals}

Major authigenic phases identified in Frio samples from Brazoria County include multiple varieties of carbonate, quartz, and kaolinite. Minor phases are feldspars, chlorite, zeolite, and unidentified authigenic clays present as rims and coats on detrital grains.

\section{Carbonates}

Calcite is the dominant carbonate. Ferroan ( Febearing) and non-ferroan calcite occur as sparry and

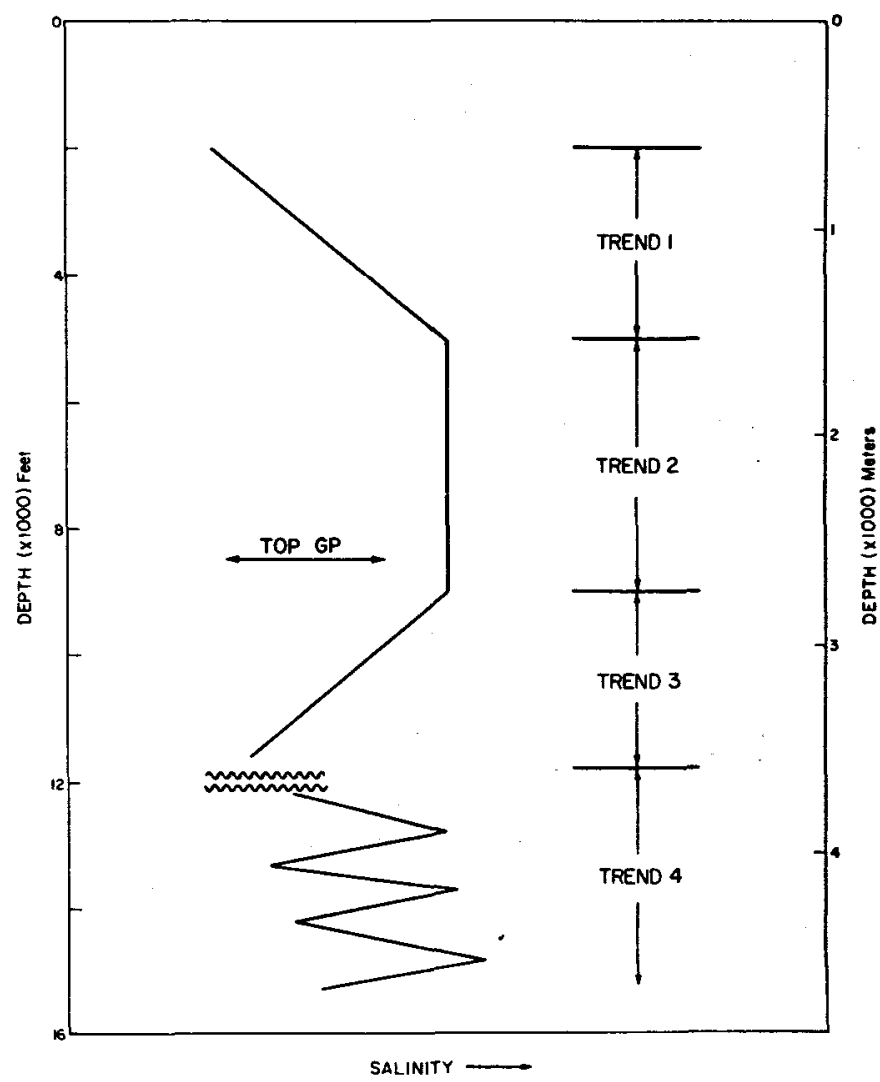

Figure 5. Generalized salinity trends, Brazoria County, Texas. From Gregory and Backus (1980).

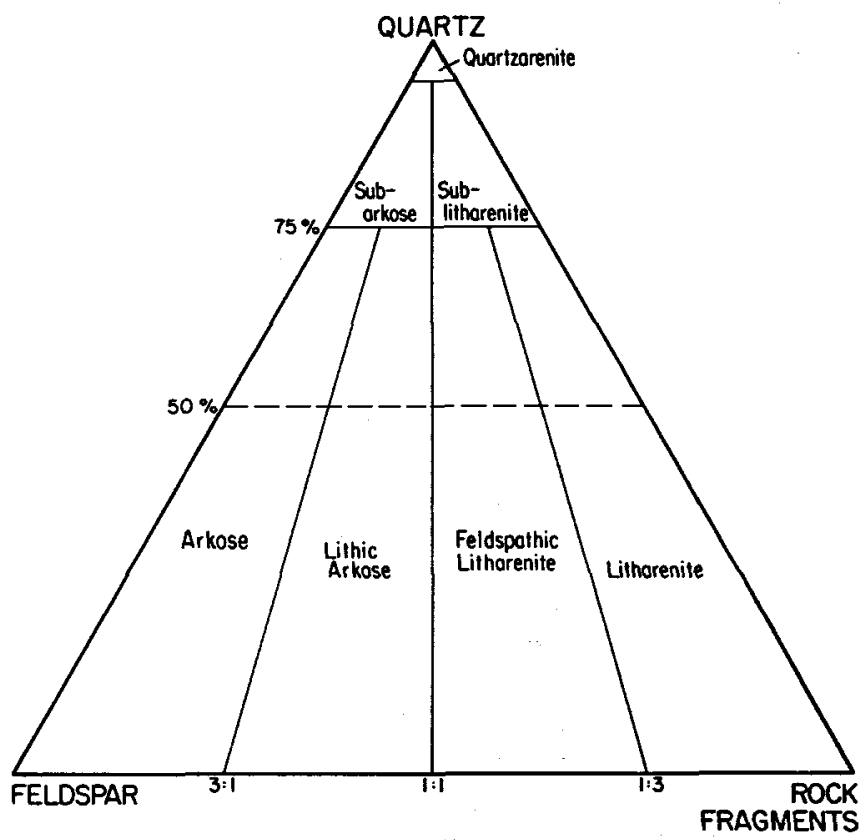

Figure 6. Sandstone classification of Folk (1974).

poikilotopic cements; the more abundant non-ferroan variety also replaces grains (especially plagioclase and VRF's) (fig. 13). Calcite cements are present in samples from all depth intervals studied. Dolomite, characterized by undulose extinction and curved crystal faces ("baroque" dolomite, after Folk and 


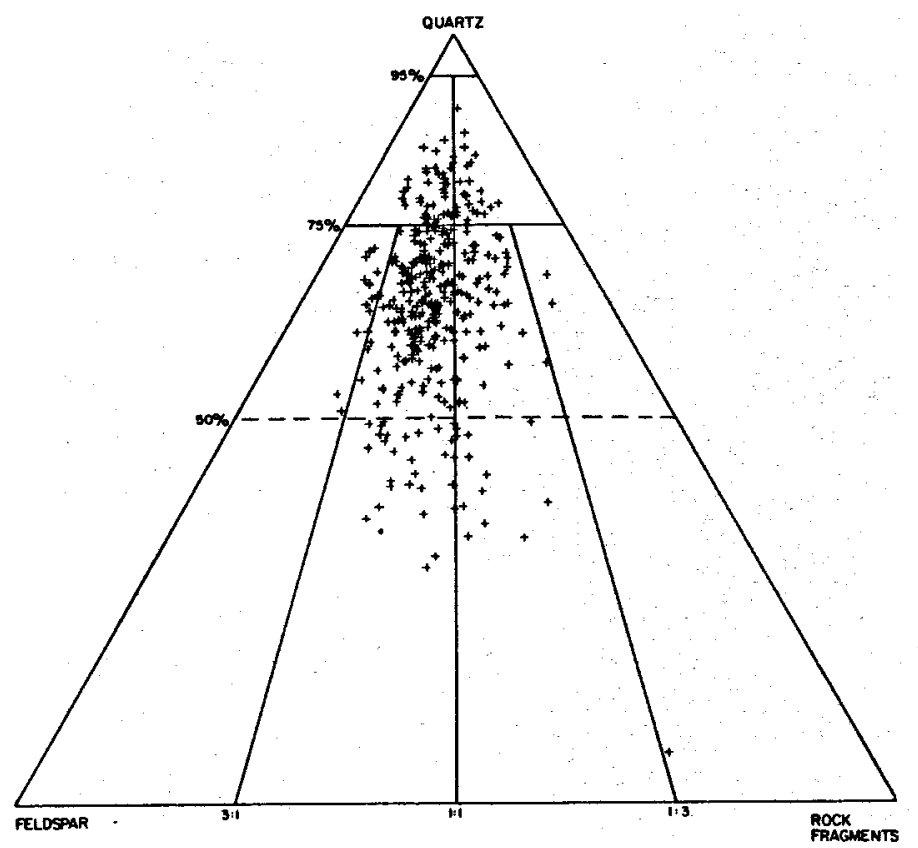

Figure 7. Primary detrital mineralogy, Chocolate Bayou/Danbury Dome area.

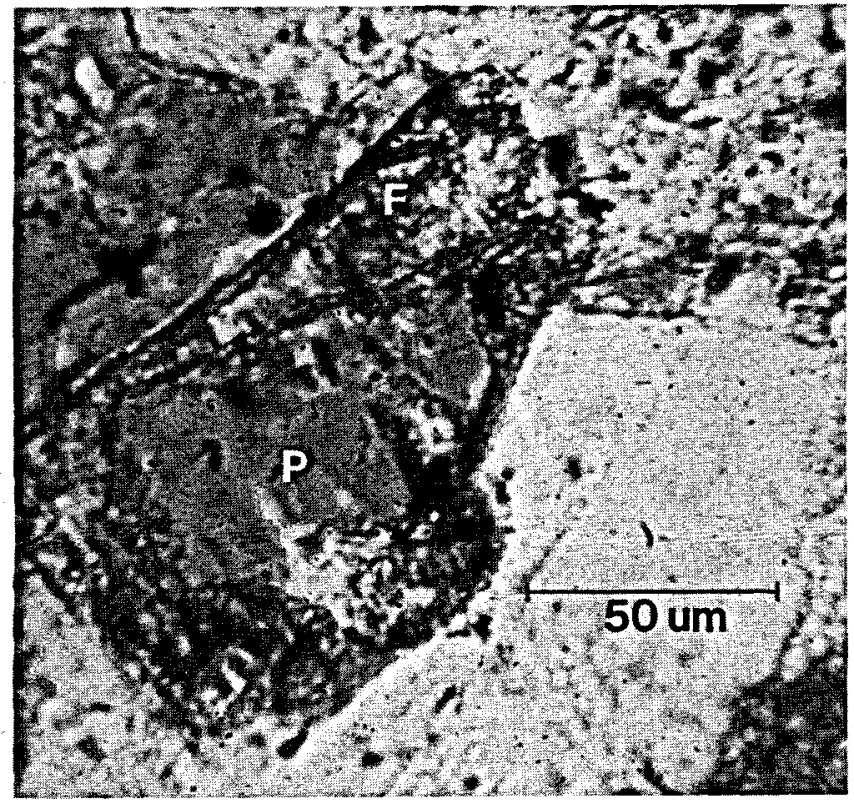

Figure 9. Secondary porosity (P) within leached feldspar (F). Plane polarized light.

Assereto, 1974), is present as sparry and poikilotopic cement in a few samples; however, it is considerably less abundant and widespread than calcite. Euhedral ferroan dolomite (or ankerite) rhombs were also observed in a small number of samples. Leaching of authigenic carbonates is responsible for much of the secondary porosity developed in Frio sandstones.

\section{Quartz}

Authigenic quartz formed as overgrowths on detrital quartz grains. Such overgrowths are abundant in samples from the deep burial interval (greater than

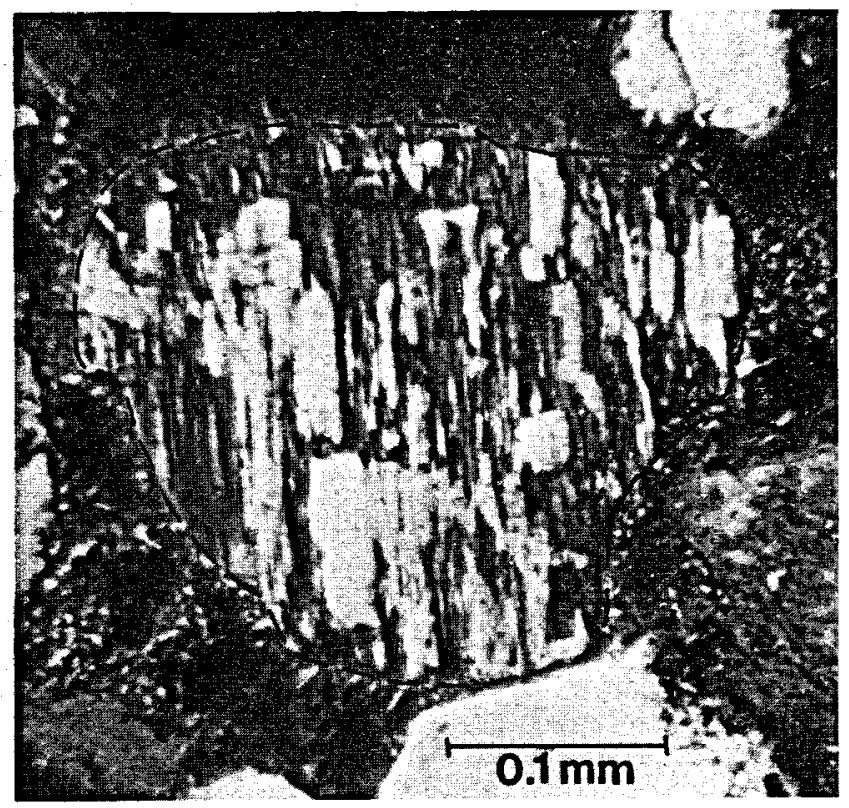

Figure 8. Chessboard twinning resulting from albitization of potassium feldspar (outlined). Crossed polars.

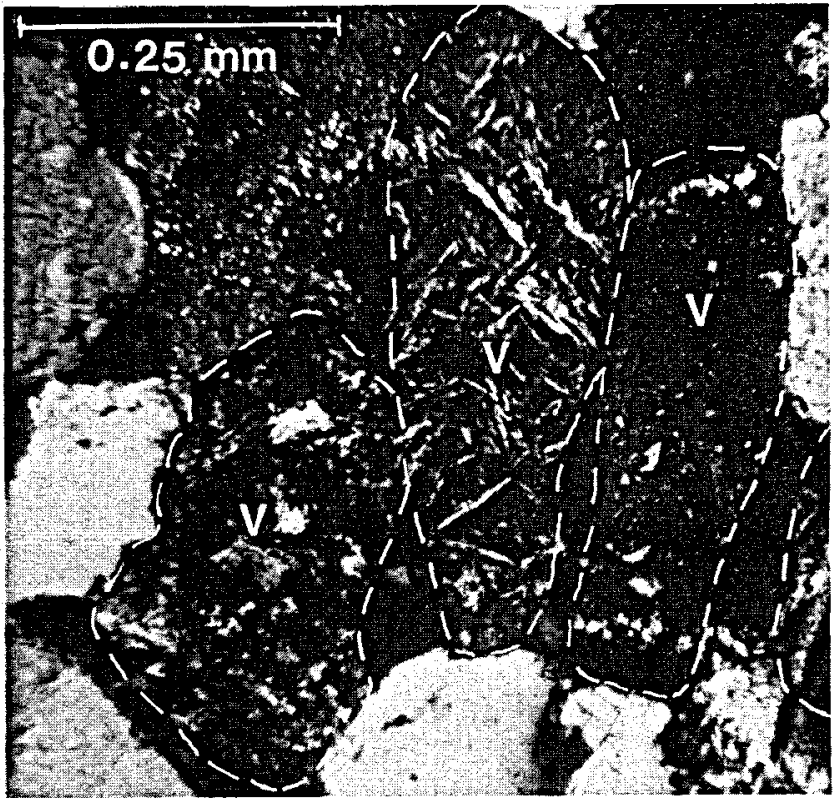

Figure 10. Volcanic rock fragments (V) of several types. Crossed polars.

$11,000 \mathrm{ft}[3,550 \mathrm{~m}])$ defined by Loucks and others (1979). Quartz overgrowths commonly exhibit euhedral terminations where they grew into pores (fig. 14). The abundance of quartz overgrowths shows a weak correlation with detrital quartz abundance.

\section{Kaolinite}

Authigenic kaolinite is abundant in sandstones to depths in excess of $17,700 \mathrm{ft}(5,395 \mathrm{~m})$. Most kaolinite occurs as a pore-filling cement with vermicular habit (fig. 15), and individual booklets up to several hundred microns in length are common. Kaolinite has also been 


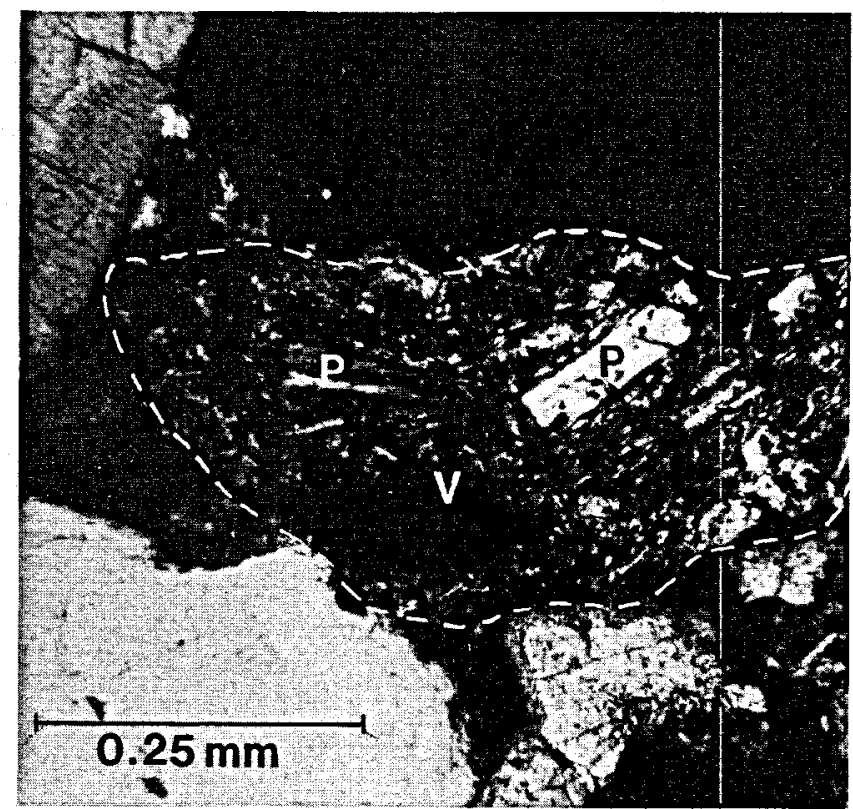

Figure 11. Silicified volcanic rock fragment (V) containing relict phenocrysts $(P)$. Crossed polars.

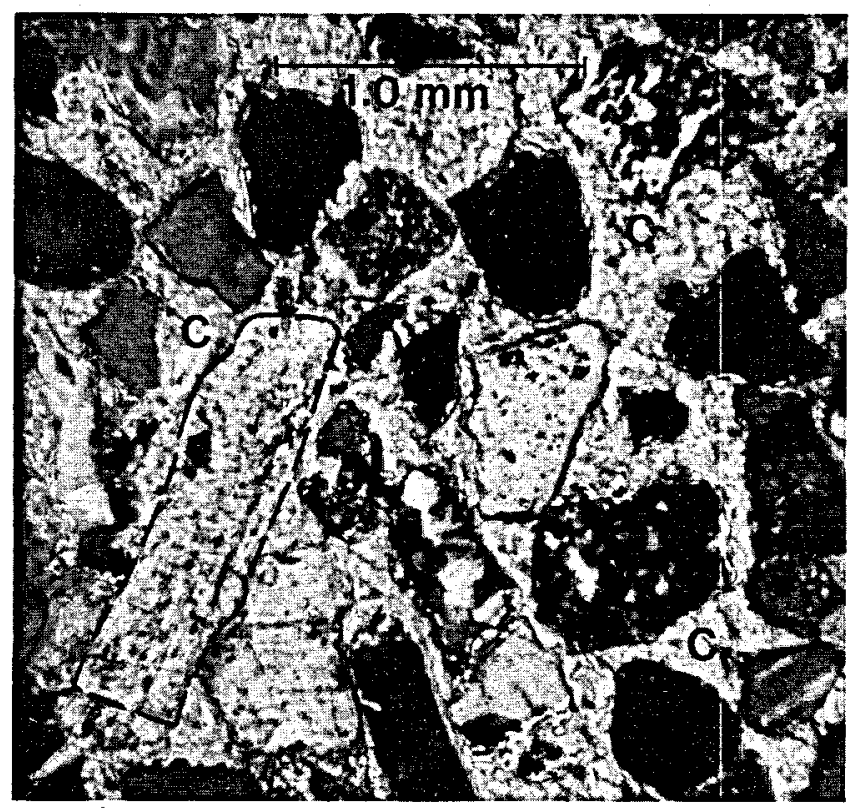

Figure 13. Poikilotopic calcite cement (C) and calcite grain replacement (outlined). Crossed polars.

observed as a replacement mineral, especially associated with plagioclase. Some detrital grains were totally replaced, and in these instances the kaolinite commonly grew outward from the grain surface into available pore space. Rocks containing abundant authigenic kaolinite are generally not of reservoir quality: they have moderate porosities but very low permeabilities. The porosity present is largely microporosity (pore aperture radii less than $0.5 \mu \mathrm{m}$ ) existing between individual clay flakes. This type of porosity does not contribute significantly to permeability. Authigenic kaolinite can create fluid

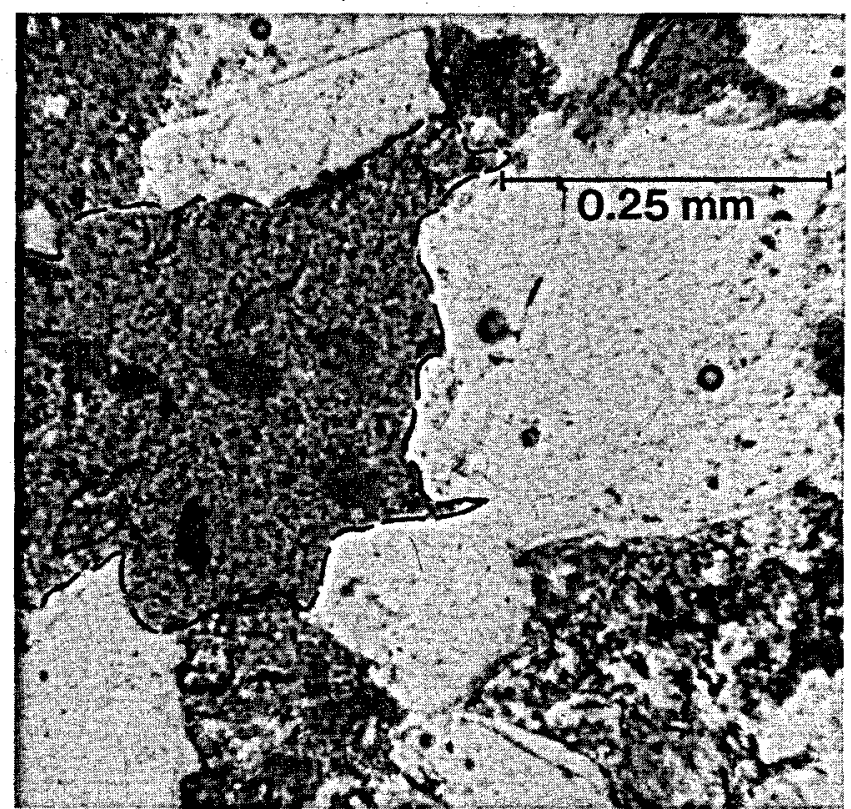

Figure 12. Mudstone clast (outlined) deformed by compaction to produce pseudomatrix. Plane polarized light.

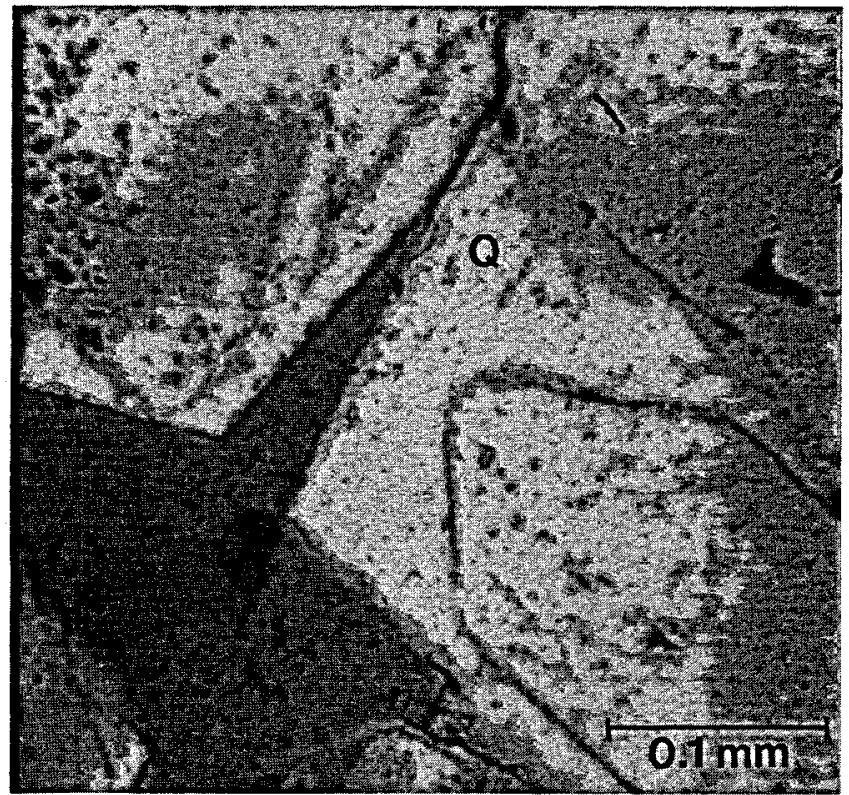

Figure 14. Euhedral quartz overgrowth cement (Q). Plane polarized light.

production problems because its delicate structure makes authigenic kaolinite very fragile(Pittman, 1979). Dislodged clay flakes can further obstruct permeability.

\section{Minor Authigenic Minerals}

Authigenic feldspars, chlorite, zeolite, and clay rims and coats were identified in trace amounts in some Frio sandstone samples. Authigenic feldspars are present as overgrowths on detrital feldspar grains (fig. 16). Overgrowths are most commonly albite, although rare potassium feldspar overgrowths are also present. Albite overgrowths are occasionally twinned. Frequently, 


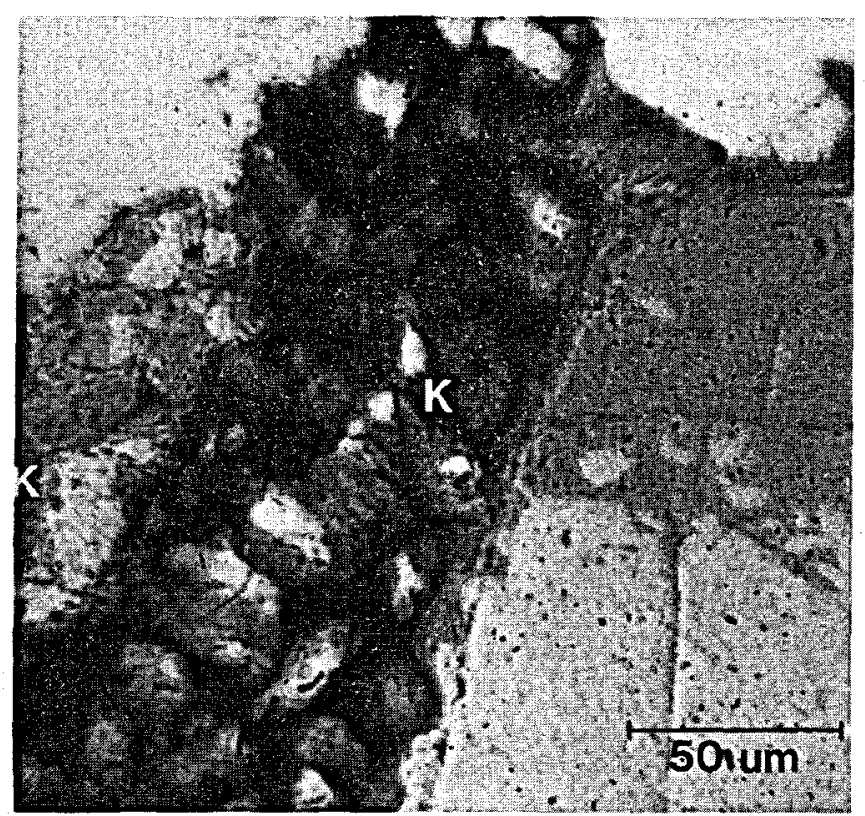

Figure 15. Pore-filling kaolinite (K). Crossed polars.

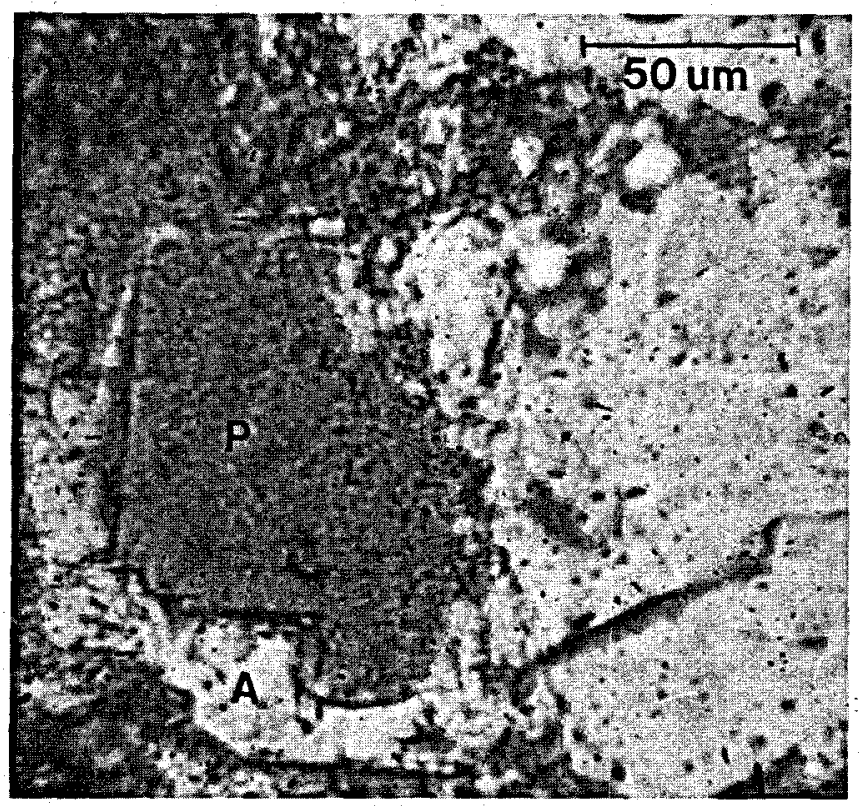

Figure 17. Albite overgrowth (A) outlining moldic porosity (P).

fresh feldspar overgrowths rim leached detrital grains, and where leaching was extensive the overgrowth may outline the moldic porosity (fig. 17). Authigenic feldspars are more chemically stable than their detrital counterparts and thus have greater resistance to leaching because they formed under conditions more closely approximating the environment in which they are found today.

Chlorite is another trace authigenic constituent in Frio samples. It is occasionally found as an alteration product of VRF's and, rarely, as a minor cement. Likewise, the zeolite, laumontite, was identified in a few samples. Laumontite apparently formed as a

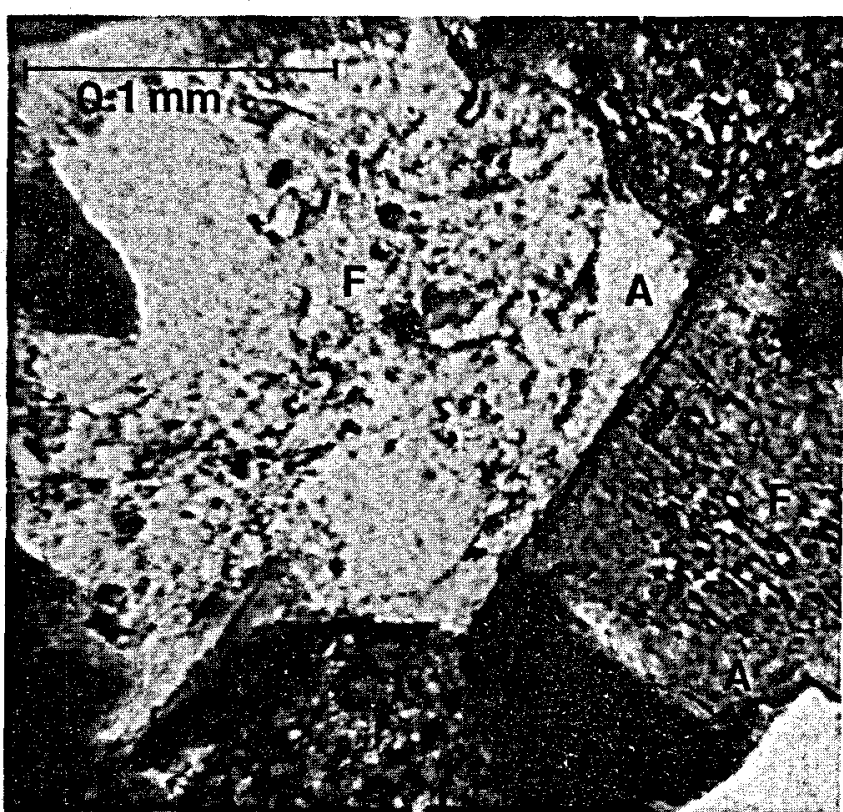

Figure 16. Albite overgrowths (A) on detrital feldspars (F). Crossed polars.

poikilotopic cement; however, only a few fragmental patches survived leaching.

Clay coats and rims are diagenetic features that formed on detrital grains very early in the sandstone consolidation sequence. In clay rims, the individual clay flakes are oriented perpendicular to the grain surface, whereas clay coats are formed by clay flakes oriented tangential to the grain surface. Clay coats are more abundant than clay rims and often define the boundary between detrital quartz grains and quartz overgrowths.

\section{Porosity Types}

Porosity may be broadly subdivided into two categories based primarily on average pore-throat diameter. "Microporosity" has an average pore-throat diameter of less than $1.0 \mu \mathrm{m}$, whereas the average porethroat diameter of "macroporosity" is greater than $1.0 \mu \mathrm{m}$.

Microporosity is impossible to quantify petrographically because of its small size and its intimate association with authigenic clays, clay matrix, and fine-grained, argillaceous rock fragments. This porosity type is dominant in lithologies containing these constituents. Microporosity does not contribute measurably to permeability but is responsible for much of the irreducible water saturation in sandstones (Pittman, 1979).

In contrast, macroporosity is easily quantifiable in thin section, and it contributes most significantly to permeability. This porosity type is dominant in the coarser grained, matrix-poor sandstones examined. Macroporosity may be present in sandstones in one or more of the following forms: (1) primary intergranular, which is that part of the depositional porosity between detrital grains remaining at any subsequent stage of diagenesis; (2) secondary (dissolution), which is either intergranular (porosity resulting from dissolution of cements) or intragranular (porosity resulting from 
dissolution of framework grains and/or replacement minerals); and (3) hybrid, or porosity that cannot be classified as completely primary or secondary. Many oversized pores are probably hybrid; that is, they may represent primary pores that have been enlarged by the secondary process of dissolution.

The dominant type of porosity occurring in matrixfree sandstones of the shallow subsurface (to depths of approximately $6,000 \mathrm{ft}[1,830 \mathrm{~m}]$ in Brazoria County) is primary intergranular porosity. However, the major types of porosity encountered at depths suitable for geopressured geothermal energy production are microporosity and secondary porosity. Secondary porosity is extensively developed in matrix-poor, deep Frio sandstones. These rocks are the best potential geothermal reservoirs. Much of the primary intergranular porosity was occluded by cement before the sandstones reached the "soft" geopressured zone $(0.465 \mathrm{psi} / \mathrm{ft}$ ) (Loucks and others, 1979); therefore, permeability in the geopressured zone is more dependent on secondary porosity.

\section{Minor Element Chemistry}

Electron microprobe analyses were conducted on selected samples from GCO/DOE Nos. 1 and 2 Pleasant Bayou, Brazoria County, in order to supplement petrographic data. Our major objectives were preliminary quantification of variations in the minor element chemistry of authigenic carbonate phases and determination of detrital feldspar compositions. Appendix $\mathrm{C}$ presents microprobe data as weight percent of oxides for carbonates and feldspars from Pleasant Bayou.

Although we were not able to analyze enough carbonate samples to identify potentially systematic variations in composition with depth, these analyses provide a preliminary estimate of the range of possible compositional variations and confirm the existence of multiple generations of authigenic carbonates.

Authigenic carbonates in samples from GCO/DOE Nos. 1 and 2 from the following depths were analyzed for $\mathrm{MgO}, \mathrm{SrO}, \mathrm{CaO}, \mathrm{MnO}$, and $\mathrm{FeO}$ by electron microprobe: $4,345 \mathrm{ft}(1,324 \mathrm{~m}) ; 11,773 \mathrm{ft}(3,589 \mathrm{~m}) ; 14,685$ $\mathrm{ft}(4,476 \mathrm{~m}) ; 15,162 \mathrm{ft}(4,621 \mathrm{~m}) ;$ and $15,173 \mathrm{ft}(4,625 \mathrm{~m})$.

All authigenic carbonates analyzed are calcite; however, in some samples, the poikilotopic cement contains variable amounts of $\mathrm{FeO}$, up to approximately 3 percent. $\mathrm{MnO}$ content of cements is also variable, ranging from $<0.1$ to approximately 1.5 percent. $\mathrm{MgO}$ content is somewhat less variable than either $\mathrm{FeO}$ or $\mathrm{MnO}$ and does not exceed 0.6 percent in any analysis. $\mathrm{SrO}$ is a minor component in the calcite cements.

Microprobe traverses across several areas of sparry and poikilotopic calcite detected no trace-element zoning within the cements. The probe analyses do, however, confirm the existence of multiple, compositionally distinct generations of calcite. The presence of ferroan and non-ferroan calcite was known from petrographic analysis of thin sections stained with alizarin red-S and potassium ferricyanide (technique of Lindholm and Finkelman, 1972). Unfortunately, such staining neither quantitatively reflects subtle variations in iron concentrations, nor indicates the presence of other ions substituting for calcium (for example, $\mathbf{M n}^{+2}, \mathbf{M g}^{+2}$, and so on). For example, the shallowest Pleasant Bayou sample analyzed (from 4,345 ft [1,324 m]) contains a highly ferroan (up to approximately 3 percent) poikilotopic calcite cement and non-ferroan calcite grain replacements and foraminifers. In a deeper sample (from 11,773 ft [3,589 m]) the poikilotopic cement and grain replacements share a common chemical composition distinctly different from either of the calcite compositions in the sample from $4,345 \mathrm{ft}(1,324$ $\mathrm{m})$; these deeper calcites contain only about one-third the $\mathrm{FeO}$, but are substantially enriched in $\mathrm{MnO}$ (containing up to approximately 1.4 percent) relative to the shallower calcites. Although the deeper calcites are compositionally distinct from the shallow ferroan calcite, their slight chemical differences could not have been detected in stained thin sections.

Another distinctive poikilotopic calcite composition occurs in the sample from $14,685 \mathrm{ft}(4,476 \mathrm{~m})$. This calcite contains $\mathrm{MgO}$ and $\mathrm{FeO}$ in proportions similar to the poikilotopic calcite in the shallowest sample, but it is also enriched in $\mathrm{MnO}$. Grain replacements have compositions only slightly depleted in $\mathrm{FeO}$ and enriched in $\mathrm{MnO}$, relative to the cement.

Two samples were taken from below $15,000 \mathrm{ft}(4,572$ m). Calcite cement in the sample from $15,162 \mathrm{ft}(4,621 \mathrm{~m})$ is essentially pure, whereas cements and grain replacements at $15,173 \mathrm{ft}(4,625 \mathrm{~m})$ are compositionally similar to those occurring in the sample from $11,773 \mathrm{ft}$ $(3,589 \mathrm{~m})$.

In all, at least four unique calcite cement and grain replacement compositions were distinguished, twice the number that could be identified using carbonate staining techniques in conjunction with standard petrographic analysis. The existence of such a variety of calcite compositions within so limited a set of samples strongly supports our views on the sequence of diagenetic events occurring in Tertiary Gulf Coast sandstones. Apparently, calcite precipitation, leaching, and reprecipitation went on almost continuously throughout burial of the sandstones, resulting in multiple, distinctive calcite compositions at various depths (Loucks and others, 1980; Richmann and others, 1980).

A further problem concerning carbonate genesis in Tertiary sandstones is determining the source of calcium. Various sources have been proposed, most notably migration of compaction waters from associated pelitic sediments carrying dissolved $\mathrm{Ca}^{+2}$, which is precipitated as calcite in the sandstones (Boles and Franks, 1979), and albitization of detrital plagioclase within the sandstones, which contributes calcium to form the calcite cements (Boles, 1980). The first model requires that the shale-sandstone system be open to chemical exchange, a condition that is not necessarily requisite to the second model.

Microprobe analyses of detrital feldspars were run on six samples from GCO/DOE Nos. 1 and 2 Pleasant Bayou to determine if albitization is a significant process in Frio sandstone diagenesis. With only one exception, all the detrital plagioclase analyzed was albite $\left(\mathrm{An}_{0-10}\right)$. Furthermore, core-to-rim zoning of both leached and intact grains was not observed. Original zoning of plagioclase would be expected because leaching of detrital plagioclase appears to be preferential; that is, some factor appears to have controlled the sites of leaching within individual grains. Internal compositional variations most likely provided such control. However, any such original variations are no longer present.

These observations suggest that the detrital feldspars were not originally albite, but that their initial 
Table 1. $\delta^{18} \mathrm{O}$ values for subsurface waters in the Chocolate Bayou Field, Brazoria County, Texas. From Kharaka and others (1977a, 1980).

\begin{tabular}{|c|c|c|}
\hline $\begin{array}{c}\text { Depth } \\
(\mathrm{m})\end{array}$ & $\begin{array}{c}\text { Temperature } \\
\left({ }^{\circ} \mathrm{C}\right)\end{array}$ & $\delta^{18} \mathrm{O}(\%)$ \\
\hline 2,626 & 96 & 4.6 \\
2,681 & 99 & 4.1 \\
2,696 & 98 & 4.9 \\
2,981 & 103 & 3.5 \\
3,259 & 117 & 4.9 \\
3,440 & 122 & 3.5 \\
3,463 & 118 & 5.7 \\
3,574 & 127 & 5.6 \\
3,892 & 138 & 4.6 \\
4,161 & 150 & 7.5 \\
4,462 & 138 & 5.4 \\
4,740 & 150 & 4.9 \\
& & \\
\hline
\end{tabular}

compositions have been altered. Assuming that detrital plagioclase originally had an intermediate composition and that albitization occurred at some time after deposition, albitization could have supplied significant amounts of calcium for calcite cementation. While we are certain that albitization does occur in Tertiary sandstones, an estimate of the magnitude of the calcium contribution from albitization requires more specific information on original feldspar compositions and analysis of detrital plagioclase from shallower, updip samples before a mass balance calculation can be attempted. Boles (1980) believes that albitization in Frio sandstones occurs in a temperature range of $100^{\circ}$ to $120^{\circ} \mathrm{C}\left(212^{\circ}\right.$ to $\left.250^{\circ} \mathrm{F}\right)$.

\section{Isotopic Composition of Authigenic Phases}

Five authigenic minerals were analyzed isotopically: calcite, dolomite, quartz, kaolinite, and albite. Two samples of skeletal aragonite enclosed in shale were also analyzed. The authigenic minerals were selected because of their volumetric importance in the sandstones. Results of the analyses are consistent with the possible range of temperatures and water isotopic compositions that have affected Frio sandstones in Brazoria County. A brief discussion in Appendix A outlines the relationship between the isotopic composition of a mineral, the isotopic composition of water, and the temperature. The following two sections summarize what is known about the variation of $\delta^{18} \mathrm{O}_{\mathrm{H}_{2} \mathrm{O}}$ and temperature in the subsurface of the Chocolate Bayou/Danbury Dome area.

\section{Temperature and $\delta^{18} \mathrm{O}_{\mathrm{H}_{2} \mathrm{O}}$}

Brazoria County has undergone net subsidence through the Quaternary (Winker, 1979); thus, it is reasonable to assume that subsurface rocks in Brazoria County have not been significantly uplifted and are currently very near their maximum temperature. Bonham (1980) postulated that subsurface temperatures of some Gulf Coast rocks may have been slightly hotter in the past because of progressive burial of the higher temperature gradient found below the top of geopressure. Isotopic data for sandstones in Brazoria
County, however, show no evidence of former higher temperatures, unless subsurface waters were at some time much heavier. Perhaps by the time sediments now characterized by higher gradients reached equilibrium temperature, they were already buried many thousands of feet because of high subsidence rates.

Frio rocks in Brazoria County were deposited in marine or near-marine settings (Bebout and others, 1978). Water buried with Frio sediments therefore had an isotopic composition similar to sea water or slightly lighter if the water was brackish. Interstitial water can become heavier through time by reaction with the enclosing sediment (Craig, 1966; Clayton and others, 1972; Hitchon and Friedman, 1969; Kharaka and others, 1977b; Land, 1980). Kharaka and others (1977a. 1980) reported a number of isotopic analyses for subsurface waters in Brazoria County (table 1). All the waters are heavy relative to standard mean ocean water (SMOW).

\section{Carbonate Minerals}

Whole rock samples were powdered in a tungsten carbide ball mill and reacted with anhydrous phosphoric acid to produce $\mathrm{CO}_{2}$ gas from the carbonates (McCrea, 1950). All samples were routinely $\mathrm{X}$-rayed, and gases from those samples containing significant quantities of dolomite in addition to calcite were separated using the double extraction technique outlined by Epstein and others (1963).

Grain replacements and cements made of the same mineral cannot be separated chemically, and the small size and intricacy of these features preclude mechanical separation. Instead, detailed petrographic study was used to determine the nature of isotopic variability between different forms of authigenic carbonate. All isotope samples were examined in thin section. Many of the thin sections from GCO/DOE Nos. 1 and 2 Pleasant Bayou were sliced from core plugs immediately adjacent ( 1 to $2 \mathrm{~mm}$ away) to the material actually ground in the ball mill. These sections were then point counted to 500 points to determine the relative proportions of different types of authigenic carbonate. Appendix B gives the results of isotopic analyses of carbonate minerals together with information from petrographic study.

Oxygen Isotopic Data - A plot of oxygen isotope values for calcium carbonates with depth reveals a trend toward lighter values at greater depths (fig. 18). The considerable scatter of values found at any particular depth can be explained at least in part by the variability of calcite types seen in thin section. The two aragonite samples plot to the far right and represent mollusk fragments that have remained virtually unaltered since deposition. Samples dominated by grain replacements and early calcite cement, formed before quartz overgrowths, also plot to the right side of the scatter. Samples composed mainly of pore-filling cement plot mostly on the left of the point distribution (fig. 19).

The isotopic composition of authigenic carbonates reveals the history of cementation. Cements formed at shallow depth have been buried to greater depth and to higher temperatures but have not subsequently recrystallized. If continuous modification had occurred during burial, variability among closely associated samples would not exist, and the points in figures 18 and 19 would show little scatter. It seems plausible, then, that samples farthest left on figure 18 represent those samples most nearly in equilibrium with present 


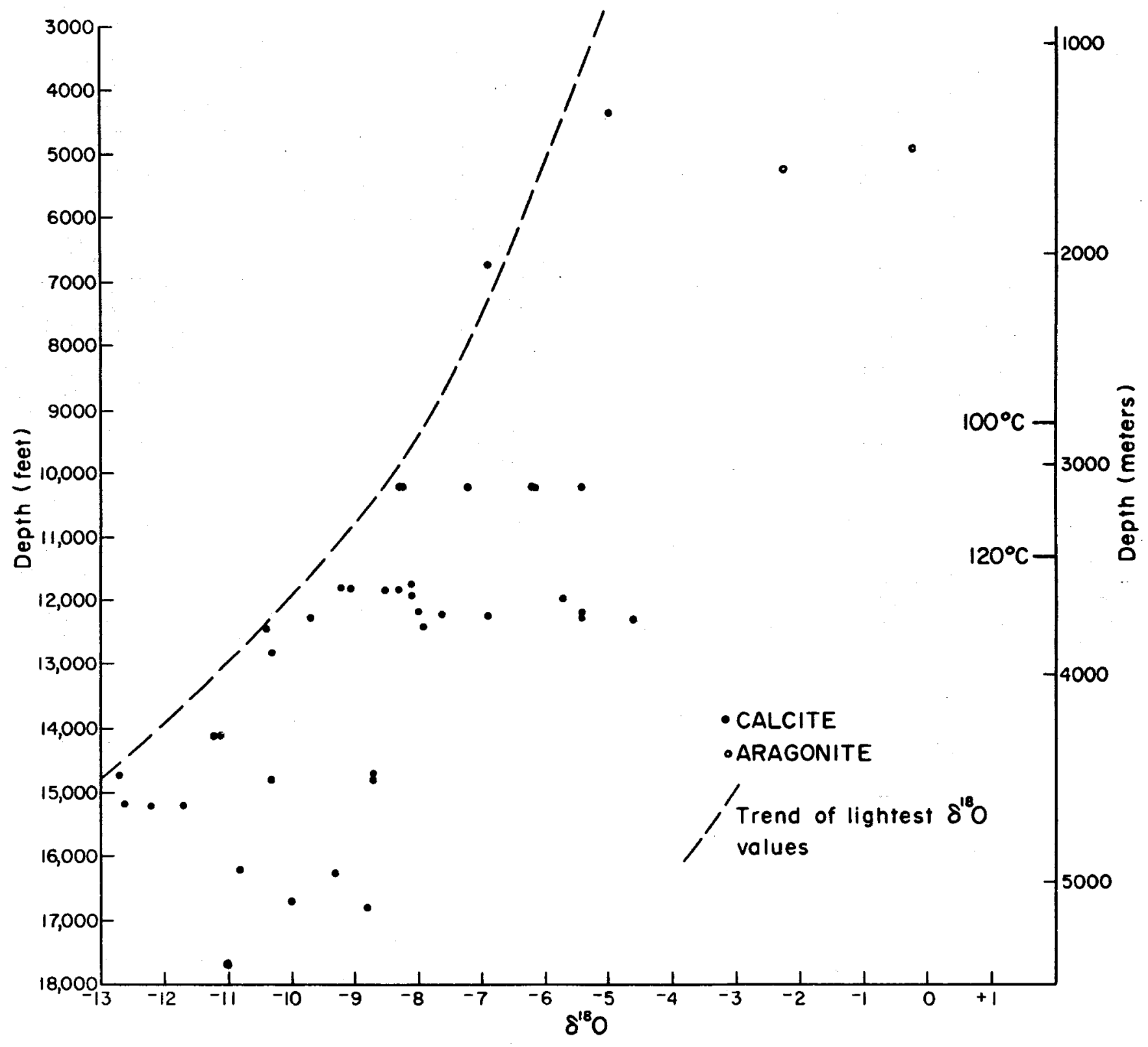

Figure 18. $\delta^{18} \mathrm{O}$ of calcium carbonate versus depth in Brazoria County (reported relative to PDB).

conditions at depth. Those on the right are samples that are farthest from equilibrium, probably having been buried farthest from their point of precipitation and not subsequently recrystallized.

Dolomite samples show a similar trend toward lighter $\delta^{18} \mathrm{O}$ values with depth (fig. 20). The lesser amount of scatter in figure 20 compared to figure 18 probably reflects the smaller number of dolomite samples. Dolomite, in all but one anomalous sample taken immediately adjacent to a salt dome, is 2 to 3 per mil heavier than associated calcite. This is consistent with other observations on differences in fractionations of calcite and dolomite (Land, 1980) and suggests that where these minerals are associated they formed under similar conditions.

In spite of considerable scatter because of preservation of early-formed phases, a clear trend toward lighter $\delta^{18} \mathrm{O}$ values for carbonates with depth remains. Thus, while some carbonates may survive deep burial, the chance of a particular crystal surviving more than $5,000 \mathrm{ft}(1,525 \mathrm{~m})$ of burial is slight. Abundant secondary porosity in the Frio of Brazoria County (Bebout and others, 1978) explains this phenomenon. The burial history of these rocks apparently was characterized by repetitive alternations of carbonate precipitation and dissolution.

Carbon Isotopic Data - Carbon isotope values also exhibit a distinct trend with depth (fig. 21). As with the oxygen isotope data, some scatter in figure 21 can be explained by petrographic fèatures (fig. 22). Overall differences in $\delta^{13} \mathrm{C}$ with depth can be attributed to hydrocarbon maturation. Liquid hydrocarbon generation in the Gulf Coast peaks between $100^{\circ}$ and $120^{\circ} \mathrm{C}\left(212^{\circ}\right.$ and $\left.250^{\circ} \mathrm{F}\right)$ (Bonham, 1980). This zone of peak generation coincides with the marked shift to 

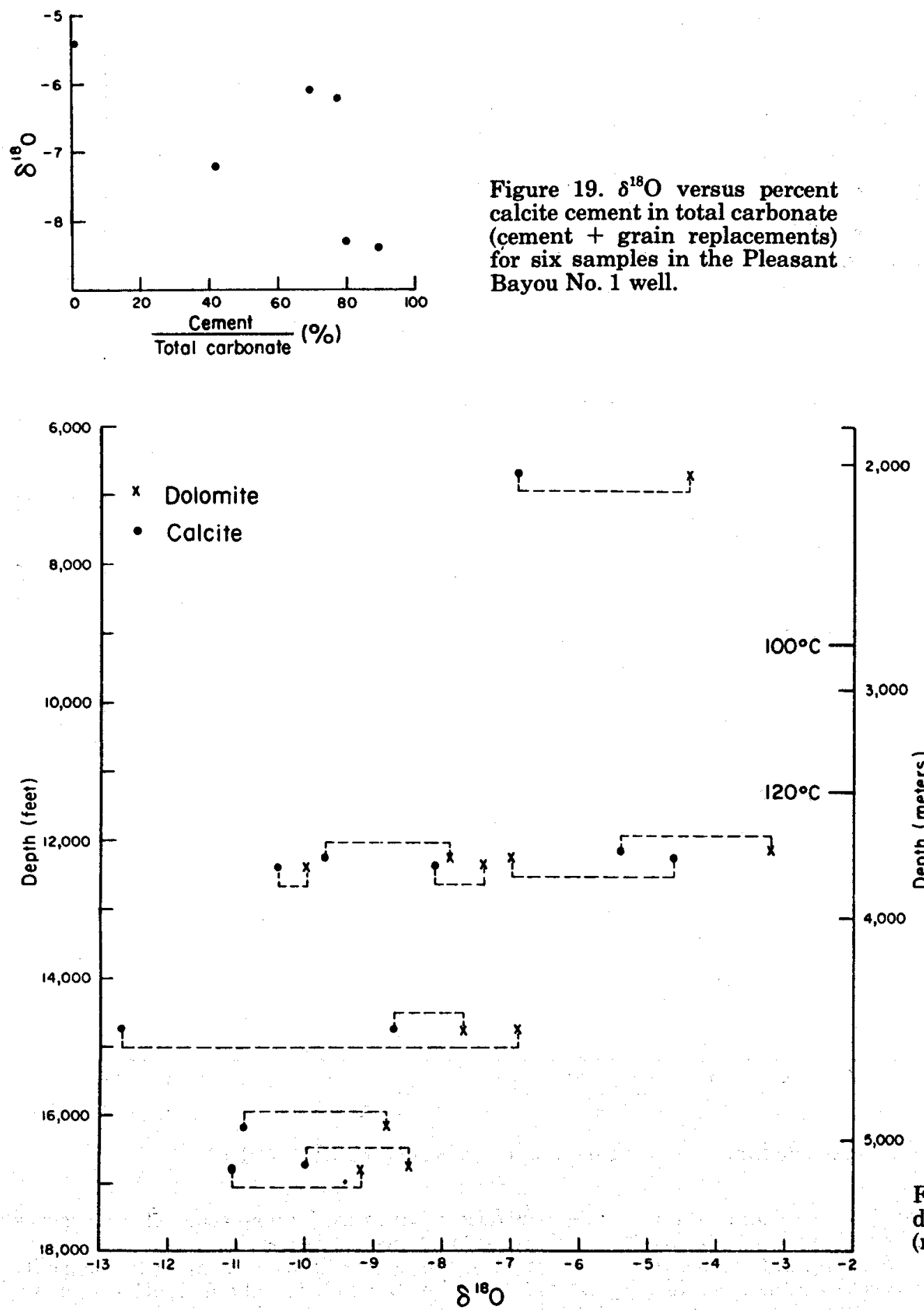

Figure 19. $\delta^{18} O$ versus percent calcite cement in total carbonate (cement + grain replacements) for six samples in the Pleasant Bayou No. 1 well.

Figure 20. $\delta^{18} \mathrm{O}$ versus depth for dolomites and associated calcites (reported PDB).

lighter $\delta^{13} \mathrm{C}$ values between 10,000 and $13,000 \mathrm{ft}(3,050$ and $3,960 \mathrm{~m}$ ). Lighter $\delta^{13} \mathrm{C}$ values for carbonates formed in this zone result from introduction of isotopically light organic carbon from organic reactions into the carbonate system. At depths above this zone, carbon is derived from isotopically heavier sources, perhaps skeletal debris in shales. Below this zone, formation of light methane may preferentially consume light carbon, leaving only heavier carbon for carbonate precipitation. Absence of very light $\delta^{13} \mathrm{C}$ values at greater depths reflects the large amount of secondary porosity in deep Frio sandstones in Brazoria County.

\section{Quartz}

All samples analyzed for quartz content were broken by gentle pounding and further disaggregated ultrasonically. The sediment fraction smaller than 62 $\mu \mathrm{m}$ was decanted to remove fine-grained quartz not accounted for in point counts. Quartz was then isolated 


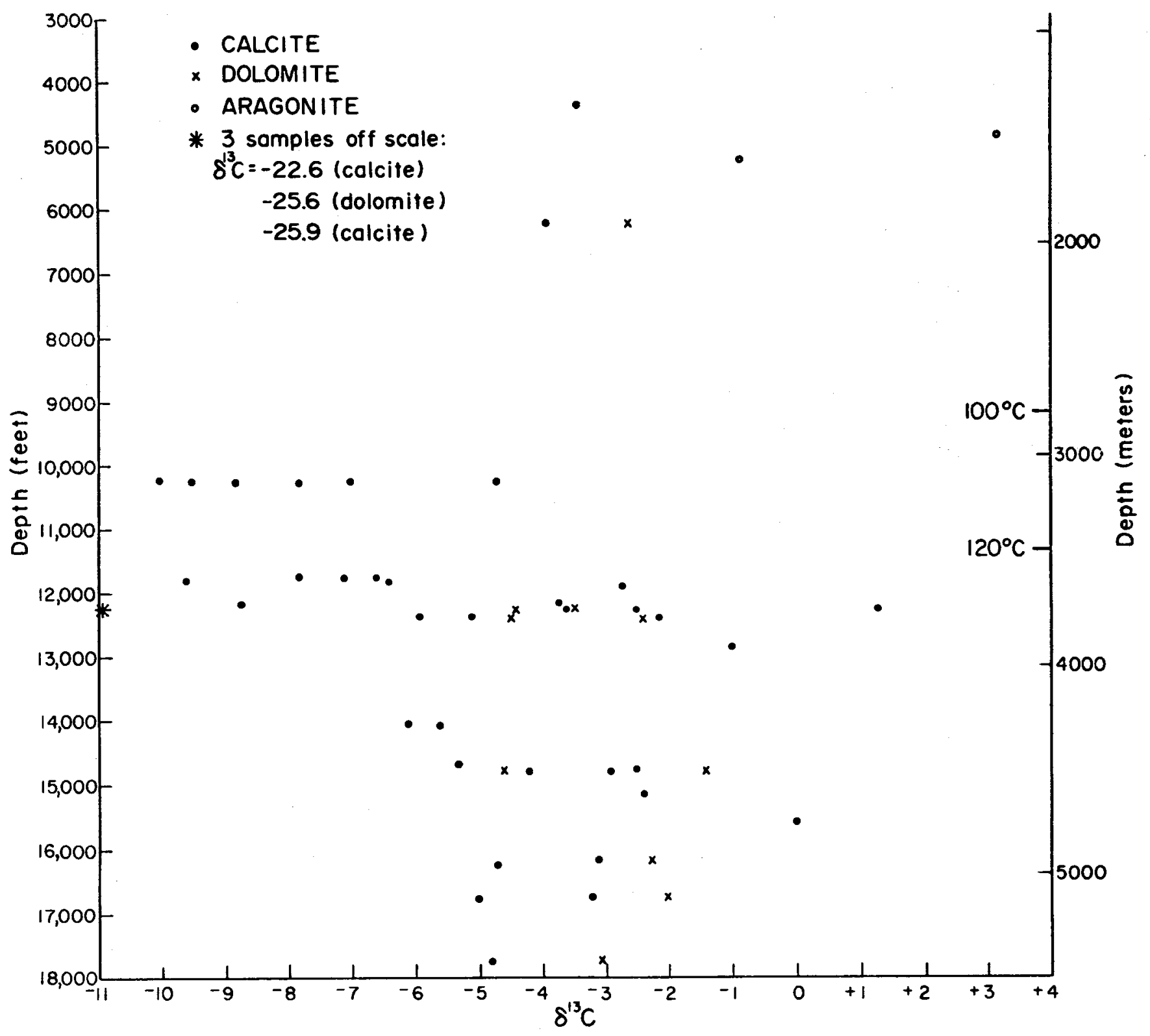

Figure 21. $\delta^{13} \mathrm{C}$ versus depth for carbonate minerals (reported relative to PDB).

using the technique described by Syers and others (1968). All samples were checked for purity by X-ray analysis. Detailed point counts to determine the relative proportions of different quartz types were made on thin sections 1 to $2 \mathrm{~mm}$ away from the samples analyzed.

Oxygen isotope analysis of Frio quartz overgrowths is complicated by two factors: (1) the presence of silicified volcanic rock fragments in addition to detrital igneous quartz and authigenic quartz, and (2) an apparent 3 to 4 per mil variation in $\delta^{18} \mathrm{O}$ of detrital quartz at different depths.

Silicified volcanic rock fragments (VRF's) were hand picked from one sample, 2069. These fragments were treated to isolate quartz. Little weight loss resulted from the quartz isolation process, confirming that these rock fragments are primarily quartz and not zeolites. $\delta^{18} \mathrm{O}$ for the rock fragment quartz was determined to be $29.6 \%$. This value is consistent for silicification of rocks by near-surface water in the Trans-Pecos volcanic source to the west $\left(\delta^{18} \mathrm{O}_{\mathrm{H}_{2} \mathrm{O}} \approx 6.0 \%\right.$ o).

Using this value, corrections were made for each $\delta^{18} \mathrm{O}$ according to the abundance of silicified rock fragments determined from thin section. A plot of these corrected values versus the percent of quartz cement in total quartz, however, does not show a trend that can be extrapolated to give a $\delta^{18} \mathrm{O}$ value for overgrowths. Variation in $\delta^{18} \mathrm{O}$ of detrital quartz and possible differences in $\delta^{18} \mathrm{O}$ of quartz cement at different depths make such a plot meaningless. Plotting only those samples that are closely spaced gives a somewhat better trend and indicates that $\delta^{18} \mathrm{O}$ for quartz overgrowths is around $30 \%$ (fig. 23).

To define $\delta^{18} \mathrm{O}$ for quartz cement more accurately, two quartz samples with relatively large amounts of quartz overgrowths were etched repeatedly in concentrated hydrofluoric acid. Three samples were removed at 


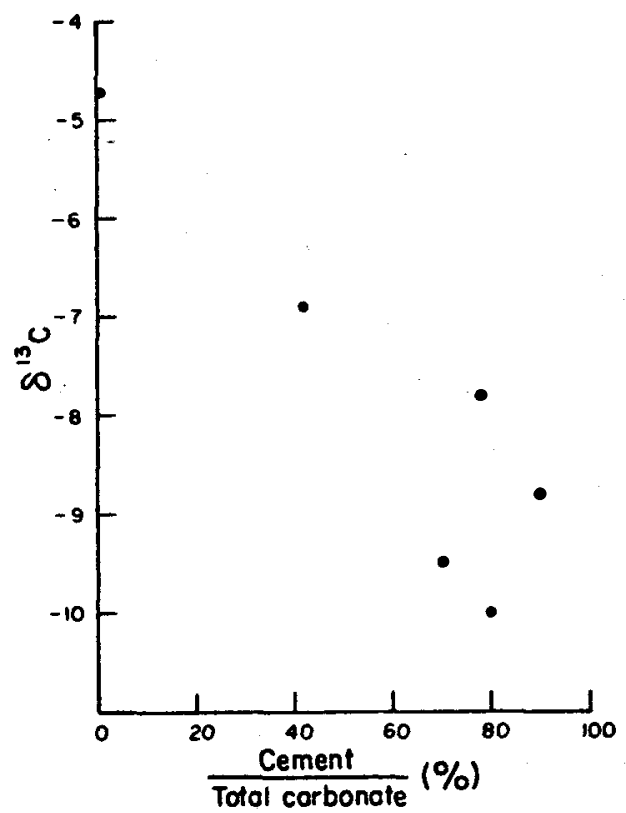

Table 2. Results of etching experiment.

\begin{tabular}{|c|c|c|c|c|c|c|}
\hline \multicolumn{2}{|c|}{$\begin{array}{l}\text { Sample } \\
\text { Number }\end{array}$} & \multirow{2}{*}{$\begin{array}{c}\text { Grains (\%) } \\
82.5 \\
85.5 \\
95.25 \\
99.5\end{array}$} & \multirow{2}{*}{$\begin{array}{l}\text { Quartz Types } \\
\text { Overgrowths (\%) } \\
10.5 \\
9.0 \\
4.75 \\
0.5\end{array}$} & \multirow{2}{*}{$\begin{array}{c}\text { VRF (\%) } \\
7.0 \\
5.5 \\
0 \\
0\end{array}$} & \multirow{2}{*}{$\begin{array}{l}\delta^{18} \mathrm{O} \% \\
15.94 \\
15.15 \\
13.16 \\
12.60\end{array}$} & \multirow{2}{*}{$\begin{array}{c}\begin{array}{c}\delta^{18} \mathrm{O} \% \\
\text { Corrected } \\
\text { for VRF's }\end{array} \\
14.91 \\
14.31 \\
13.16 \\
12.60\end{array}$} \\
\hline 2012 & $\begin{array}{l}\mathbf{A} \\
\mathbf{B} \\
\mathbf{C} \\
\mathbf{D}\end{array}$ & & & & & \\
\hline \multicolumn{7}{|c|}{ (Depth $=14,082 \mathrm{ft}[4,292 \mathrm{~m}])$} \\
\hline 2093 & $\begin{array}{l}\text { A } \\
\text { B } \\
\text { C } \\
\text { D }\end{array}$ & $\begin{array}{r}84.0 \\
85.0 \\
92.0 \\
100.0\end{array}$ & $\begin{array}{c}11.5 \\
10.0 \\
8.0 \\
0\end{array}$ & $\begin{array}{l}4.5 \\
5.0 \\
0 \\
0\end{array}$ & $\begin{array}{l}13.56 \\
13.45 \\
12.05 \\
10.62\end{array}$ & $\begin{array}{l}12.80 \\
12.60 \\
12.05 \\
10.62\end{array}$ \\
\hline
\end{tabular}

Figure 22. $\delta^{13} \mathrm{C}$ versus percent calcite cement in total carbonate (cement + grain replacement) for samples depicted in figure 19. As with the oxygen data, samples dominated by cements are depleted relative to samples with larger proportions of grain replacements.

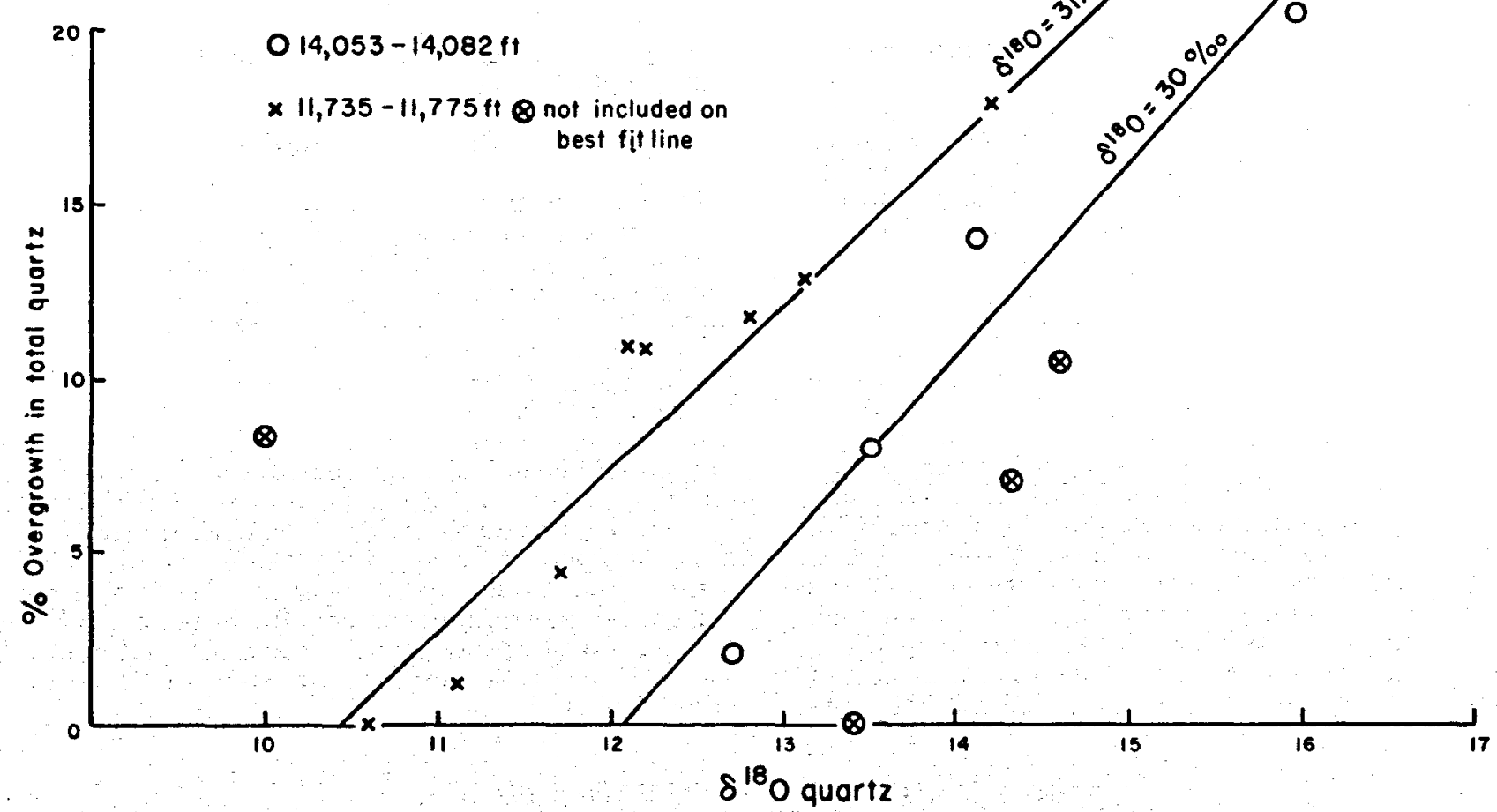

Figure 23. $\delta^{18} \mathrm{O}$ quartz, corrected for rock fragments, versus percent overgrowth in total quartz. Linear regression lines are drawn for two groups of closely spaced samples and indicate a $\delta^{18} \mathrm{O}$ for overgrowths of about $30 \%$. Samples omitted from the left line contain abundant fine-grained quartz suspected to be authigenic, or represent analyses that are suspect.

different times during the etching process in order to determine $\delta^{18} \mathrm{O}$ variation as the quartz overgrowths were progressively removed. A part of each aliquot was used to make a grain mount for point counting. Results are shown in table 2 . When $\delta^{18} O$ values corrected for rock fragments are plotted versus percent cement in total quartz, a much better trend results (fig. 24). Both samples of quartz cement are quite heavy relative to detrital igneous quartz.

\section{Kaolinite}

Authigenic kaolinite was size separated from six samples by settling. Abundant quartz in the same size fraction as kaolinite precluded complete separation. 


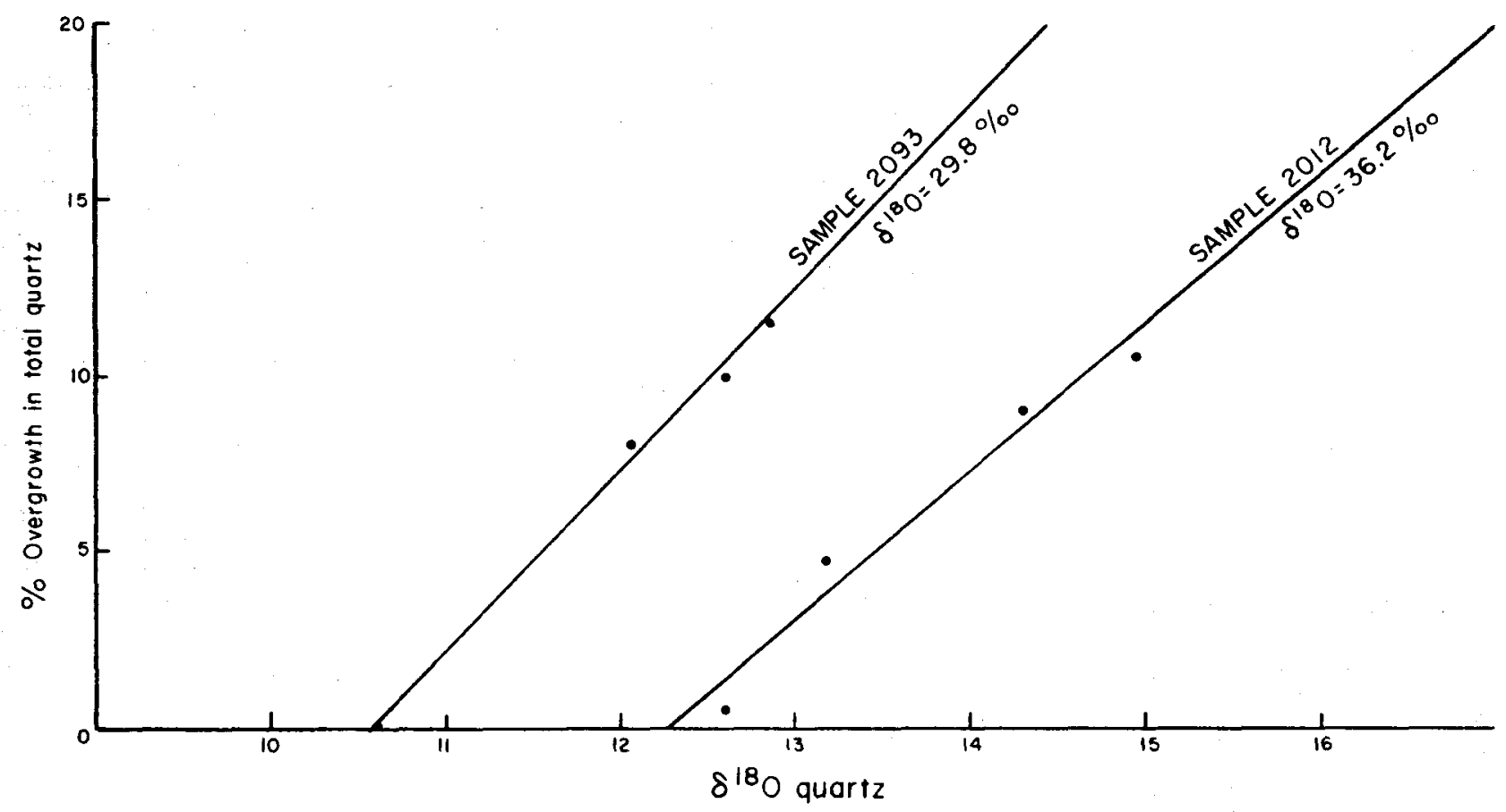

Figure 24. Plot of data from table 2. Values for detrital quartz differ by $2 \%$. The correlation coefficient for 2093 is 0.997 ; for 2012 , it is 0.981 .

Ratios of kaolinite to quartz were determined from $\mathrm{X}$ ray patterns, and the mixtures were analyzed for $\delta^{18} \mathrm{O}$. Kaolinite was then removed from four samples by heating at $600^{\circ} \mathrm{C}\left(1,112^{\circ} \mathrm{F}\right)$ for 4 hours. $\delta^{18} \mathrm{O}$ was determined for the combined quartz of these four samples, and this value was used to calculate $\delta^{18} \mathrm{O}$ for kaolinite in the original mixtures. $\delta^{18} \mathrm{O}$ for kaolinite is around $20 \%$.

\section{Albite}

Albite was picked by hand from one sample (2069). $\delta^{18} \mathrm{O}$ for this sample was determined to be $17.2 \%$.

Given the range of $\delta^{18} \mathrm{O}_{\mathrm{H} 2 \mathrm{O}}$ values observed in Brazoria County (Kharaka and others, 1977a, 1980), temperatures of precipitation for various cements can be established. Isotopic data as related to temperature for carbonates, kaolinite, quartz, albite, and waters are summarized in figure 25. Quartz probably formed at $75^{\circ}$ to $80^{\circ} \mathrm{C}\left(167^{\circ}\right.$ to $\left.176^{\circ} \mathrm{F}\right)$, kaolinite at around $100^{\circ} \mathrm{C}$ $\left(212^{\circ} \mathrm{F}\right)$, and carbonates over temperatures spanning the entire range of depths examined. Albitization took place primarily below $12,000 \mathrm{ft}(3,660 \mathrm{~m})$, at temperatures greater than $120^{\circ} \mathrm{C}\left(250^{\circ} \mathrm{F}\right)$. Relative sequences of events determined in this way corroborate the paragenetic sequences determined for the cements by petrographic study.

\section{Reservoir Quality}

Most of the porosity present in the sampled Frio sandstones is secondary porosity, that is, porosity formed by dissolution of detrital grains and/or cements (fig. 26). Loucks and others (1979) demonstrated that in upper Texas coast Tertiary sandstones large volumes of primary porosity, occluded by carbonate cements early in the diagenetic sequence, are frequently restored in the zone of "soft" geopressure (pressure gradients from 0.465 to $0.7 \mathrm{psi} / \mathrm{ft}$ ). Within this zone, under the appropriate chemical conditions, formation fluids can dissolve pre-existing cements and may also directly leach feldspars and rock fragments. Where the resulting secondary porosity is not occluded subsequently by latestage cements, high-quality geothermal reservoirs may exist at depth. Frio sandstones of Brazoria County have the highest potential for deep reservoir quality of all Texas Gulf Coast Tertiary sandstones (Bebout and others, 1978).

\section{ANALYSIS OF VICKSBURG SANDSTONES, MC ALLEN RANCH FIELD, HIDALGO COUNTY}

\section{Depositional Systems and Structure}

Vicksburg sediments in McAllen Ranch Field were deposited on the downdip side of a large growth fault (Ritch and Kozik, 1971; Loucks, 1978; Berg and others, 1979; Han, 1980). Sands in the lower part of the section were deposited as slightly elongate deltas. A major marine transgression followed deposition of the Vicksburg and deposited a mud-rich shelf to slope section above the deltaic sands. Volumetrically, sand bodies are minor compared with shales, and the shale units effectively enclose the sandstones. Individual sandstone unit thicknesses vary from less than one foot to several hundred feet.

Vicksburg sediments were deposited into the rapidly subsiding ancestral Gulf of Mexico Basin. Rapid loading promoted the development of contemporaneous growth faults, which are the major structures present. Displacement along growth faults is variable, ranging from a few feet to over $4,000 \mathrm{ft}(1,220 \mathrm{~m})$ of offset. 


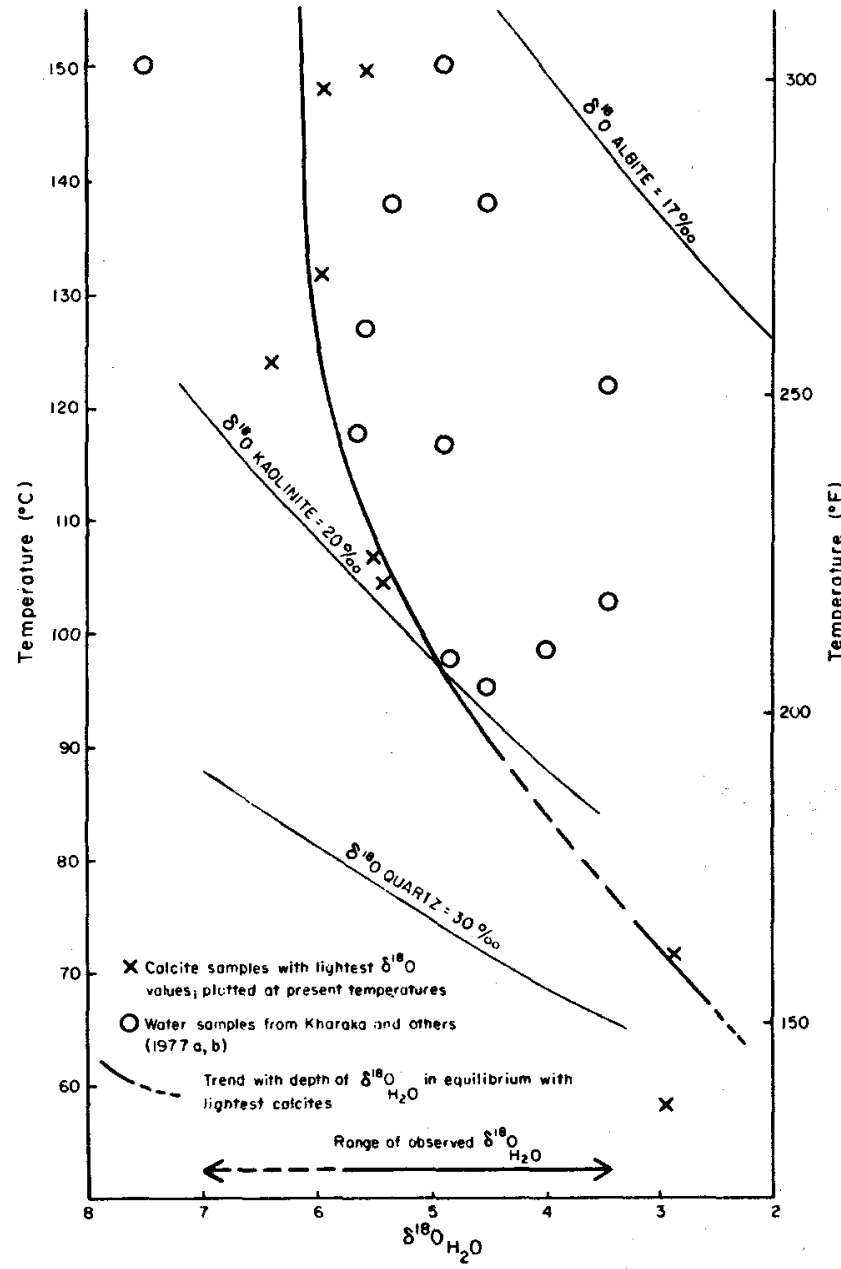

Figure 25. Summary of isotopic data. Equations relating temperature, $\delta^{18} \mathrm{O}_{\mathrm{H}_{2} \mathrm{O}}$ and $\delta^{18} \mathrm{O}_{\min }$ for quartz $\left(10^{3} \ln \alpha=3.38\left(10^{6} \mathrm{~T}^{-2}\right)-3.4\right)$, calcite $\left(10^{3} \ln \alpha=2.78\left(10^{6} \mathrm{~T}^{-2}\right)\right.$ $2.89)$, albite $\left(10^{3} \ln \alpha=2.91\left(10^{6} \mathrm{~T}^{-2}(-3.41)\right.\right.$ are listed by Friedman and O'Neil (1977). The equation for kaolinite $\left(10^{3} \ln \alpha=2.5\left(10^{6} \mathrm{~T}^{-2}\right)-2.87\right)$ is modified from Eslinger (1971).

\section{External Controls on Reservoir Quality}

Depth to the top of the geopressured zone, geothermal gradient, basinal hydrology, and pore fluid chemistry are the most important external variables influencing reservoir quality on a regional scale. In McAllen Ranch Field, the top of the "hard" geopressured zone $(0.7$ $\mathrm{psi} / \mathrm{ft})$ is encountered at approximately $8,500 \mathrm{ft}(2,590$ $m)$. Above the "hard" geopressured zone, the temperature increases with depth at a rate of $1.64^{\circ} \mathrm{F} / 100 \mathrm{ft}$; the geothermal gradient increases to $2.92^{\circ} \mathrm{F} / 100 \mathrm{ft}$ within the "hard" geopressured regime (fig. 27). Similarities in depositional and structural histories between Hidalgo County Vicksburg and Brazoria County Frio sandstones dictate similar basinal hydrologies. Pore fluid data applicable to McAllen Ranch Field are not available. The corresponding section in the discussion of Frio sandstones from Brazoria County contains a summary of currently available information on pore fluids in Tertiary Gulf Coast sandstones. Some studies have addressed the problem of water chemistry variations relative to depth, lithology, and structure, but few

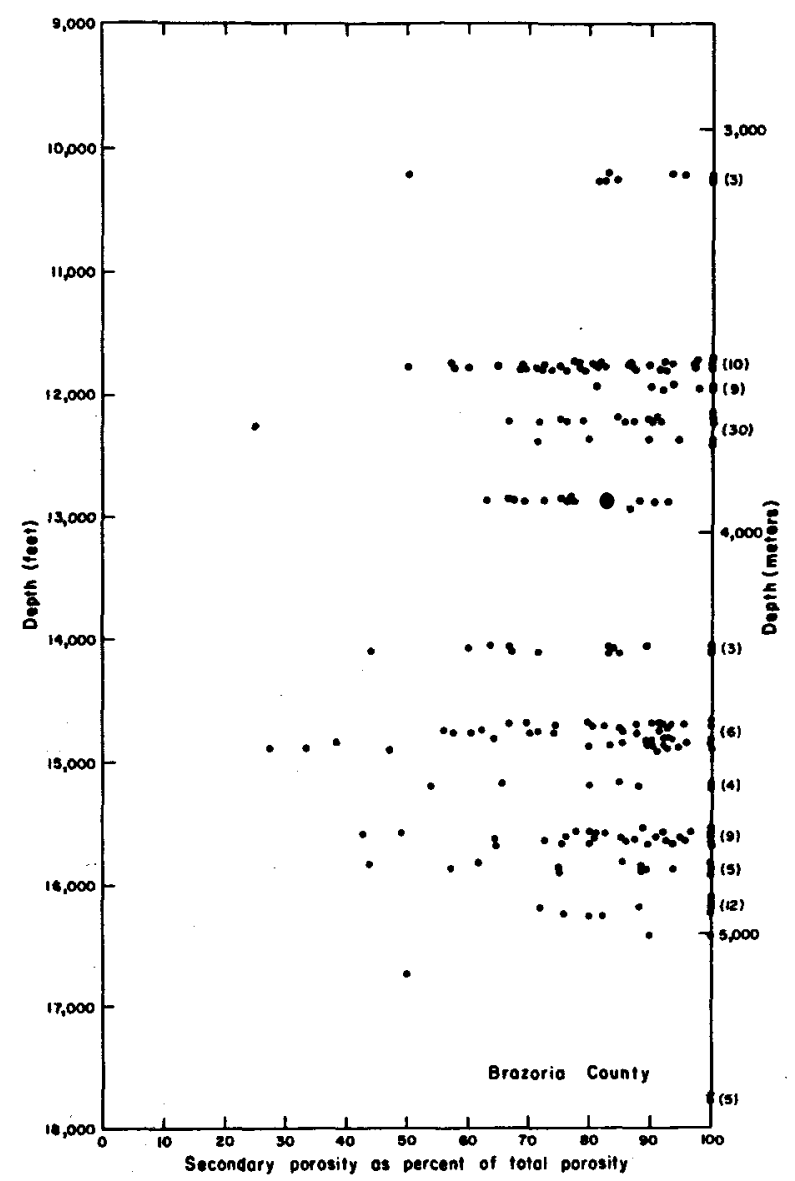

Figure 26. Secondary porosity as percent of total porosity versus depth for Brazoria County samples. Numbers in parentheses represent samples containing only secondary porosity.

patterns have emerged. Kharaka and others (1977a) reported analyses that show generally decreasing subsurface salinities from the Louisiana Gulf Coast southward to Hidalgo County, Texas. They attribute the highest salinities to dissolution of salt domes.

\section{Detrital Mineralogy and Texture}

One hundred one stained Vicksburg thin sections from 10 wells in McAllen Ranch Field, Hidalgo County, Texas, were point counted (200 points per section). The sample selection was purposely biased toward coarsest grain size and lowest matrix content because a greater degree of diagenetic alteration typically characterizes coarser, more porous rocks.

Most Vicksburg sandstones examined are poorly to moderately sorted, fine-grained feldspathic volcanic arenites and lithic arkoses (classification of Folk, 1974), all with less than 30 percent quartz (fig. 28). Feldspars and rock fragments are the most abundant framework grains and occur in subequal amounts. The abundance of these chemically and mechanically unstable grains contributed significantly to the extensive diagenetic 


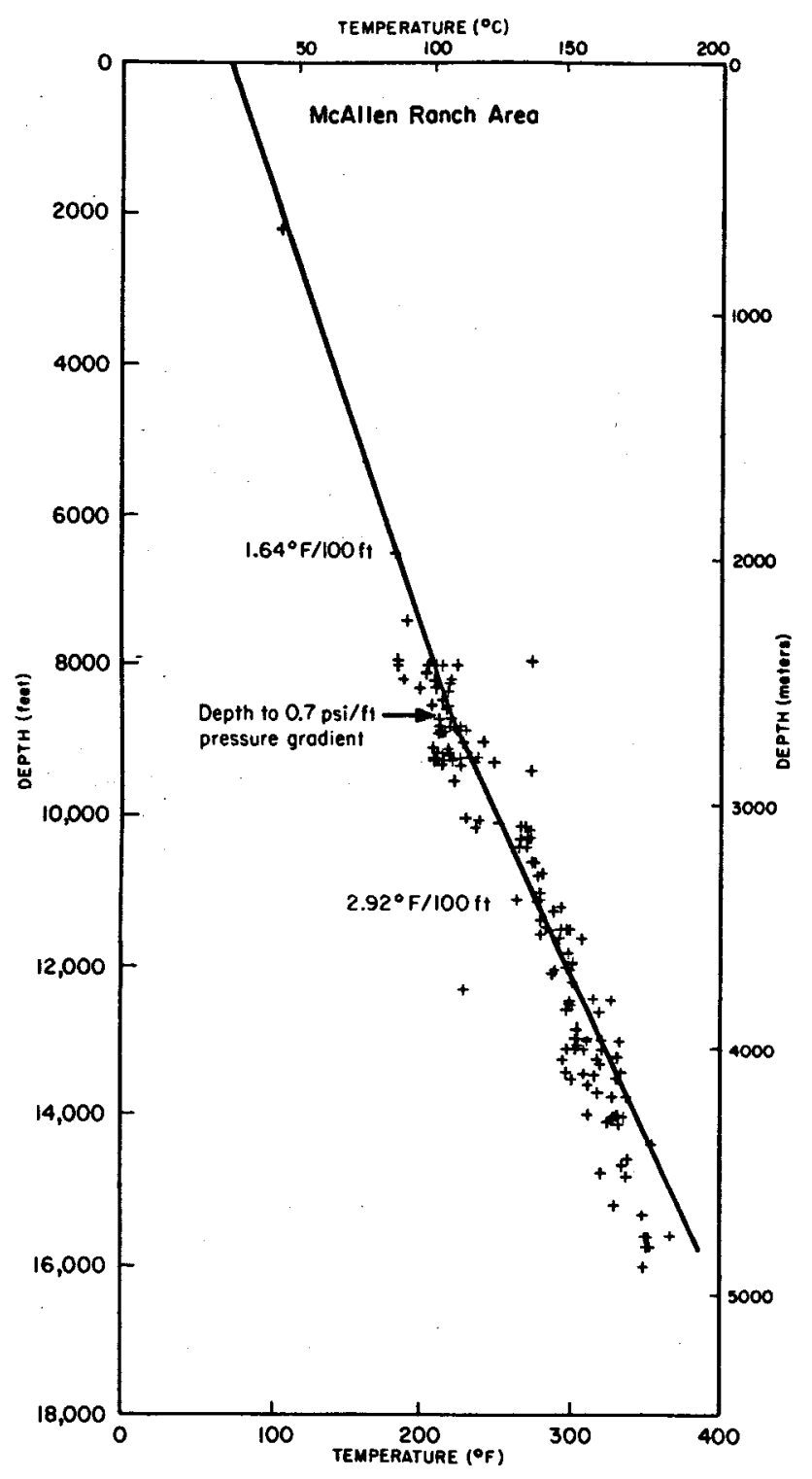

Figure 27. Temperature versus depth, McAllen Ranch area.

modifications that occurred in this area. Detailed descriptions of the various detrital constituents follow.

\section{Quartz}

Detrital quartz content is less than 30 percent and averages approximately 15 percent. Volcanic quartz is the dominant variety, although common quartz is also abundant, and a few metamorphic quartz grains were identified.

\section{Feldspar}

Plagioclase is the most abundant feldspar variety; detrital potassium feldspar is much less common. As in Frio sandstones from Brazoria County, most of the plagioclase is albite. However, grains rarely exhibit typical albite twinning, and we suggest that the present compositions resulted from postdepositional albitization. Vacuolization and sericitization of plagioclase are the most common feldspar alterations; calcite-replaced and leached feldspars are less frequently observed.

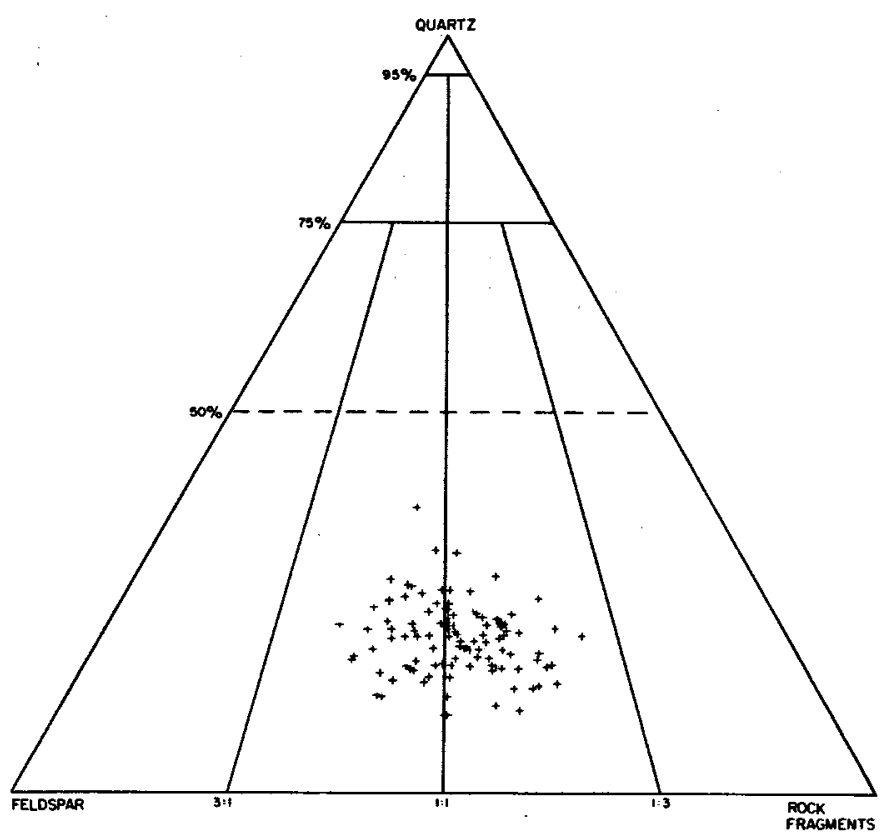

Figure 28. Primary detrital mineralogy, McAllen Ranch area.

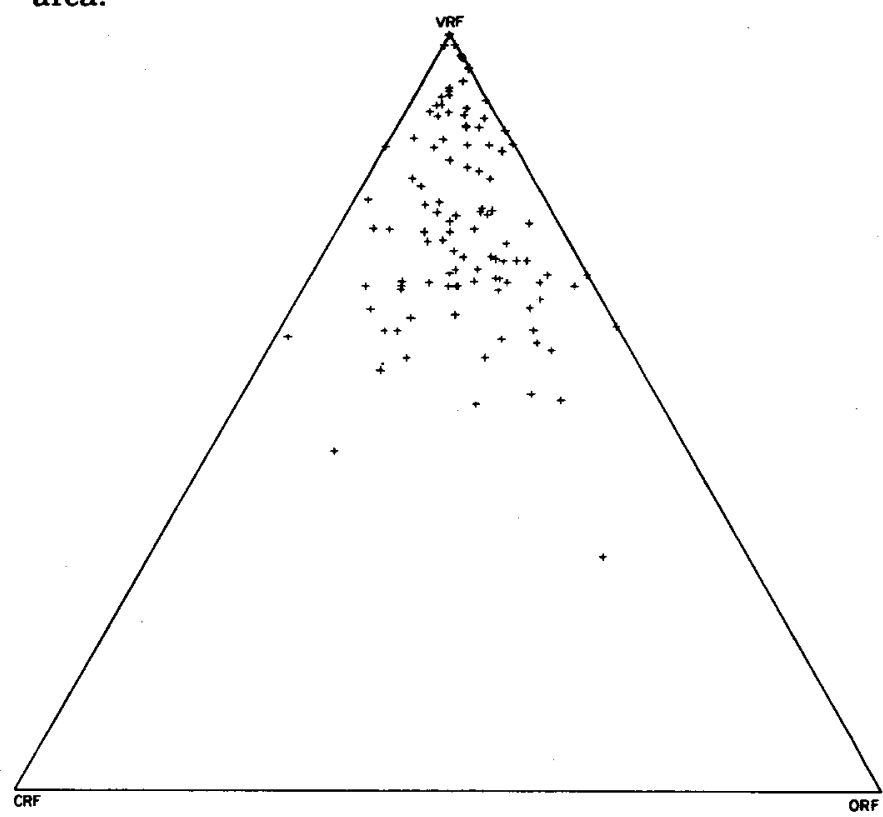

Figure 29. Rock fragment types, McAllen Ranch area. (VRF=volcanic rock fragments; $\mathrm{CRF}=$ carbonate rock fragments; $\mathrm{ORF}=$ other rock fragments (dominantly shale and mudstone clasts). VRF's are the dominant rock fragment type and contribute to the overall chemical and mechanical instability of Vicksburg sandstones.

\section{Rock Fragments}

Volcanic rock fragments (VRF's) are the most abundant type occurring in Vicksburg sandstones (fig. 29). The abundance of VRF's in the Vicksburg reflects the extensive Tertiary volcanism that occurred in West Texas and Mexico. Original volcanic textures are generally well preserved in VRF's, and feldspar phenocrysts are easily recognized in many fragments. A few glassy rock fragments appear relatively fresh; although silicification of very fine grained VRF's is common. Other observed alterations of volcanic rock 


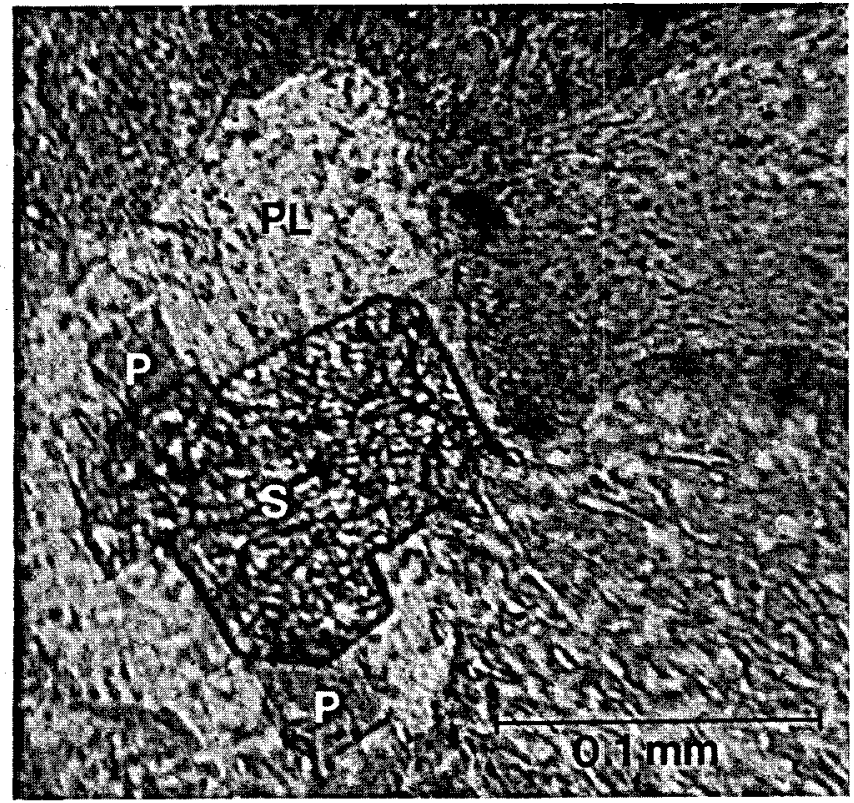

Figure 30. Authigenic sphene (S) partly filling a secondary pore $(P)$ in plagioclase $(P L)$. Plane polarized light.

fragments include replacement by calcite and chlorite, leaching, and alteration to clays. Pseudomatrix in Vicksburg sandstones is composed largely of clayaltered VRF's.

Carbonate rock fragments (CRF's), which are dominantly microspar, are present in variable amounts up to 12 percent. Lindquist (1977) suggested that these clasts were derived from calichified Oligocene soils rather than from a Cretaceous carbonate source. Less abundant rock fragment types include shale and mudstone clasts and metamorphic rock fragments.

\section{Matrix}

Depositional matrix can be important locally, constituting up to $\mathbf{1 8 . 5}$ percent of one sample, but it is a minor constituent overall, owing to the sampling rationale described earlier. However, pseudomatrix, which forms by deformation of mechanically unstable framework grains (Dickinson, 1970), is common because of the abundance of argillaceous rock fragments. Pseudomatrix is a significant inhibitor of porosity and permeability in Vicksburg sandstones.

\section{Diagenetic Modification}

Development of authigenic minerals, chemical alteration of existing minerals, and leaching of chemically unstable cements and grains are the diagenetic reactions occurring in Vicksburg sandstones. In these sandstones, cementation processes dominated processes of dissolution throughout most of the burial history.

\section{Authigenic Minerals}

The authigenic mineralogy of Vicksburg sandstones from McAllen Ranch Field is highly diverse. Multiple major stages of calcite cementation are reflected in the samples, as is an episode of quartz overgrowth development. In addition, several minor cements are preserved. Kaolinite, which forms authigenically in other Tertiary sandstones of the Texas Gulf Coast
(Loucks and others, 1979), is conspicuously absent from all sandstones examined. The absence of kaolinite is one line of evidence suggesting that the chemistry of formation waters in the Vicksburg of McAllen Ranch Field was distinctly different from that of waters in other Tertiary sandstones where good quality deep reservoirs developed (for example, in the Frio sandstone reservoirs in Brazoria County, Texas).

\section{Calcite}

Calcite is the most abundant authigenic constituent in Vicksburg sandstones. The presence of several calcite phases reflects a multistage diagenetic history. Both ferroan and non-ferroan calcite are present as poikilotopic and sparry cements and as grain replacements. However, temporal relationships between coexisting phases are unclear and in some cases cannot be deciphered unequivocally by petrographic means. Ferroan and non-ferroan calcite grain replacements and cements can all be present within a single thin section.

\section{Quartz}

Authigenic quartz is present as overgrowths on detrital quartz grains. Although these overgrowths are ubiquitous in the Vicksburg samples, they are volumetrically minor and therefore do not occlude porosity significantly.

\section{Minor Authigenic Minerals}

A minor $(<2 \%)$ authigenic constituent not previously reported in Vicksburg sandstones is aluminum-bearing sphene. Identified by microprobe analysis, it contains up to 30 percent $\mathrm{Al}^{+3}$ in $\mathrm{Ti}^{+4}$ positions. Sphene occurs as a replacement of VRF's and plagioclase as well as a porefilling mineral. The optical properties are abnormal for sphene. Birefringence rarely exceeds upper second order, refractive indices are lower than for the pure titanium variety, and characteristic rhombic cross sections are rare. Sphene occurs mainly as granular aggregates of anhedral crystals, although a few euhedral crystals were observed in secondary pores (fig. 30).

Albite overgrowths, chlorite rims, and poikilotopic zeolite cement are other minor authigenic components present in Vicksburg sandstones. In general, distribution of these authigenic constituents is sporadic; concentrations of a particular constituent occur in distinct zones and, in some cases, may be restricted to certain wells. Well-developed albite overgrowths are prominent in a number of Vicksburg sandstone samples from the eastern section of McAllen Ranch Field. Overgrowths are seldom in optical continuity with host grains but are occasionally twinned (fig. 31). Chlorite rims and pore-filling cement are present in several samples below $10,000 \mathrm{ft}(3,050 \mathrm{~m})$ and are exceptionally well developed in a number of samples taken below $12,500 \mathrm{ft}(3,810 \mathrm{~m})$ in Forest Oil Nos. 9 and $10 \mathrm{McAllen}$ wells. The delicate structure of the chlorite rims and pore-filling cement attests to their authigenic nature (figs. 32 and 33 ). Poikilotopic zeolite cement and grain replacements occur in samples from four of the wells studied (fig. 34). This zeolite was first identified as laumontite by X-ray analysis, and its identification was subsequently confirmed by SEM equipped with an energy dispersive analyzer. Microprobe analysis indicates that its composition is $\mathrm{Ca}_{0.9} \mathrm{Al}_{1.9} \mathrm{Si}_{4.1} \mathrm{O}_{12} \cdot 4 \mathrm{H}_{2} \mathrm{O}$. Overall, laumontite cementation is volumetrically insignificant, but in the restricted 


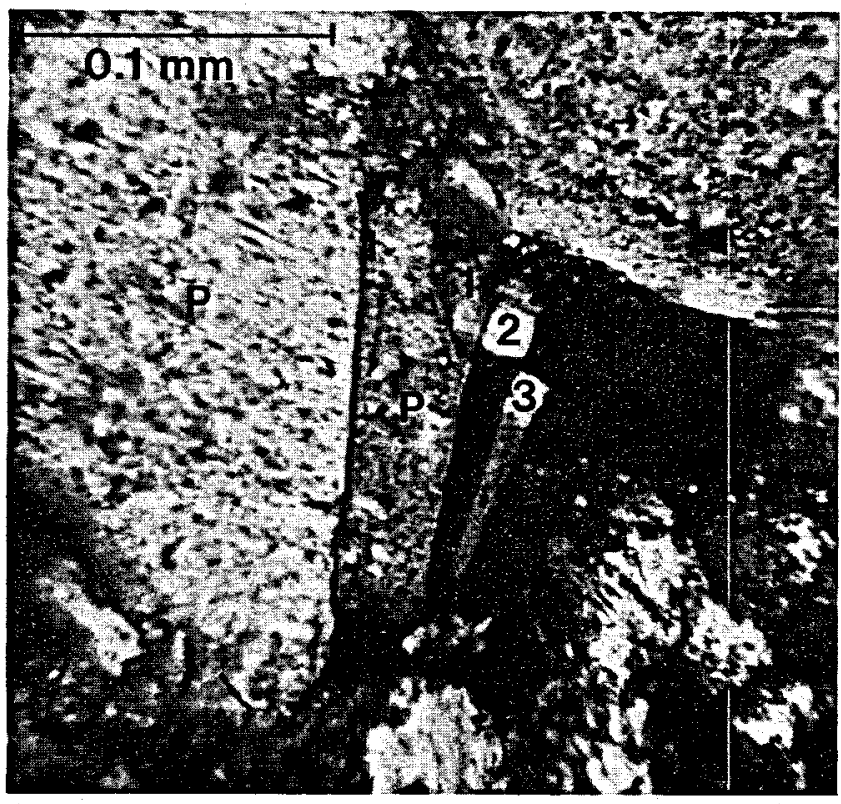

Figure 31. Multiple twinned albite overgrowths $(1,2,3)$ on detrital plagioclase (P). Crossed polars.

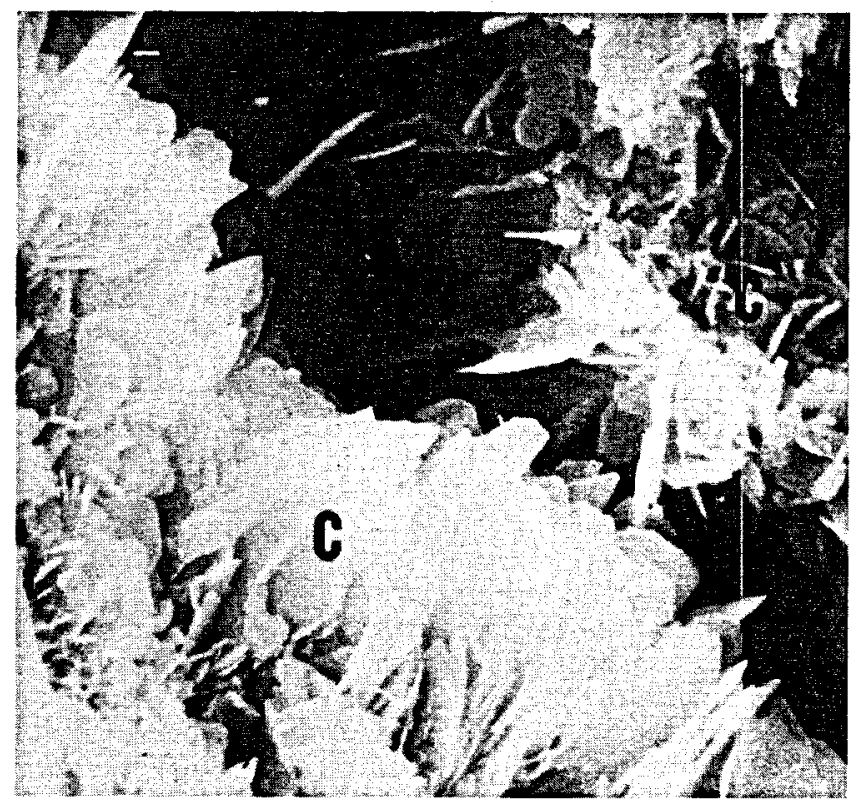

Figure 33. SEM photograph of authigenic chlorite cement (C).

zones where it occurs, it can be a major inhibitor of porosity, constituting up to 17 percent of the sample.

\section{Porosity Types}

Primary porosity may be significant at depths less than $3,000 \mathrm{ft}(900 \mathrm{~m})$. However, with increasing depth, interval transit times decrease sharply, suggesting virtually complete cementation before burial of sediments to $5,000 \mathrm{ft}(1,500 \mathrm{~m})$. Thus, in matrix-free sandstones below $5,000 \mathrm{ft}(1,500 \mathrm{~m})$, secondary porosity is the dominant porosity type (fig. 35). At depths

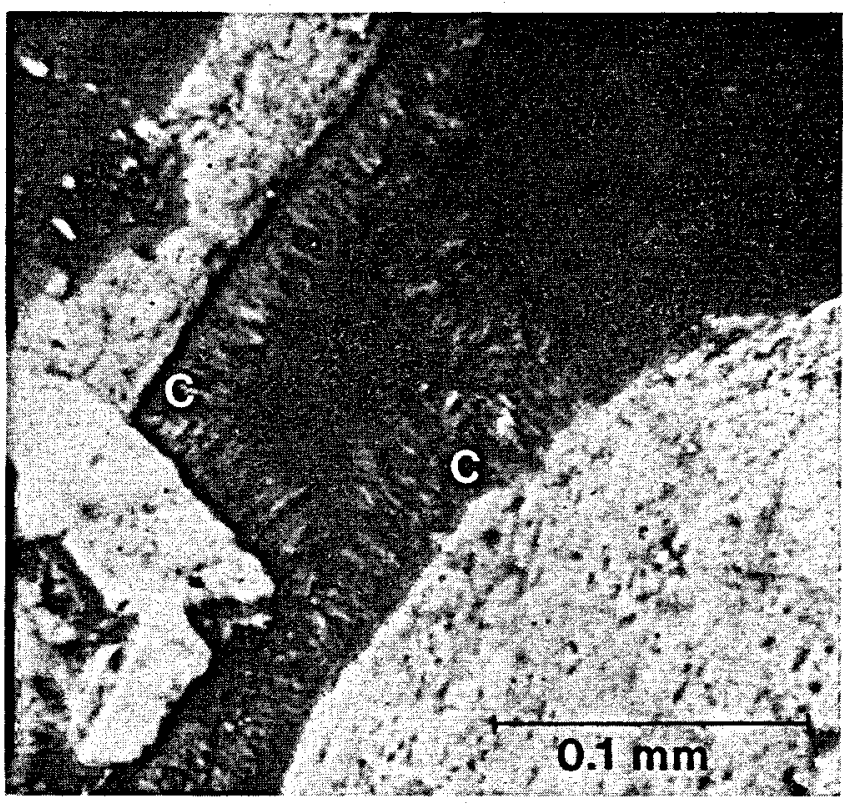

Figure 32. Authigenic chlorite (C) as rims on detrital grains. Crossed polars.

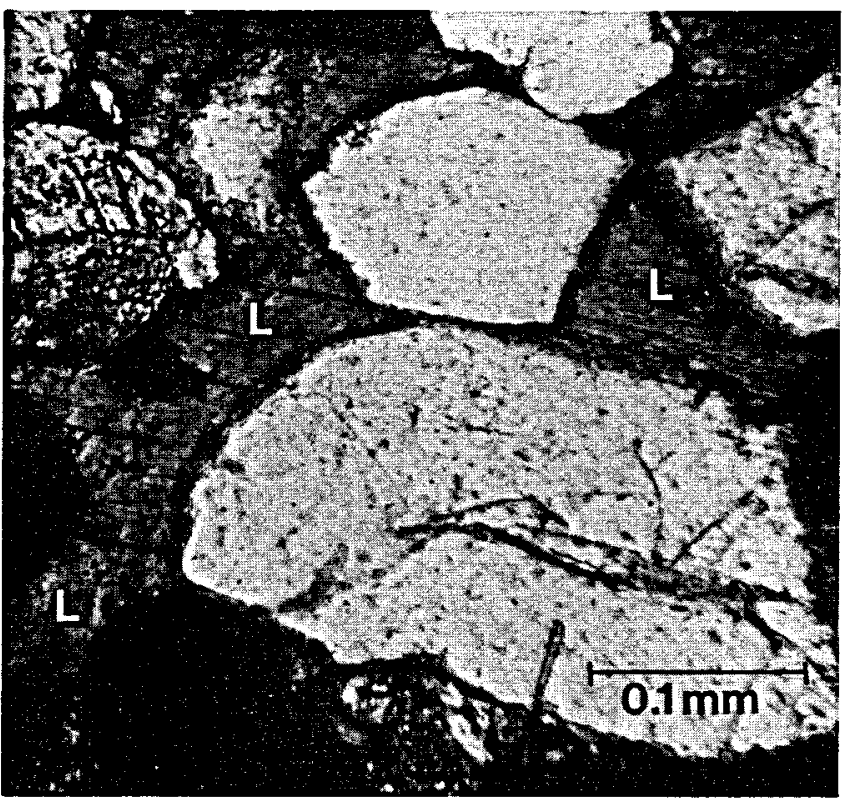

Figure 34. Poikilotopic laumontite cement (L). Crossed polars.

suitable for geopressured geothermal energy production, however, most of this secondary porosity has been occluded by late-stage calcite cements.

\section{Minor Element Chemistry}

Authigenic calcite cement and grain replacements in three Vicksburg samples from McAllen Ranch Field were analyzed for $\mathrm{MgO}, \mathrm{SrO}, \mathrm{CaO}, \mathrm{MnO}$, and $\mathrm{FeO}$ by electron microprobe. The results are tabulated in Appendix C. A review of these data reveals the existence of at least three distinctive calcite generations and 


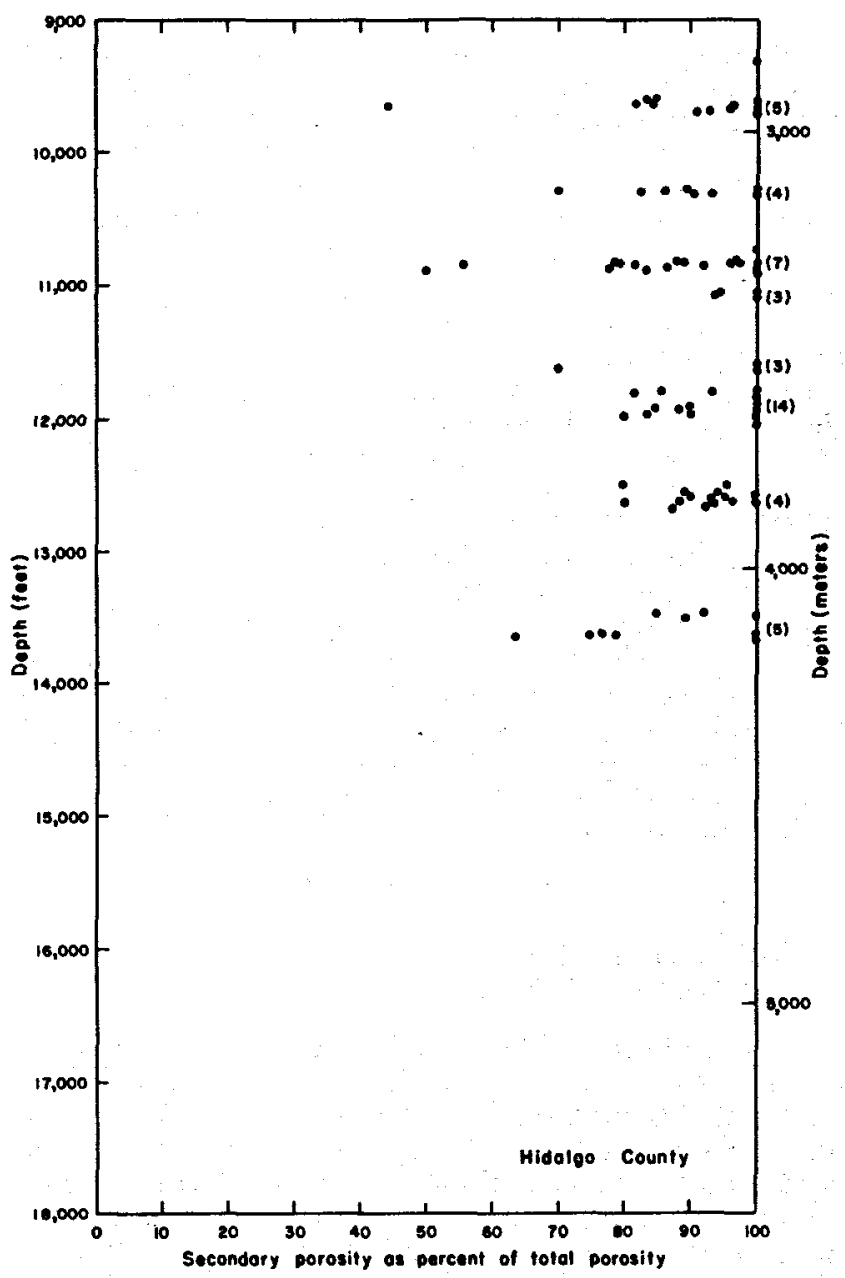

Figure 35. Secondary porosity as percent of total porosity versus depth for Hidalgo County samples. Numbers in parentheses represent samples containing only secondary porosity.

supports our views on the nearly continuous nature of alternate precipitation and leaching. Detrital feldspars were analyzed in five Vicksburg samples. As in Frio samples from Brazoria County, their present compositions are albite. The major source of detrital plagioclase in Vicksburg sandstones in South Texas is the area of Tertiary volcanics in West Texas. Plagioclase in the source area generally has compositions in the range $\mathrm{An}_{20}-\mathrm{An}_{40}$ (C. D. Henry, oral communication, 1979). Thus, it seems certain that extensive postdepositional albitization is responsible for the present plagioclase compositions.

\section{Reservoir Quality}

Multiple generations of carbonate cement are represented in the sandstone samples examined. Calcite cements formed early in the diagenetic sequence and are present in variable amounts in all depth intervals sampled. Authigenic calcite is the major inhibitor of porosity and permeability. Other authigenic replacement minerals and cements are minor and do not contribute significantly to the poor reservoir quality of the McAllen Ranch Field wells. The extent and intensity of calcite cementation do not correlate with abundance of carbonate rock fragments (CRF's), and petrographic observations indicate that CRF's did not serve as nucleation sites for incipient calcite precipitation. The abundance of CRF's (caliche clasts) does, however, indicate that the chemical environment was rich in carbonate at the time of Vicksburg sandstone deposition.

Apparently, the formation waters remained carbonate rich throughout much of the sandstones' burial history. Calcite-cemented zones interfinger with discrete zones containing secondary porosity. We believe that with increasing depth of burial, the sandstone bodies moved through a succession of geochemical environments where some preexisting calcites were leached and new calcites were precipitated. Unfortunately, from a reservoir quality standpoint, calcite precipitation and preservation were far more extensive than calcite leaching, and ferroan calcite cement, formed late in the diagenetic sequence, occluded most deep secondary porosity. Considerable secondary porosity is preserved in zones that were not affected by this late calcite. However, these zones are isolated and do not appear to be volumetrically significant. Even where calcite cements are absent or minimally developed, the chemically unstable detrital mineralogy of the McAllen Ranch Field sandstones contributes significantly to occlusion of porosity and permeability through the formation of pseudomatrix.

\section{PHYSICAL FACTORS CONTROLLING RESERVOIR QUALITY}

McAllen Ranch and Chocolate Bayou/Danbury Dome areas have similar structural and depositional styles as well as similar fluid flow histories. Differences between the two areas are mineralogy, depth to geopressure, and temperature gradient. These differences are responsible for the contrasting reservoir quality in the two areas.

Detrital mineralogy is determined primarily by the mineralogy of the source area. Differences in detrital compositions of sandstones may simply be due to different source areas. Alternatively, different detrital mineral assemblages can be produced from a common source, given sufficiently different climatic conditions and distance along alternate paths of transport from the source.
Climates during Oligocene Vicksburg and Frio deposition were similar to climates along the Texas coast today (Galloway, 1977; Loucks and others, 1979). The lower Texas coast area was arid; the upper Texas coast area was humid. The arid climate in the lower Texas coast produced soil caliches (Lindquist, 1977; Galloway, 1977) and favored preservation of volcanic rock fragments (VRF's) during transport. Hence, the lower Texas Vicksburg contains a large proportion of chemically unstable rock fragments. Soil caliches could not form in the more humid climate of the upper Texas coast, and detrital grains underwent more extensive chemical degradation during transport. Therefore, Frio sandstones in the upper Texas coast are characterized by a more chemically stable mineral assemblage. 
The major source area of Vicksburg sediments in McAllen Ranch Field was the Trans-Pecos region of West Texas and Mexico (Loucks and others, 1979). Extensive volcanism during Vicksburg time contributed volcanic rock fragments, volcanic quartz, feldspars, and glass shards to the sandstones. Glass shards and volcanic ash altered to smectite, which is the major clay component in the system. The Rocky Mountain area may have been the source of some metamorphic rock fragments. Carbonate rock fragments represent locally derived soil caliche.

The Rocky Mountain area may have been a source for the Frio sandstones in the Chocolate Bayou/Danbury Dome area. This area contains a variety of sedimentary, metamorphic, and volcanic rock types. Additional volcanic rock fragments (VRF's) were probably derived from the West Texas area, and abundant volcanic ash from West Texas contributed to the formation of smectite clays.

The greater chemical and mechanical instability of the detrital assemblage in the lower Texas coast as compared with the upper Texas coast contributed to extensive cementation of Vicksburg sediments, resulting in poor reservoir quality, especially at depths necessary for geopressured geothermal reservoirs. As pointed out by Loucks and others (1979), a moderately stable mineral assemblage is necessary to preserve high-quality reservoirs in the deep subsurface. A percentage of unstable components of twenty to thirty actually favors the development of secondary reservoirs, because unstable grains such as feldspars dissolve, creating secondary porosity. However, if the percentage of unstable grains is too high, as in the lower Texas coast, the system becomes choked with cement, and secondary porosity is destroyed.

Depth to the top of geopressure, and hence to the inflection in geothermal gradient, differs in the two study areas. In the Chocolate Bayou/Danbury Dome area the occurrence of "hard" geopressure is deeper $(11,000 \mathrm{ft}$ or $3,350 \mathrm{~m}$, approximately) than in the McAllen Ranch area (about $8,500 \mathrm{ft}$ or $2,590 \mathrm{~m}$ ). In addition, geothermal gradients in the Chocolate Bayou/Danbury Dome area are lower than in the McAllen Ranch area. Together, these two factors (depth to top of geopressure and geothermal gradients) result in overall higher temperatures at any particular depth in the lower Texas coast area. This in turn influences the depth at which the temperature-dependent smectiteillite transformation occurs (Freed, 1980).

\section{EFFECTS OF DIAGENESIS AND BULK CHEMISTRY OF PELITIC SEDIMENTS}

Tertiary sediments along the Texas coast are mainly pelitic (mudstones and shales). Sandstones are common but are only locally abundant. Sandstones were emphasized in past geothermal studies because they are the potential reservoir rocks. To understand the diagenetic system, however, both sandstones and associated pelitic rocks must be studied.

A major question in the study of Gulf Coast diagenesis is whether pelitic rocks represent an open or a closed chemical system relative to associated sandstones. In other words, do chemical reactions within the shales produce ions that subsequently precipitate as authigenic phases in the sandstones? Published findings pertinent to this question are contradictory. Hower and others (1976) found that authigenic products in shales could account for most ions released by clay mineral transitions, requiring no transport of these materials into sandstones. Land and Dutton (1978), however, documented the quantities of silica required for sandstone cementation and concluded that the large amounts necessary can only come from shales. Boles and Franks (1979) suggested that quantities of materials released from shales are small relative to amounts produced by clay reactions and that the material loss from shales is therefore not readily detected.

Argillaceous sediments from two wells in each of Brazoria and Hidalgo Counties were analyzed for this study. We outlined depth-related changes in mineralogy and bulk chemistry of the pelitic sediments and attempted to correlate these changes with diagenetic features in associated sandstones. Other studies of the Gulf Coast area (Burst, 1969; Perry and Hower, 1970; Hower and others, 1976; Yeh and Savin, 1977) have included similar analyses of pelitic sediments, but their conclusions were based solely on the pelitic system. They did not examine the effects of clay diagenesis on the sandstone system. An exception is the study by Boles and Franks (1979) of the effects of clay diagenesis on cementation in Wilcox sandstones in the lower Texas coast. However, the argillaceous system in the Wilcox Group is different from the systems in the Vicksburg and Frio Formations (Perry and Hower, 1970; this study), and results should be extrapolated with caution.

Our discussion will be confined to the major aspects of diagenesis in pelitic sediments as they relate to observed diagenetic features in associated sandstones. A material balance calculation within the pelitic sediments or between the pelitic sediments and the sandstones will not be attempted because our data are not sufficiently quantitative.

\section{Smectite-Illite Transformation}

\section{Chemical Reaction}

Mixed-layer smectite undergoes transformation to mixed-layer illite as temperatures and pressures increase with burial (Weaver, 1958; Burst, 1969; de Segonzac, 1970; Perry and Hower, 1970; Weaver and Beck, 1971; Schmidt, 1973; Hower and others, 1976; Boles and Franks, 1979). The transformation of smectite to illite is potentially important if water and ions released by this reaction migrate into the sandstones where they may affect diagenesis.

Boles and Franks (1979) discussed the role of aluminum in the smectite-illite transition. Using clay mineral formulas from Hower and others (1976), they showed that reactions with aluminum as an immobile component release significantly more cations (most notably, silica release increases more than five times) than do reactions in which aluminum is considered a mobile component.

Burst (1969) calculated the amount of interlayer water expelled during clay diagenesis as 10 to 15 percent of the compacted bulk volume of the argillaceous sediments. This is a large volume of water, given the high ratio of argillaceous sediment to permeable sand beds in the Gulf Coast Basin. This water is thought to be less saline than the normal brines within the sandstone units. 
Table 3. Comparison of sample depth, equilibrium temperature, and illite proportion range for the random to weak order change and the weak to strong order change for each well.

\begin{tabular}{|l|c|c|c|c|c|c|}
\hline Name & \multicolumn{3}{|c|}{ Random to weak order change } & \multicolumn{3}{c|}{ Weak to strong order change } \\
\hline Hidalgo County & $\begin{array}{c}\text { Sample } \\
\text { depth (ft) }\end{array}$ & $\begin{array}{c}\text { Equilibrium } \\
\text { temperature }\left({ }^{\circ} \mathrm{C}\right)\end{array}$ & $\begin{array}{c}\text { Range of } \\
\text { illite } \\
\text { proportion (\%) }\end{array}$ & $\begin{array}{c}\text { Sample } \\
\text { depth (ft) }\end{array}$ & $\begin{array}{c}\text { Equilibrium } \\
\text { temperature }\left({ }^{\circ} \mathrm{C}\right)\end{array}$ & $\begin{array}{c}\text { Range of } \\
\text { illite } \\
\text { proportion (\%) }\end{array}$ \\
\hline \#1 Dixie Mortgage & 5,750 & 79 & $40-59$ & 7,450 & 97 & $70-77$ \\
\hline$\# 3$ A. A. McAllen & 7,850 & 86 & $45-60$ & 9,000 & 106 & $70-75$ \\
\hline Brazoria County & & 116 & $52-57$ & 11,000 & 128 & $63-75$ \\
\hline \#2 Texas State & 9,850 & 119 & $49-63$ & $\begin{array}{c}11,650 \\
*(13,400)\end{array}$ & $\begin{array}{c}123 \\
(142)\end{array}$ & $\begin{array}{c}66-79 \\
(66-79)\end{array}$ \\
\hline $\begin{array}{l}\text { \#1 Pleasant } \\
\text { Bayou }\end{array}$ & 11,400 & & & & & \\
\hline
\end{tabular}

*based only on samples from cuttings (modified from Freed, 1980)

Expulsion of compaction waters transports cations released in the smectite-illite transition into the sandstones where they may precipitate as authigenic phases.

\section{Timing and Depth of Occurrence}

The transformation of randomly interlayered smectite to ordered mixed-layered illite is mainly temperature controlled (Burst, 1969; Perry and Hower, 1970; Hower and others, 1976; this study). Shale cuttings from two wells in each of Brazoria and Hidalgo Counties were X-rayed to determine depth to the smectite-illite transformation. In the lower Texas coast, where the geothermal gradient is higher, the transformation to strongly ordered interlayering occurs at a lesser depth $(7,500$ to $9,000 \mathrm{ft}[2,290$ to 2,740 m]) than in the upper Texas coast $(11,200$ to $11,750 \mathrm{ft}[3,415$ to $3,580 \mathrm{mD}$, where the geothermal gradient is lower. However, other factors also influence the transformation because it occurs at temperatures $25^{\circ}$ to $30^{\circ} \mathrm{C}$ higher in Brazoria County than in Hidalgo County (table 3). The variation in the temperature of transformation in these two areas -may result from differences in pore fluid pressure or differences in primary detrital mineralogy (that is, original ratio of smectite to illite). Another possibility is that the geothermal gradients in the two areas have not been constant throughout geologic history (Bonham, 1980).

In the Gulf Coast area, an empirical relationship exists between the occurrence of the smectite-illite transformation and the top of "hard" geopressure (geopressure as defined by resistivity plots) (Burst, 1969; Schmidt, 1973; this study). Some workers think the clay transformation creates geopressure (Powers, 1967; Foster and Custard, 1980), whereas others think that the relationship is coincidental (Magara, 1975). Our data indicate that the transformation is related to the top of geopressure. This relationship is most likely caused by a thermal seal created by undercompacted shale in the geopressured zone. The temperaturedependent smectite-illite transformation occurs near the zone of increased thermal gradient produced by this thermal seal (Magara, 1975).
Van Olphen (1963) has shown that lithostatic pressure alone cannot be responsible for removal of interlayer water from clays, but rather, it must act in conjunction with temperature to expel water. However, in a geopressured system lithostatic pressure is reduced and fluid pressure increases. Fluid pressure inhibits the expulsion of interlayer water. The quantitative effects of pressure on clay transformation are not well understood and deserve more study.

Another possible control on the smectite-illite transformation is the original ratio of smectite to illite layers in the mixed layered clays and/or other differences in detrital mineralogy. Ordering in the clay does not occur until the mixture is 60 percent or more illite (Freed, 1980). It is probable that the higher the percentage of illite in the pelitic sediment at the time of deposition the lower the temperature needed for the transformation to occur.

\section{Oxide Analyses of Pelitic Rocks}

Pelitic rocks were analyzed for $\mathrm{CaO}, \mathrm{K}_{2} \mathrm{O}, \mathrm{Al}_{2} \mathrm{O}_{3}$, $\mathrm{Na}_{2} \mathrm{O}, \mathrm{MgO}$, and $\mathrm{Fe}_{2} \mathrm{O}_{3}$ to determine whether shales behave as open or closed systems relative to associated sandstones. The samples analyzed were composed of the less than 177-micron size fraction. Samples were not subdivided into narrower size fractions because we were interested only in general trends. Unfortunately, the silica analysis technique we used did not yield reproducible results. Therefore, trends with depth shown in figures 36 through 39 are based on ratios of the various oxides to $\mathrm{Al}_{2} \mathrm{O}_{3}$. Because we assume that aluminum behaves as an immobile constituent in the smectite-illite transition and is therefore confined to the pelitic system, oxide ratios normalized to $\mathrm{Al}_{2} \mathrm{O}_{3}$ should give trends with depth that are actually related to losses and gains in the shales. The contention that aluminum is relatively immobile is supported by the fact that $\mathrm{Al}_{2} \mathrm{O}_{3}$ varies directly with the amount of clay (Perry and Hower, 1970) and that aluminum immobility maximizes the number of cations released (Boles and Franks, 1979). Any significant trends with depth will bear on the question of open or closed sandstone/shale systems. 


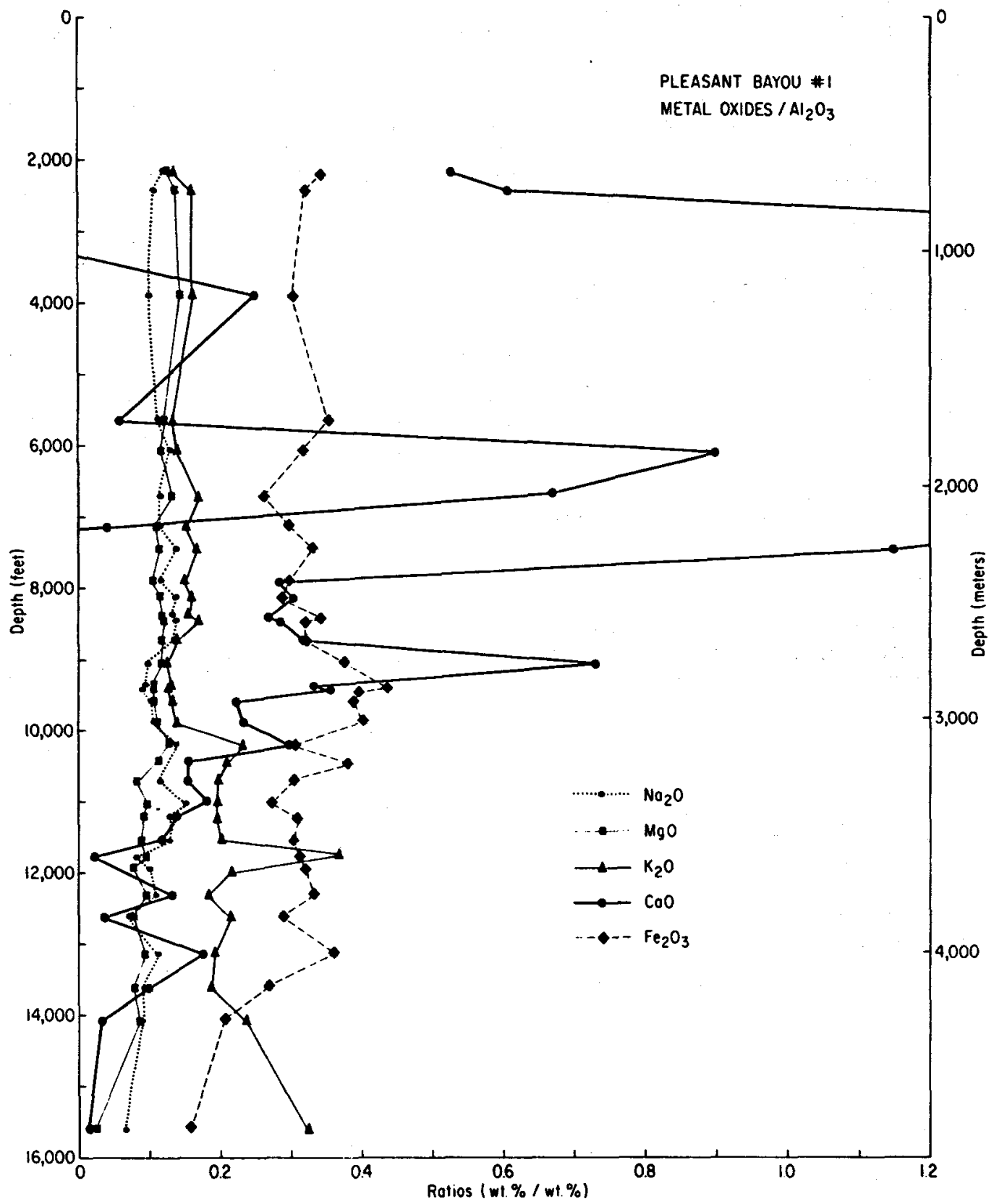

Figure 36. Oxide trends with depth, Pleasant Bayou No. 1, Brazoria County.

\section{$\mathrm{CaO}$}

The ratio of the $\mathrm{CaO}$ to $\mathrm{Al}_{2} \mathrm{O}_{3}$ shows the most variable trend with depth. In the two Brazoria County wells the maximum absolute values and the maximum range of values are found above $10,000 \mathrm{ft}(3,050 \mathrm{~m})$. Below this depth both the $\mathrm{CaO}$ content and its variability decrease. Three explanations for this trend can be offered.

(1) The shale system is open with respect to calcium and loses calcium to the sandstones below $10,000 \mathrm{ft}$ $(3,050 \mathrm{~m})$. Petrographic analyses of sandstones from corresponding depths do not support this possibility because calcite cements decrease with depth.

(2) The shale system is open with respect to calcium, and above $10,000 \mathrm{ft}(3,050 \mathrm{~m})$ receives calcium that is recycled from the leached sandstones lower in the section (leaching is extensive in Frio sandstones from Brazoria County).

(3) The shales are closed systems with respect to calcium, and differences in $\mathrm{CaO}$ reflect primary differences in shale mineralogy (for example, sporadic concentrations of shell debris). This explanation is supported by the sporadic occurrence of the high $\mathrm{CaO} / \mathrm{Al}_{2} \mathrm{O}_{3}$ values above $10,000 \mathrm{ft}(3,050 \mathrm{~m})$.

Overwhelming evidence in support of either explanation 2 or 3 is not found in the data. No trends in $\mathrm{CaO}$ are observed in the Hidalgo County wells. This indicates that either Hidalgo County shales are closed systems or loss of calcium from these shales cannot be detected because of the high total calcite concentration. 


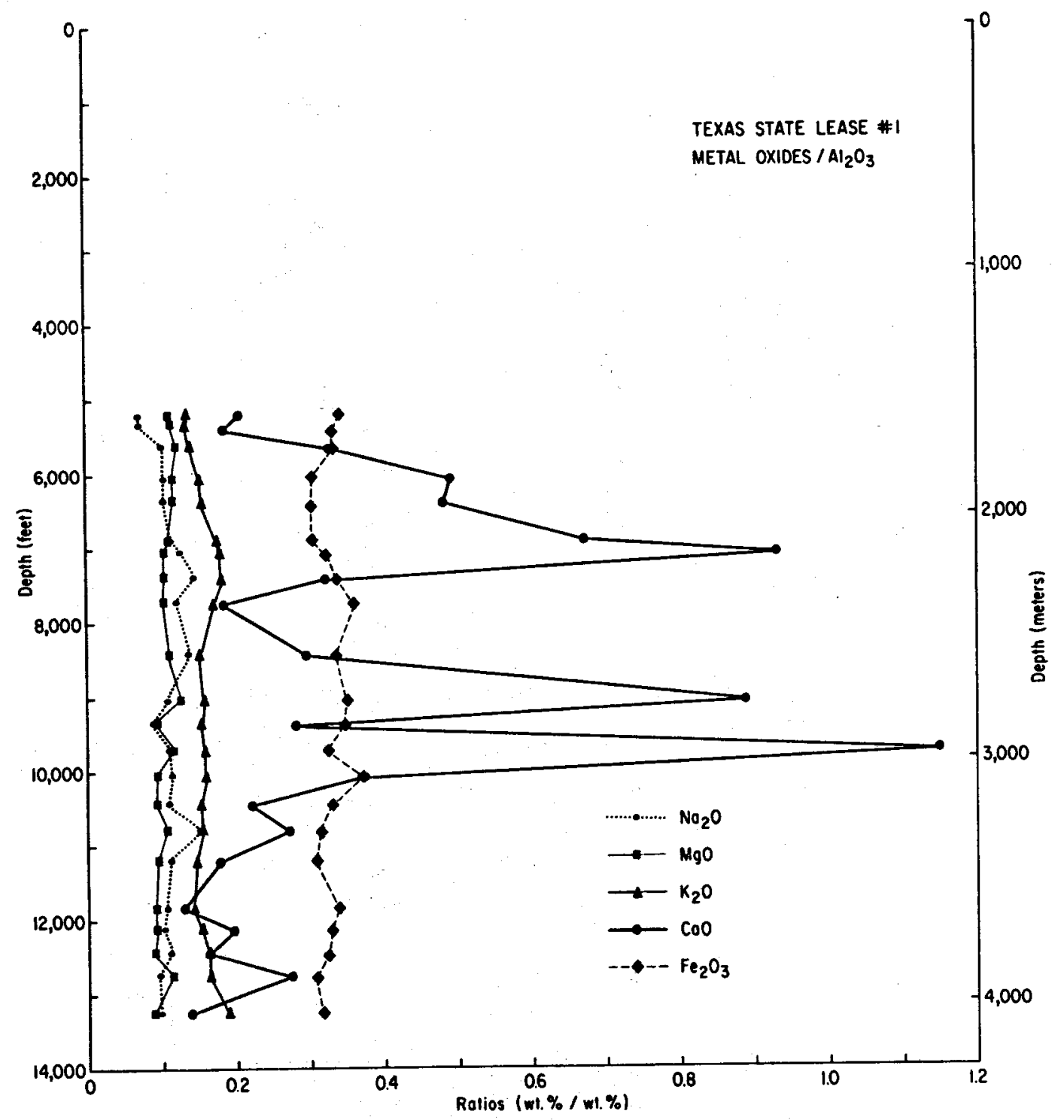

Figure 37. Oxide trends with depth, Texas State Lease No. 1, Brazoria County.

\section{$\mathrm{K}_{2} \mathrm{O}$}

A slight increase in $\mathrm{K}_{2} \mathrm{O}$ was observed in one well in Brazoria County. A plot of $\mathrm{K}_{2} \mathrm{O}$ versus percent expandable layers in the clays for the same well shows that $\mathrm{K}_{2} \mathrm{O}$ varies directly with the amount of illite. Two of the three remaining wells show a similar trend. This suggests that potassium must be added to the system. Potassium may be derived from the coarse fraction of the pelitic rocks that was not analyzed, thus making the shales closed systems with respect to potassium, or from the sandstones if the shales are open.

\section{$\mathrm{Fe}_{2} \mathrm{O}_{3}$}

$\mathrm{Fe}_{2} \mathrm{O}_{3}$ decreases slightly below $13,000 \mathrm{ft}(3,0960 \mathrm{~m})$ in one Brazoria County well. The other wells show no trend with this oxide. Boles and Franks (1979) suggest that iron derived from smectite is responsible for high iron contents in late carbonate cements. However, the most recent authigenic carbonates in the well with loss of $\mathrm{Fe}_{2} \mathrm{O}_{3}$ are iron poor. A few other wells in the Brazoria area have minor amounts of iron-rich carbonates, but the timing of precipitation of these phases is obscure, and these phases are mostly associated with iron-rich grains such as glauconite. Thus differences in $\mathrm{Fe}_{2} \mathrm{O}_{3}$ in the one well that shows a trend are probably due to original differences in mineralogy, and there is no evidence in these data that the shales are open with respect to iron.

\section{$\mathrm{MgO}$ and $\mathrm{Na}_{2} \mathrm{O}$}

No trends with depth for these oxides were observed in any of the four wells studied. Internal recycling of these components seems probable.

\section{Summary}

There is little evidence in the oxide data to support the contention that the shales are open systems with respect to the sandstones. Data for $\mathrm{CaO}$ and $\mathrm{K}_{2} \mathrm{O}$ are the most suggestive of an open pelitic system, but trends in these data can accommodate multiple interpretations. The large quantities of cations required for sandstone 


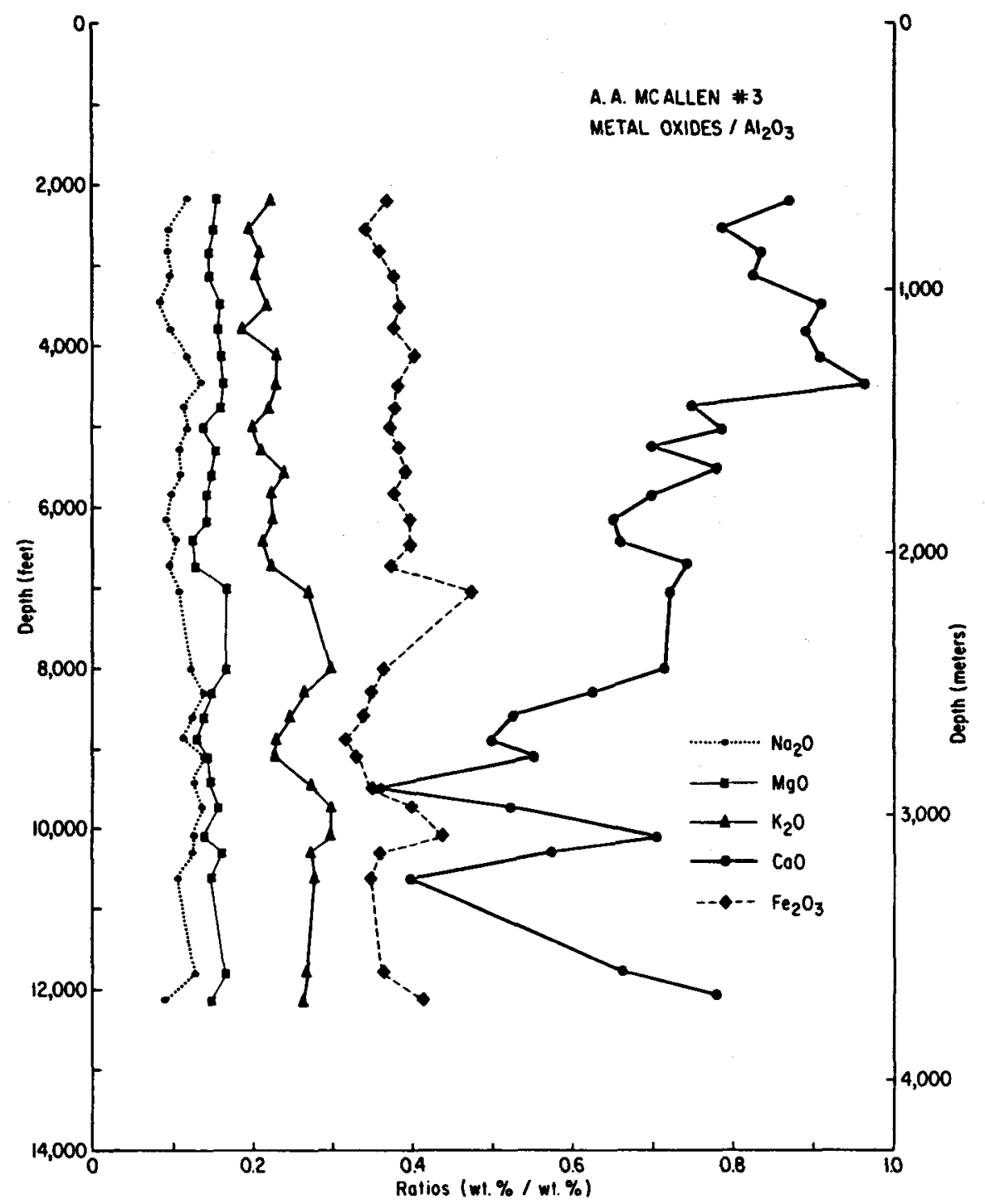

Figure 38. Oxide trends with depth, A. A. McAllen No. 3, Hidalgo County.

diagenesis, however, seemingly must come from shales (Land and Dutton, 1978; Boles and Franks, 1979). The absence of trends in our data does not exclude the possibility suggested by Boles and Franks (1979) that the relative volume of shales to sandstones is so great that material loss too small to be detected in oxide analyses of pelitic rocks may still be significant in sandstone diagenesis. In fact, X-ray data obtained by Freed (1980) on shale samples from the same wells in Brazoria County suggest that mixed-layer clays release silica, carbonate, iron, and magnesium during transformation to the ordered illite-rich structure. In Hidalgo County, however, exchange was more limited, probably restricted to silica. Iron and magnesium released by the clay transformation were used in situ to form authigenic chlorite (Freed, 1980). Until sufficient data are generated on both sandstones and shales to permit mass balance calculations of a highly quantitative nature (including oxide analyses complete with silica data and mineral phase distribution data), this problem cannot be resolved.

\section{COMPARISON OF DIAGENETIC SEQUENCES}

Differences in diagenetic history are largely responsible for the differences in reservoir quality between the two study areas. Combined isotopic and petrographic techniques were used to interpret the sequence of diagenetic events in Frio sandstones in the
Chocolate Bayou/Danbury Dome area. Sequences of events in Vicksburg sandstones of the McAllen Ranch area were interpreted from petrographic data alone because carbonate phases in these rocks are too complex to permit separation for isotopic analysis. 


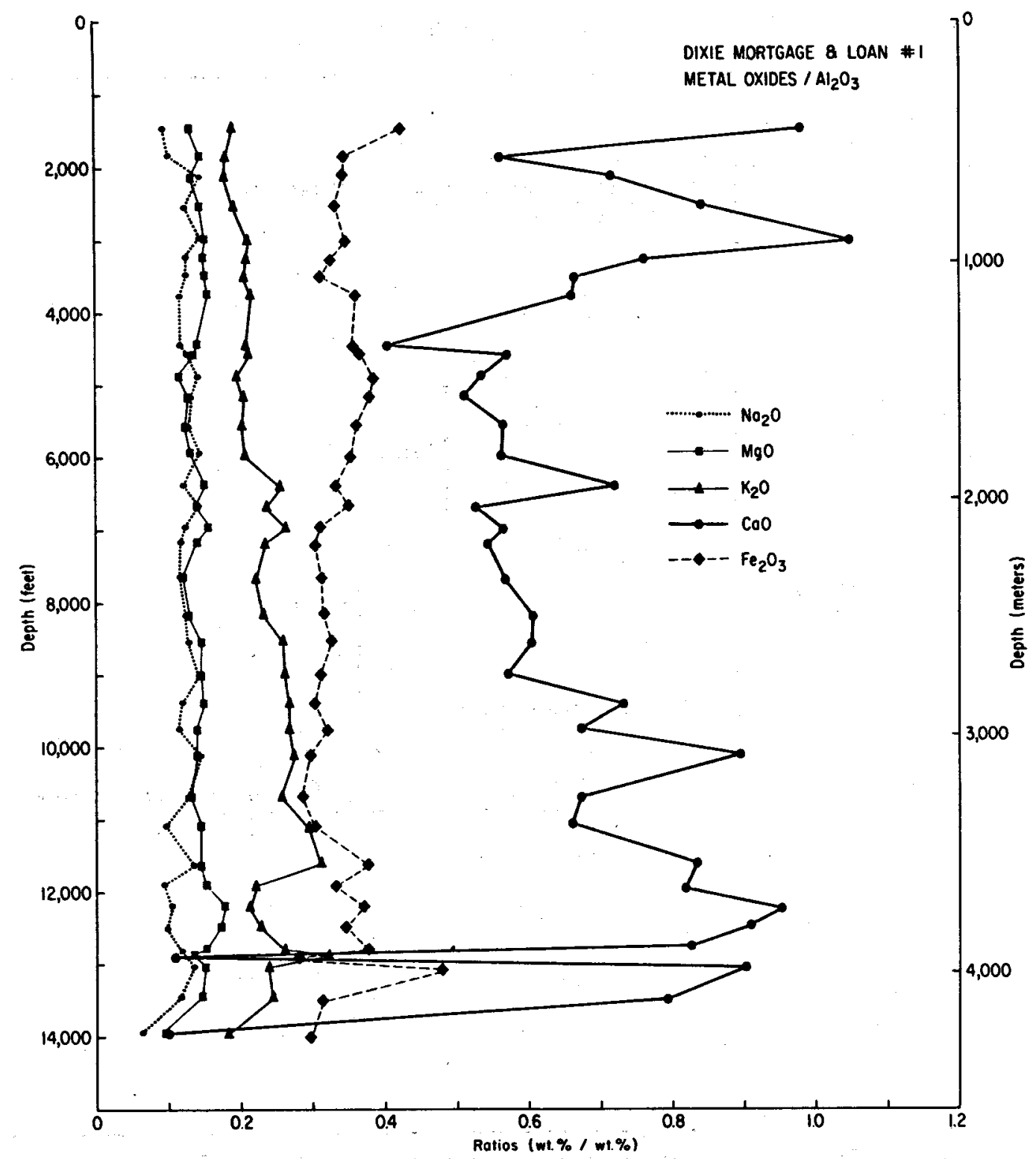

Figure 39. Oxide trends with depth, Dixie Mortgage and Loan No. 1, Hidalgo County.

Information on clay mineral transformations (Freed, 1980) was also integrated into our interpretations of diagenetic history.

\section{Diagenetic History of Chocolate Bayou/Danbury Dome Area}

Figure 40 summarizes the sequence of diagenetic events in the Frio Formation of the Chocolate Bayou/Danbury Dome area. In a regional petrographic study of the Frio, Loucks and others (1979) observed carbonates from the near surface to the deepest occurrence of the Frio and suggest that carbonate precipitation must occur in several stages. In thin sections from the geothermal wells, carbonates both preceded and postdated formation of quartz overgrowths. Secondary porosity largely postdates formation of quartz but occurred both before and after carbonate precipitation. Isotopic data are consistent with these observations. Alternate leaching and precipitation of carbonate minerals must have occurred over the entire range of depths examined and under much shallower conditions as well.

Quartz cements in Brazoria County become important only below $12,000 \mathrm{ft}(3,660 \mathrm{~m})$. Rocks immediately overlying the Frio in Brazoria County are Miocene shales; the sandstones above these shales contain no quartz overgrowths and are mostly unconsolidated. On a regional scale, however, overgrowths appear at much shallower depths, at 5,000 to $6,000 \mathrm{ft}(1,525$ to $1,830 \mathrm{~m})$ (Loucks and others, 1979). In thin section, quartz in Brazoria County appears mainly to predate formation of secondary porosity, suggesting that it formed at shallower depths than it is currently found. The very heavy $\delta^{18} O$ values for quartz overgrowths in Brazoria County are consistent with formation at shallower depths. 


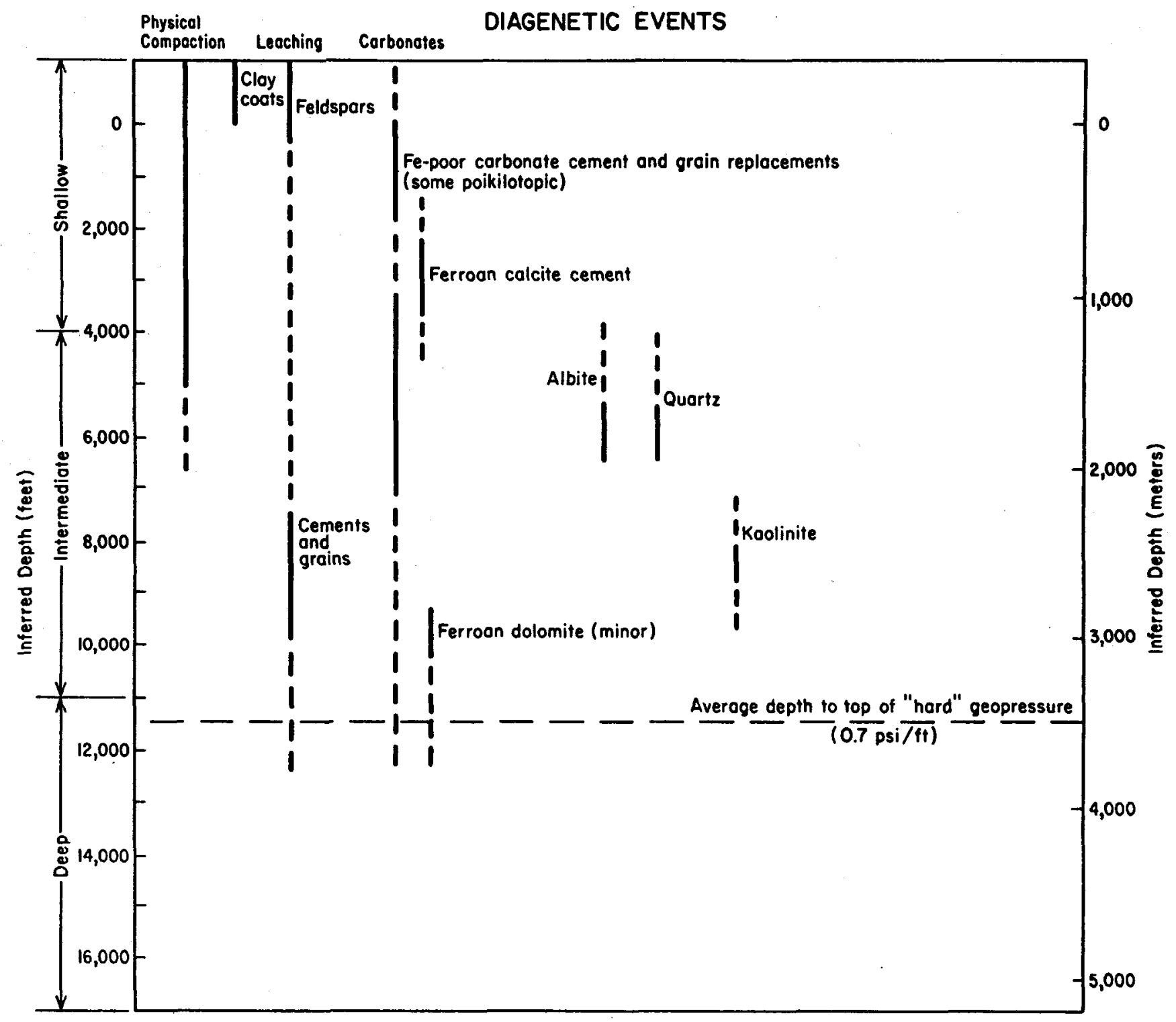

Figure 40. History of diagenetic events, Chocolate Bayou/Danbury Dome area.

Kaolinite occurs mainly filling secondary pores and as a feldspar replacement. It definitely postdates quartz and much of the leaching, but its temporal relationship with much of the late carbonate is unclear. It appears to be the last authigenic phase developed in most of the samples.

In addition to formation of pore-filling minerals, three other processes are important to Frio diagenesis in Brazoria County. One of these is the maturation of organic matter. The other two, albitization and the smectite-illite transition, involve reaction of detrital components with the pore fluid.

Reaction of organic components at some stage during burial may produce acids responsible for leaching and formation of secondary porosity (Schmidt and MacDonald, 1979). Presumably, much of this leaching involves removal of carbonate minerals (Schmidt and MacDonald, 1979). Hydrocarbon maturation processes are known to be one source of dissolved $\mathrm{CO}_{3}{ }^{2}$ in subsurface fluids on the basis of isotopic evidence (Carothers and Kharaka, 1980). Bonham (1980) states that Gulf Coast Tertiary sediments are characterized by peak generation between $100^{\circ}$ and $120^{\circ} \mathrm{C}\left(212^{\circ}\right.$ and $250^{\circ} \mathrm{F}$ ). Authigenic carbonates within this temperature zone in Brazoria County are characterized by an extreme range of $\delta^{13} \mathrm{C}$ values, including a number of extremely light samples (fig. 21). This indicates that some carbon released by organic maturation is used in formation of authigenic minerals. Thus, carbonate diagenesis in the zone of peak hydrocarbon generation is complex, encompassing both precipitation and leaching.

Albitization of feldspars, both alkali-feldspars and plagioclase, occurs with depth in Brazoria County and in other Tertiary rocks along the Gulf Coast (Garbarini and Carpenter, 1978; Boles, 1979). Isotopic data and trends in feldspar composition with depth suggest that the albitization in Brazoria County occurs slightly deeper than the smectite-illite transition.

Textures in calcitized feldspar grains suggest that complete albitization was preceded by most of the grain replacement. This is deduced from the observation that 


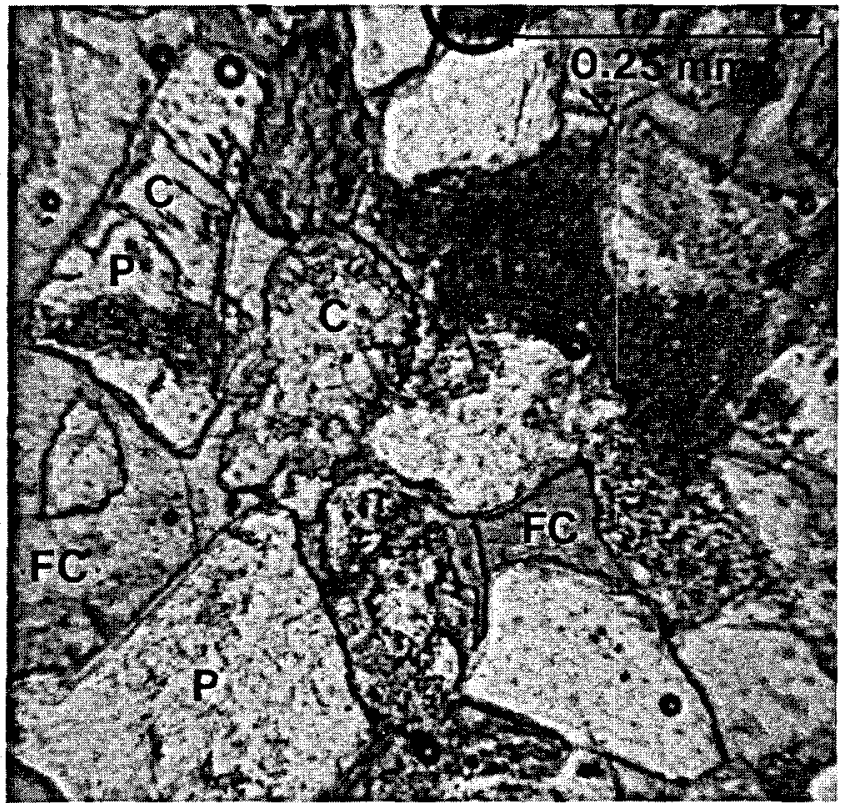

Figure 41. Low porosity sandstone resulting from pervasive calcite cementation, McAllen Ranch area. $\mathrm{P}=$ detrital plagioclase; $\mathbf{C}=$ calcite grain replacement; $\mathrm{FC}=$ ferroan calcite cement. Plane polarized light.

many incompletely calcitized grains consist of calcite cores surrounded by a rim of albite. If complete albitization had occurred before calcitization, there would have been no compositional zoning in the grain to cause the differential replacement. The remaining rims may in some cases be albite overgrowths.

\section{Diagenetic History of McAllen Ranch Field Area}

Calcite is the earliest and the most pervasive authigenic component. Interval transit time data from acoustic logs suggest that cements, which are assumed to be carbonate, are extensively developed by the time the sandstones are buried approximately $5,000 \mathrm{ft}(1,525$ m) deep. In our shallowest thin section sample, framework grains (especially plagioclase) have already undergone extensive replacement by calcite. Poikilotopic ferroan calcite precipitated next in most intergranular pore spaces, resulting in a well-indurated rock with almost no porosity (fig. 41). We have observed no evidence of earlier non-carbonate cementation, which supports our conclusions, based on petrophysical data and on the observations of Frio sandstones from the lower Texas coast (Loucks and others, 1979), that the pervasive cements occurring at shallow depths are carbonate.

Precipitation of poikilotopic ferroan calcite was followed by a major leaching episode that destroyed much of the preexisting calcite cement in certain intervals. Where abundant secondary porosity developed, quartz overgrowths formed with euhedral crystal faces where their growth was unobstructed (fig. 42). Similarly, albite overgrowths grew into secondary pores. Temporal relationships between quartz and albite overgrowth development are difficult to discern because of the chance occurrence of authigenic quartz and albite in contact and because there appear to have

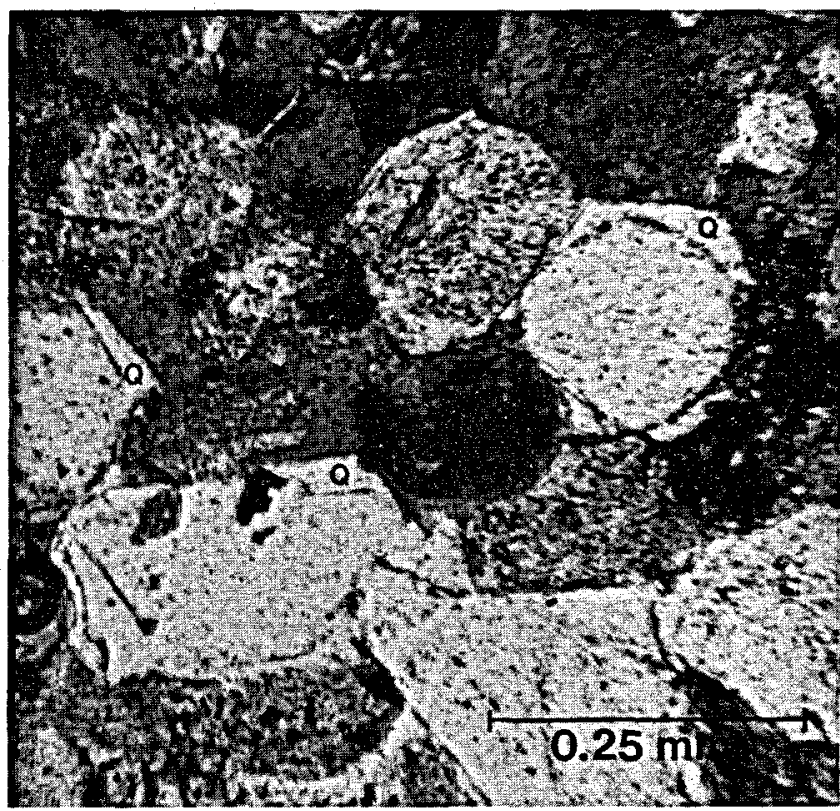

Figure 42. Euhedral quartz overgrowths (Q), McAllen Ranch area. Plane polarized light.

been multiple pulses of albite overgrowth development (fig. 31). Albite overgrowths may have begun to form slightly earlier than quartz overgrowths, but their major periods of development seem to coincide.

In samples where chlorite rims and pore-filling cement are well developed, quartz overgrowths are rare. Authigenic chlorite appears to have formed in secondary pores; therefore, chlorite began to precipitate after the period of carbonate leaching but before quartz cementation. Rims of authigenic chlorite may have inhibited silica-rich fluids from nucleating on detrital quartz grains, which explains, in part, the sparsity of quartz overgrowths in chlorite-rich sandstones. Minor chlorite precipitation persisted beyond the period of quartz cementation, because a small number of grains have chlorite rims developed on quartz overgrowths.

Paragenetic relationships indicate that laumontite precipitation occurred after development of quartz overgrowths (fig. 43). Poikilotopic grains grew into secondary pores and were later partially leached. Additional observations of paragenetic relationships indicate that sphene also formed after development of quartz overgrowths but before the second major episode of iron-poor sparry calcite precipitation.

The second major episode of non-ferroan calcite precipitation occurred following development of the quartz overgrowths and minor cements discussed above. Most of this calcite is present as grain replacements; however, it also occurs with a sparry, pore-filling morphology (fig. 44).

The final stage of calcite precipitation recorded in samples studied occurred before burial of sandstones to $10,600 \mathrm{ft}(3,230 \mathrm{~m})$. This calcite also occurs as sparry pore-fill and, to a lesser extent, as grain replacements; but in contrast to the preceding calcite, it is ferroan. In samples containing abundant ferroan calcite, most secondary porosity is occluded. 


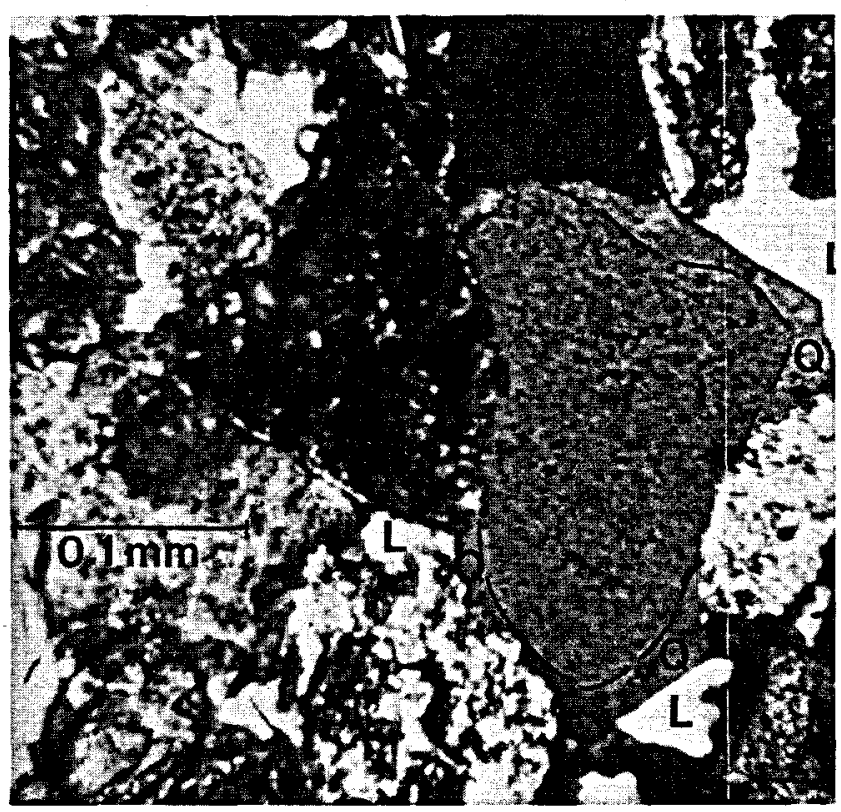

Figure 43. Post-quartz overgrowth (Q), laumontite cement $(\mathrm{L})$. Dashed line indicates the boundary between detrital quartz and its overgrowth. Crossed polars.

The sequence of diagenetic events occurring in Vicksburg sandstones of the McAllen Ranch area is shown in figure 45 . The observed sequence coincides well with the general diagenetic sequence developed by

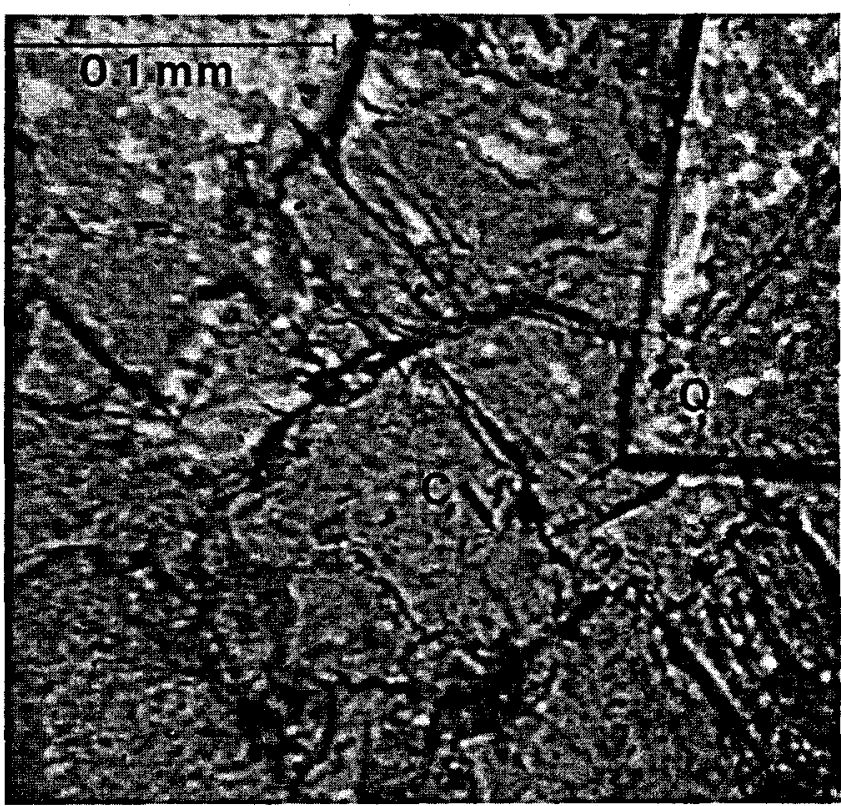

Figure 44. Post-quartz overgrowth (Q), calcite cement (C). Plane polarized light.

Loucks and others (1979) for Tertiary Frio and Vicksburg sandstones of the Texas coast, and depths at which we believe specific diagenetic events were initiated are inferred largely from their study.

\section{CONCLUSIONS}

Table 4 summarizes the characteristics of the Chocolate Bayou/Danbury Dome area and the McAllen Ranch area. These contrasting characteristics promoted differences in the sequence and intensity of diagenesis, which in turn were responsible for differences in reservoir quality in the two areas. The onset of specific diagenetic events is related to depth to the top of geopressure and the temperature gradient. Intensity of reaction is largely a function of the primary detrital composition of the sandstones and shales. In the Vicksburg sandstones of the McAllen Ranch area, multiple generations of carbonate cement are represented in the sandstone samples examined. Calcite cements formed early in the diagenetic sequence and are present in variable amounts in all depth intervals sampled. Analysis of average interval transit times reveals a significant contrast between depths and intensities of cementation in the two areas. A combined plot for three wells in the McAllen Ranch Field area indicates a higher degree of consolidation than do plots

Table 4. Characteristics of Chocolate Bayou/Danbury Dome area and McAllen Ranch area.

\begin{tabular}{|c|c|c|c|c|c|c|c|c|}
\hline Area & $\begin{array}{l}\text { Sediment } \\
\text { source }\end{array}$ & Climate & $\begin{array}{l}\text { Chemical and } \\
\text { mechanical } \\
\text { stability }\end{array}$ & $\begin{array}{l}\text { Carbonate } \\
\text { content } \\
\text { of shales } \\
\text { at depth }\end{array}$ & $\begin{array}{l}\text { Abundance } \\
\text { of carbonate } \\
\text { cement in } \\
\text { sandstones }\end{array}$ & $\begin{array}{l}\text { Depth to top } \\
\text { of "hard". } \\
\text { geopressure } \\
(0.7 \mathrm{psi} / \mathrm{ft})\end{array}$ & $\begin{array}{c}\text { Temperature } \\
\text { gradient } \\
\text { above/below } \\
\text { top of } \\
\text { geopressure }\end{array}$ & $\begin{array}{c}\text { Reservoir } \\
\text { quality } \\
\text { at depth }\end{array}$ \\
\hline $\begin{array}{l}\text { Chocolate } \\
\text { Bayou/Danbury } \\
\text { Dome }\end{array}$ & $\begin{array}{l}\text { Rocky Mountains: } \\
\text { Sedimentary, } \\
\text { metamorphic, } \\
\text { and volcanic }\end{array}$ & Humid & Very stable & Low & Low & $\begin{array}{c}\text { Approximately } \\
11,000 \mathrm{ft} \\
(3,350 \mathrm{~m})\end{array}$ & $\frac{1.35^{\circ} \mathrm{F} / 100 \mathrm{ft}}{2.49^{\circ} \mathrm{F} / 100 \mathrm{ft}}$ & $\begin{array}{c}\text { Poor to } \\
\text { excellent }\end{array}$ \\
\hline & $\begin{array}{c}\text { West Texas: } \\
\text { Volcanic }\end{array}$ & & & & & & & \\
\hline $\begin{array}{c}\text { McAllen } \\
\text { Ranch }\end{array}$ & $\begin{array}{l}\text { West Texas and } \\
\text { Mexico: } \\
\text { Volcanic }\end{array}$ & Arid & Very unstable & $\begin{array}{l}\text { Moderate } \\
\text { to high }\end{array}$ & High & $\begin{array}{c}\text { Approximately } \\
8,000 \mathrm{ft} \\
(2,440 \mathrm{~m}) \\
\end{array}$ & $\frac{1.64^{\circ} \mathrm{F} / 100 \mathrm{ft}}{2.92^{\circ} \mathrm{F} / 100 \mathrm{ft}}$ & $\begin{array}{c}\text { Extremely } \\
\text { poor }\end{array}$ \\
\hline & $\begin{array}{l}\text { Local: } \\
\text { Caliche }\end{array}$ & & & & & & & \\
\hline
\end{tabular}


DIAGENETIC EVENTS

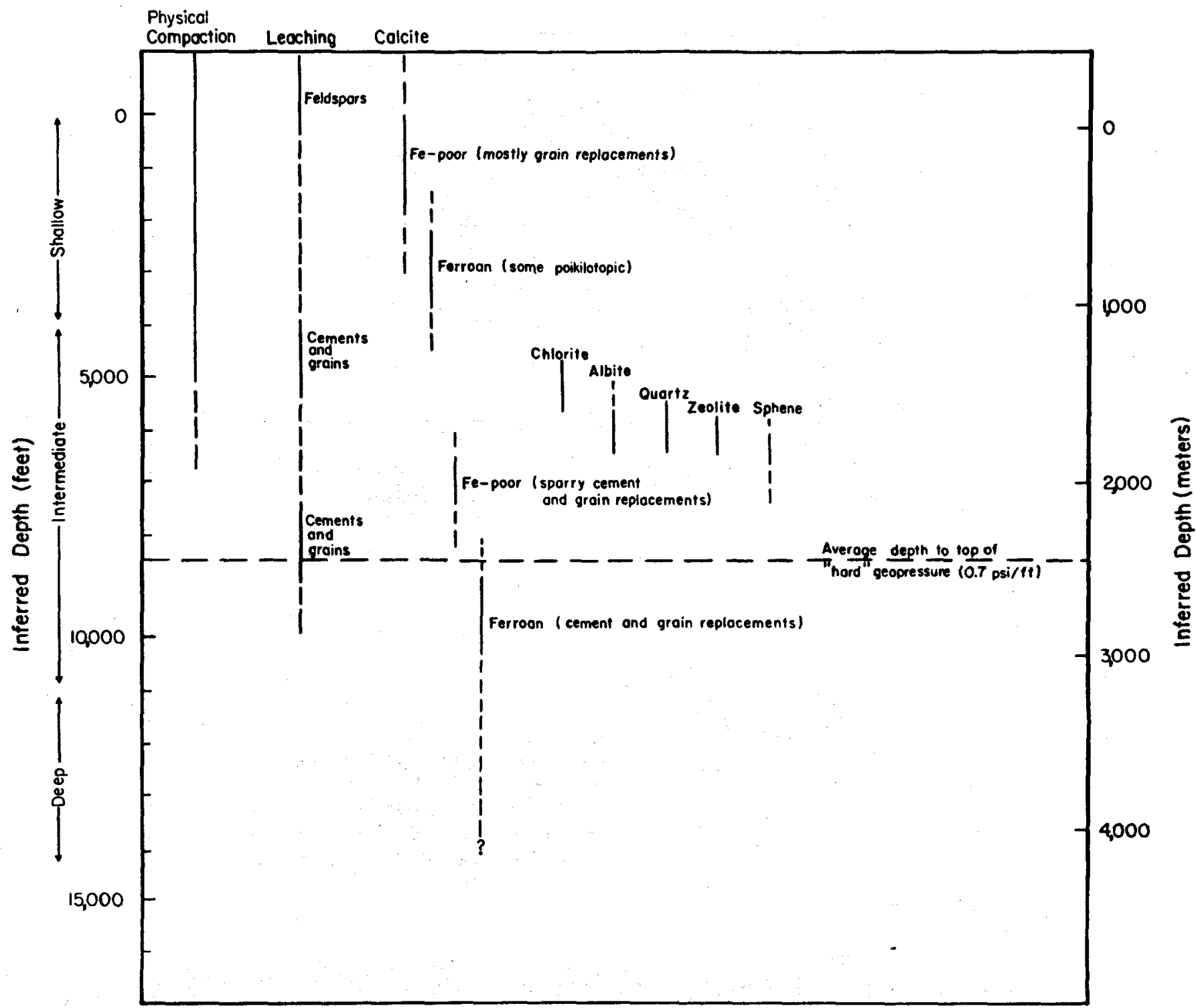

Figure 45. History of diagenetic events, McAllen Ranch area.

for the Danbury Dome area, Chocolate Bayou area, and the two GCO/DOE Pleasant Bayou test wells (fig. 46). A Frio well in Cameron County, coastward from Hidalgo County, was plotted to show the similarity between the lower Vicksburg and Frio Formations in South Texas.

In the McAllen Ranch Field area, Vicksburg sandstones are characterized by a mineralogically immature detrital assemblage. Framework grains are dominantly feldspars and rock fragments that contribute to the overall chemical and mechanical instability of these sandstones. This instability is enhanced by the higher than normal geothermal gradients, relative to other areas of the Texas coast, characterizing McAllen Ranch Field $\left(1.64^{\circ} \mathrm{F} / 100 \mathrm{ft}\right.$ above and $2.92^{\circ} \mathrm{F} / 100 \mathrm{ft}$ within the hard geopressured zone). Figure 47 graphically depicts the contrasting geothermal gradients in Hidalgo and Brazoria Counties. Therefore, in the McAllen Ranch Field area, diagenetic events tend to happen earlier in the consolidation sequence; early-formed authigenic constituents are developed more extensively and tend to persist to a greater extent than those occurring in the upper Texas coast (Loucks and others, 1979). Precipitation of early calcite cements began as shallow as $3,000 \mathrm{ft}(914 \mathrm{~m})$. Virtually all primary porosity was occluded by these cements by the time the sandstones were buried to $5,000 \mathrm{ft}(1,524 \mathrm{~m})$. Apparently, in the Hidalgo County Vicksburg sandstones, post-quartz overgrowth leaching created some good reservoirs with abundant secondary porosity, but these reservoirs were subsequently destroyed by the final episode of ferroan calcite cementation, which occurred before burial of sandstones to $10,600 \mathrm{ft}(3,230 \mathrm{~m})$. Similar destruction of secondary porosity by late iron-rich carbonate cement was shown by Loucks and others (1977) to be the major cause of the poor quality of deep Frio and Vicksburg sandstone reservoirs in the lower Texas coast. 


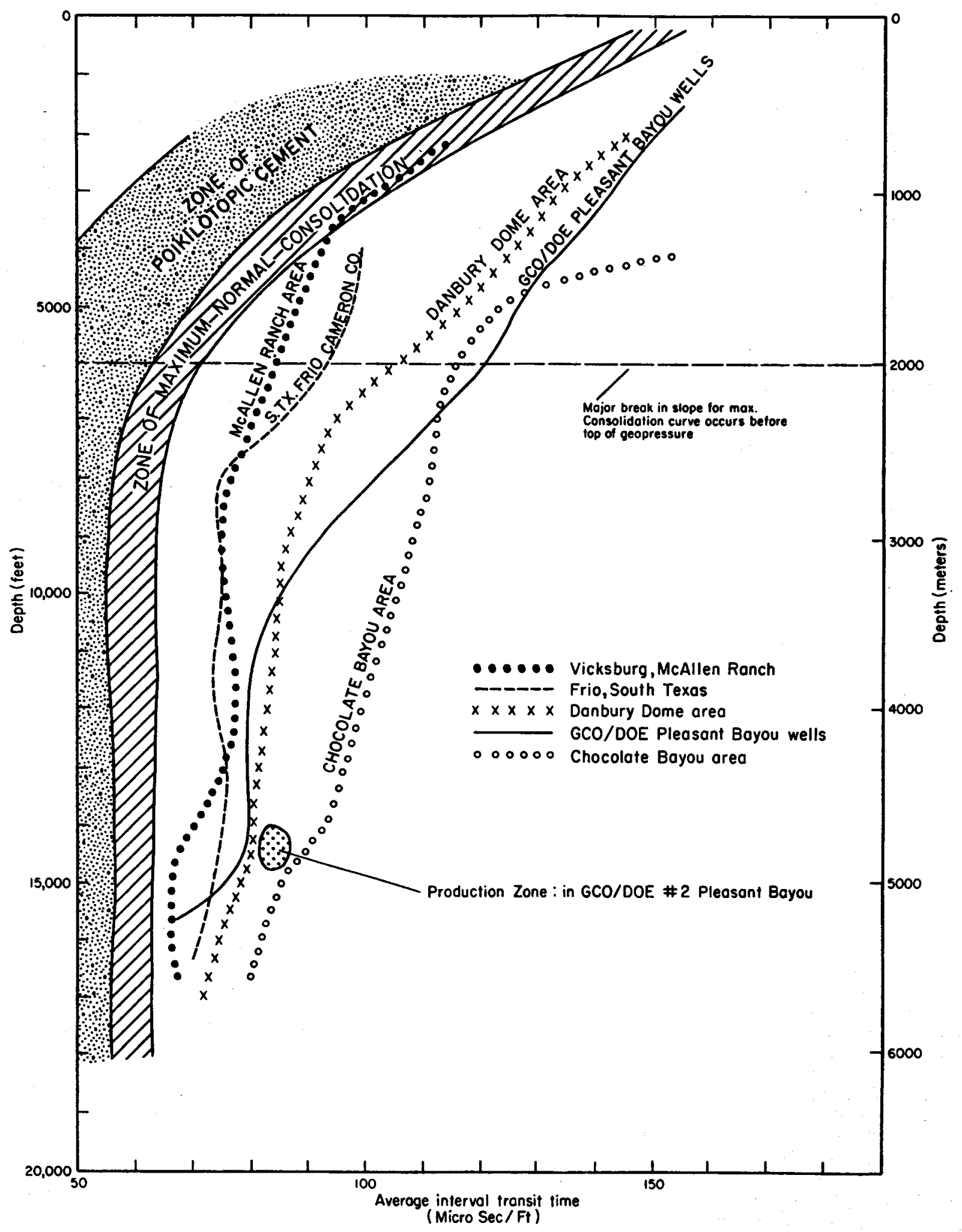

Figure 46. Interval transit time versus depth plots for the two study areas. 


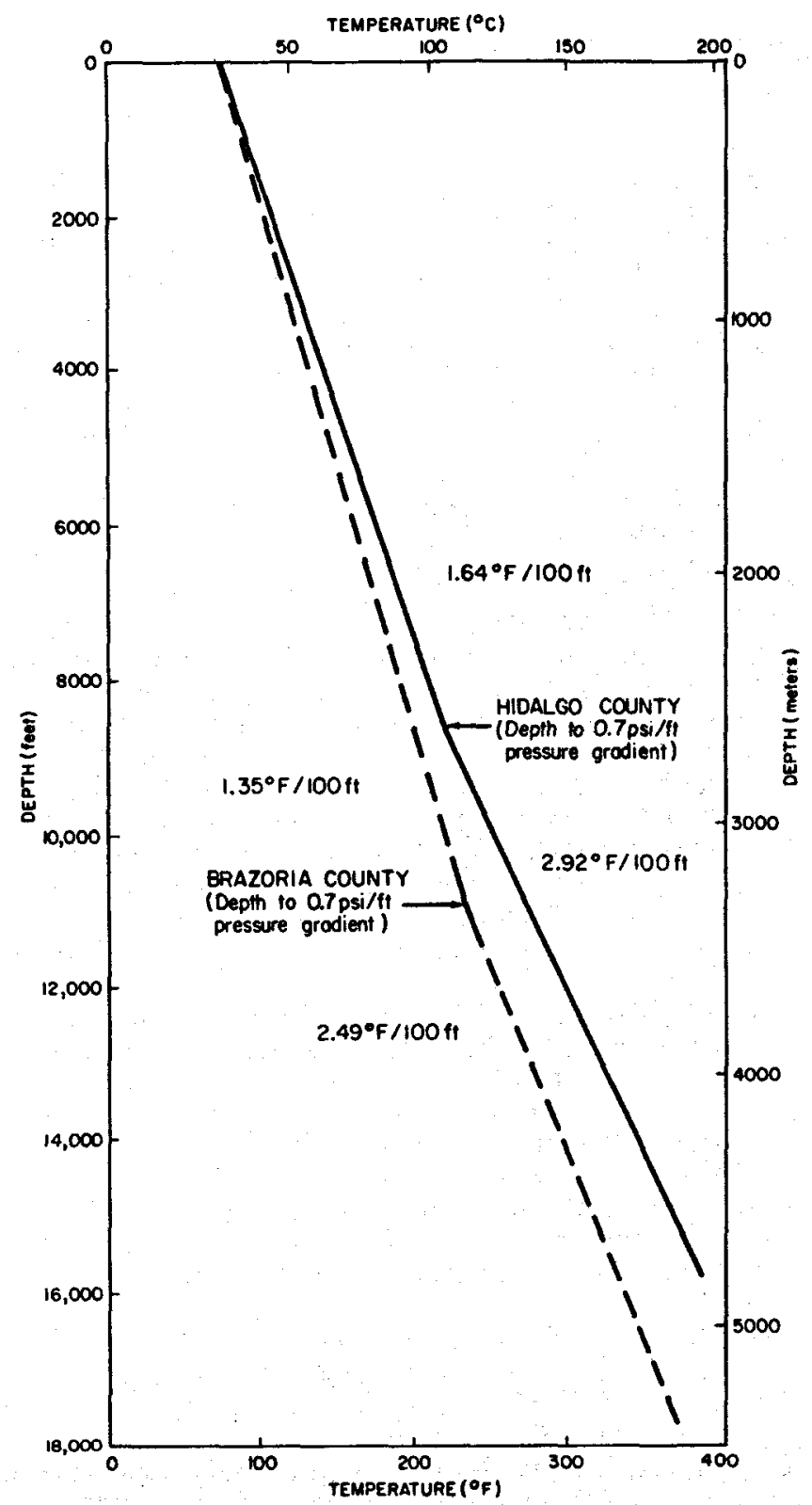

Figure 47. Comparison of temperature verus depth curves for Chocolate Bayou/Danbury Dome area (Brazoria County) and McAllen Ranch area (Hidalgo County).
In the Chocolate Bayou/Danbury Dome area Frio sandstones contain fewer unstable constituents and have been exposed to lower temperatures during burial. These rocks probably never contained authigenic carbonates on the extensive scale found in the South Texas Vicksburg. Secondary porosity was not affected by major late-stage carbonate precipitation. Thus, Frio sandstones of Brazoria County have the greatest potential for deep reservoir quality of all Texas Gulf Coast Tertiary sandstones (Bebout and others, 1978).

Frio sandstones from the Pleasant Bayou geothermal test wells exhibit mineralogic trends that are largely consistent with those trends observed in the larger set of all Brazoria County Frio samples; the detrital mineralogies are comparable, as are the diagenetic sequences we have reconstructed. The Pleasant Bayou test sites were selected for the favorable porosities, permeabilities, and sand volumes characterizing the Frio Formation in the geopressured zone of this area, relative to other areas of Brazoria County (Bebout and others, 1978; 1980). Within the geopressured zone, the best reservoir is the medium-grained, bed-load fluvial channel deposit occurring from approximately 14,640 to $14,710 \mathrm{ft}(4,460$ to $4,480 \mathrm{~m})$ deep in the Pleasant Bayou No. 2 well (Bebout and others, 1980). This unit deviates most from the "typical" Brazoria County Frio sandstones we have described. In 15 of 16 samples from this interval, authigenic calcite constitutes no more than 2 percent of the sandstone. These rocks were apparently not subjected to the late-stage calcite cementation that occurred elsewhere along the Gulf Coast, so abundant secondary porosity was preserved. Depositional matrix is a minor constituent in these sandstones; 13 of the samples are matrix free. The absence of matrix was a major factor controlling the development of secondary porosity by permitting leaching fluids to permeate the sandstones.

Thus, even in a region with broadly favorable reservoir potential, extreme variations in reservoir quality exist on a smaller scale. Factors that determine reservoir quality of individual sandstone units include depositional environment at a local level, relative proportions of porosity types, extent of authigenic mineral development, and pore geometry as related to permeability. Consideration of these regional and local reservoir quality controls can aid in predicting the distribution of reservoirs suitable for geopressured geothermal energy production.

\section{ACKNOWLEDGMENTS}

Subsurface data for this project were provided by the following companies: Forest Oil Corporation; Core Laboratories, Incorporated; Shell Oil Company; Exxon Company, U.S.A.; Gulf Oil Company; and Tenneco Oil Company. The help of these organizations is sincerely appreciated.

Numerous individuals have also assisted us: Robert Berg of Texas A\&M University arranged for us to sample Vicksburg cores from the McAllen Ranch Field; Lynton S. Land, The University of Texas at Austin, performed the isotopic analyses and contributed significantly in development of diagenetic models; Marianne Dodge, Heritage Oil Corporation, helped us with her considerable knowledge of Gulf Coast diagenesis; Kinji Magara, Consultant, and Ray Gregory, Bureau of Economic Geology, improved our understanding of geopressure and geothermal gradients; and Thomas Dunn, Amoco Research, arranged for us to use the Amoco SEM, from which we acquired a number of excellent pictures and useful analyses. We thank these individuals for their valuable contributions. We also appreciate the reviews by our colleagues at the Bureau, William $R$. Kaiser and William E. Galloway, and by Marc B. Edwards of Kerr, Jain \& Associates. Their efforts have contributed noticeably to the clarity of this report. Our research was supported by the U.S. Department of Energy under contract number DE-AC08-79ET27111. The publication was typeset by Charlotte Frere, under the supervision of Lucille Harrell, edited by Amanda R. Masterson, designed by Judy P. Culwell, and assembled by Jamie S. Haynes. 


\section{REFERENCES}

Bebout, D. G., Loucks, R. G., and Gregory, A. R., 1978, Frio sandstone reservoirs: The University of Texas at Austin, Bureau of Economic Geology Report of Investigations No. $91,92 \mathrm{p}$.

Berg, R. R., Marshall, W. D., and Shoemaker, P.W., 1979, Structural and depositional history, McAllen Ranch Field, Hidalgo County, Texas: Gulf Coast Association of Geological Societies Transactions, v. 29, p. 24-28.

Boles, J. R., 1979, Active albitization of plagioclase in Gulf Coast Tertiary sandstones: Geological Society of America, Abstracts with Programs, v. 11, no. 7, p. 391. 1980, Calcium budget in Frio sandstones, southwest Texas (abs.): American Association of Petroleum Geologists Bulletin, v. 64, no. 5, p. 678 .

Boles, J. R., and Franks, S. G., 1979, Clay diagenesis in Wilcox sandstones of southwest Texas: implications of smectite diagenesis on sandstone cementation: Journal of Sedimentary Petrology, v. 49, no. 1, p. 55-70.

Bonham, L. C., 1980, Migration of hydrocarbons in compacting basins: American Association of Petroleum Geologists Bulletin, v. 64, no. 4, p. 549-567.

Bruce, C. H., 1973, Pressured shale and related sediment deformation: mechanism for development of regional contemporaneous faults: American Association of Petroleum Geologists Bulletin, v. 57, no. 5, p. 878-886.

Burst, J. F., 1969, Diagenesis of Gulf Coast clayey sediments and its possible relationship to petroleum migration: American Association of Petroleum Geologists Bulletin, v. 53, no. 1, p. 73-93.

Carothers, W. W., and Kharaka, Y. K., 1980, Stable carbon isotopes of $\mathrm{HCO}_{3}{ }^{-}$in oilfield waters - implications for the origin of $\mathrm{CO}_{2}$ : Geochimica et Cosmochimica Acta, v. 44, no. 2, p. 323-332.

Clayton, R. N., Friedman, I., Graf, D. L., Mayeda, T. K., Meents, W. F., and Shimp, N. F., 1972, The origin of saline formation waters, I: isotopic composition: Journal of Geophysical Research, v. 71, p. 3869-3882.

Craig, H., 1961, Standard for reporting concentration of deuterium and oxygen-18 in natural waters: Science, v. 33, p. 1833-1934.

1966, Isotopic composition and origin of the Red Sea and Salton Sea geothermal brines: Science, v. 154 , p. $1544-1548$.

Dapples, E. C., 1972, Some concepts of cementation and lithification of sandstones: American Association of Petroleum Geologists Bulletin, v. 56, no. 1, p. 3-25.

de Segonzac, C. D., 1970, The transformation of clay minerals during diagenesis and low-grade metamorphism: a review: Sedimentology, v. 15, p. 281-346.

Dickey, P. A., Collins, A. G., and Fajardo, I., 1972, Chemical composition of deep formation waters in southwestern Louisiana: American Association of Petroleum Geologists Bulletin, v. 56, no. 8, p. 1530 1533.

Dickinson, W. R., 1970, Interpreting detrital modes of graywacke and arkose: Journal of Sedimentary Petrology, v. 40, no. 2, p. 695-707.

Epstein, S., Graf, D. L., and Degens, E. T., 1963, Oxygen isotope studies on the origin of dolomite, in Craig, $\mathrm{H}$., Miller, S. L., and Wasserburg, G. J., eds., Isotopic and cosmic chemistry: Amsterdam, North Holland Publishing Company, $188 \mathrm{p}$.

Eslinger, E., 1971, Mineralogy and oxygen isotope ratios of hydrothermal and low-grade metamorphic argillaceous rocks: Cleveland, Ohio, Case Western Reserve University, Ph.D. dissertation, 205 p.

Folk, R. L., 1974, Petrology of sedimentary rocks: Austin, Texas, Hemphill Publishing Company, 182 p.

Folk, R. L., and Assereto, R., 1974, Giant aragonite rays and baroque white dolomite in Tepee fillings, Triassic of Lombardy, Italy (abs.): American Association of Petroleum Geologists and Society of Economic Paleontologists and Mineralogists, Annual Meeting Abstracts, v. 1, p. 34-35.

Foster, W. R., and Custard, H. C., 1980, Smectite-illite transformation - role in generating and maintaining geopressure (abs.): American Association of Petroleum Geologists Bulletin, v. 64, no. 5, p. 708.

Freed, R. L., 1980, Shale mineralogy and burial diagenesis in four geopressured wells, Hidalgo and Brazoria Counties, Texas, in Loucks, R. G., Richmann, D. L., and Milliken, K. L., Factors controlling reservoir quality in Tertiary sandstones and their significance to geopressured geothermal production: U.S. Department of Energy, Division of Geothermal Energy, Contract No. DOE/ET/27111-1, Appendix A, p. 111-172.

Friedman, I., and O'Neil, J. R., 1977, Compilation of stable isotope fractionation factors of geochemical interest: U.S. Geological Survey Professional Paper 440-KK, 12 p., 49 figs.

Galloway, W. E., 1977, Catahoula Formation of the Texas Coastal Plain - depositional systems, mineralogy, structural development, ground-water flow history, and uranium distribution: The University of Texas at Austin, Bureau of Economic Geology Report of Investigations No. 87, 59 p.

Garbarini, J. M., and Carpenter, A. B., 1978, Albitization of plagioclase by oil-field waters: Geological Society of America, Abstracts with Programs, v. 10, no. 7, p. 406.

Graf, D. L., Friedman, I., and Meents, W. F., 1965, The origin of saline formation waters, II: isotopic fractionation by shale micropore systems: Illinois State Geological Survey Circular 393, $32 \mathrm{p}$.

Gregory, A. R., and Backus, M. M., 1980, Geopressured formation parameters, geothermal well, Brazoria County, Texas, in Dorfman, M. H., and Fisher, W. L., eds., Fourth Geopressured Geothermal Energy Conference Proceedings: The University of Texas at Austin, Center for Energy Studies, v. 1, p. 235-311.

Han, J. H., 1980, Deltaic systems and associated growth faulting of Vicksburg Formation (Oligocene), South Texas: American Association of Petroleum Geologists and Society of Economic Paleontologists and Mineralogists Abstracts, p. 62.

Hitchon, B., and Friedman, I., 1969, Geochemistry and origin of formation waters in the western Canada sedimentary basin, I: stable isotopes of hydrogen and oxygen: Geochimica et Cosmochimica Acta, v. 33, no. 11, p. 1321-1349.

Hower, J., Eslinger, E. V., Hower, M. E., and Perry, E. A., 1976, Mechanism of burial metamorphism of argillaceous sediment, I: mineralogical and chemical evidence: Geological Society of America Bulletin, v. 87, no. 5, p. 725-737.

Jones, P. J., 1975, Geothermal and hydrocarbon regimes, northern Gulf of Mexico Basin, in Dorfman, 
M. H., and Deller, R. W., eds., First Geopressured Geothermal Energy Conference Proceedings: The University of Texas at Austin, Center for Energy Studies, p. 15-97.

Kharaka, Y. K., Callender, E., and Carothers, W. W., $1977 \mathrm{a}$, Geochemistry of geopressured geothermal waters from the Texas Gulf Coast: Third Geopressured Geothermal Energy Conference Proceedings: Lafayette, University of Southwestern Louisiana, v. 1, p. GI-121 - GI-165.

Kharaka, Y. K., Callender, E., and Wallace, R. H., 1977b, Geochemistry of geopressured geothermal waters from the Frio Clay in the Gulf Coast region of Texas: Geology, v. 5, p. 241-244.

Kharaka, Y. K., Lico, M. S., Wright, V. A., and Carothers, W. W., 1980, Geochemistry of formation waters from Pleasant Bayou No. 2 well and adjacent areas in coastal Texas, in Dorfman, M. H., and Fisher, W. L., eds., Fourth Geopressured Geothermal Energy Conference Proceedings: The University of Texas at Austin, Center for Energy Studies, v. 1, p. 168-193.

Land, L. S., 1980, The isotopic and trace element chemistry of dolomite: the state of the art: Society of Economic Paleontologists and Mineralogists Special Publication No. 28, p. 87-110.

Land, L. S., and Dutton, S. P., 1978, Cementation of a Pennsylvanian deltaic sandstone: isotopic data: Journal of Sedimentary Petrology, v. 48, no.4, p. 1187-1176.

Laniz, R. V., Stevens, R. E., and Norman, M. B., 1964, Staining of plagioclase feldspar and other minerals with F, D, and C red no. 2: U.S. Geological Survey Professional Paper 501-B, p. B152-B153.

Lewis, C. R., and Rose, S. C., 1970, A theory relating high temperatures and overpressures: Journal of $\mathrm{Pe}$ troleum Technology, v. 22, no. 1, p. 11-16.

Lindholm, R. C., and Finkelman, R. B., 1972, Calcite staining: semiquantitative determination of ferrous iron: Journal of Sedimentary Petrology, v. 42, no. 1, p. 239-242.

Lindquist, S. J., 1977, Secondary porosity development and subsequent reduction, overpressured Frio Formation sandstone (Oligocene), South Texas: Gulf Coast Association of Geological Societies Transactions, v. 27, p. 99-107.

Loucks, R. G., 1978, Sandstone distribution and potential for geopressured-geothermal energy production in the Vicksburg Formation along the Texas Gulf Coast: Gulf Coast Association of Geological Societies Transactions, v. 28, p. 239-271.

Loucks, R. G., Bebout, D. G., and Galloway, W. E., 1977, Relationship of porosity formation and preservation to sandstone consolidation theory - Gulf Coast Lower Tertiary Frio Formation: Gulf Coast Association of Geological Societies Transactions, v. 27, p. $109-120$.

Loucks, R. G., Dodge, M. M., and Galloway, W. E., 1979, Sandstone consolidation analysis to delineate areas of high-quality reservoirs suitable for production of geopressured geothermal energy along the Texas Gulf Coast: U.S. Department of Energy, Division of Geothermal Energy, EG-77-5-05-5554, 97 p.

Loucks, R. G., Richmann, D. L., and Milliken, K. L., 1980, Factors controlling porosity and permeability in geopressured Frio sandstone reservoirs, General Crude OilDepartment of Energy Pleasant Bayou Test Wells, Brazoria County, Texas, in Dorfman, M. H., and Fisher, W. L., eds., Fourth Geopressured Geothermal Energy Conference Proceedings: The
University of Texas at Austin, Center for Energy Studies, v. 1, p. 46-82.

Magara, K., 1975, Importance of aquathermal pressuring effect in Gulf Coast: American Association of Petroleum Geologists Bulletin, v. 59, no. 10, p. 2037-2045. 1978, Compaction and fluid migration, practical petroleum geology: Amsterdam, Elsevier, $311 \mathrm{p}$.

McCrea, J. M., 1950, On the isotopic chemistry of carbonates and a paleotemperature scale: Journal of Chemistry and Physics, v. 18, p. 849-857.

Perry, E. A., and Hower, J., 1970, Burial diagenesis in Gulf Coast sediments: Clays and Clay Minerals, v. 18, no. 3 , p. $165-177$.

Pittman, E. D., 1979, Porosity, diagenesis, and productive capability of sandstone reservoirs: Society of Economic Paleontologists and Mineralogists Special Publication 26, p. 159-173.

Powers, M. C., 1967, Fluid release mechanisms in compacting marine mudrocks and their importance in oil exploration: American Association of Petroleum Geologists Bulletin, v. 51, no. 7, p. 1240-1253.

Richmann, D. L., Milliken, K. L., Loucks, R. G., and Dodge, M. M., 1980, Mineralogy, diagenesis, and porosity in Vicksburg sandstones, McAllen Ranch Field, Hidalgo County, Texas: Gulf Coast Association of Geological Societies Transactions, v. 30, p.473-481.

Ritch, H. J., and Kozik, H. G, 1971, Petrophysical study of overpressured sandstone reservoirs, Vicksburg Formation, McAllen Ranch Field, Hidalgo County, Texas: Society of Production Well Log Analysts, 12th Annual Logging Symposium, 14 p.

Schmidt, G. W., 1973, Interstitial water composition and geochemistry of deep Gulf Coast shales and sandstones: American Association of Petroleum Geologists Bulletin, v. 57, no. 2, p. 321-337.

Schmidt, V., and McDonald, D. A., 1979, The role of secondary porosity in the course of sandstone diagenesis: Society of Economic Paleontologists and Mineralogists, Special Publication 26, p. 175-207.

Sharp, J. M., 1980, Temperature and pressure relations in thick sequences of accumulating sediments (abs.): American Association of Petroleum Geologists Bulletin, v. 64, no. 5 , p. 782 .

Syers, J. K., Chapman, S. L., Jackson, M. L., Rex, R. W., and Clayton, N. L., 1968, Quartz isolation from rocks, sediments and soils for determination of oxygen isotopic composition: Geochimica et Cosmochimica Acta, v. 32, no. 9, p. 1022-1025.

Van Olphen, H., 1963, Compaction of clay sediments in the range of molecular particle distances, in Clays and clay minerals: 11th National Clays and Clay Mineral Conference Proceedings: New York, Macmillan, p. 178-187.

Weaver, C. E., 1958, Geologic interpretation of argillaceous sediments: American Association of Petroleum Geologists Bulletin, v. 42, no. 2, p. 254-309.

Weaver, C. E., and Beck, K. C., 1971, Clay water diagenesis during burial: how mud becomes gneiss: Geological Society of America Special Paper 134, $96 \mathrm{p}$.

Winker, C., 1979, Late Pleistocene fluvial-deltaic deposition, Texas Gulf coastal plain and shelf: The University of Texas at Austin, Master's thesis, $187 \mathrm{p}$.

Yeh, H.-W., and Savin, S. M., 1977, Mechanism of burial metamorphism of argillaceous sediments, III: oxygen-isotope evidence: Geological Society of America Bulletin, v. 88, no. 9, p. 1321-1330. 


\section{APPENDICES}

\section{Appendix A. Use of Isotopic Data for Interpretation of Diagenetic History}

Authigenic carbonates, quartz, albite, and kaolinite from sandstones in General Crude Oil/Department of Energy Nos. 1 and 2 Pleasant Bayou and other nearby wells have been analyzed for stable isotopes to gain a better understanding of diagenetic history. Stable isotope ratios of authigenic materials are useful in this regard because they represent a record of the conditions that prevailed at the time precipitation occurred.

Oxygen and carbon isotopic values for both minerals and water are reported in $\delta$-notation:

$$
\delta^{18} \mathrm{O}(\%)=\frac{\left({ }^{18} \mathrm{O} /{ }^{16} \mathrm{O}\right) \text { sample }-\left({ }^{18} \mathrm{O} /{ }^{16} \mathrm{O}\right) \text { standard }}{\left({ }^{18} \mathrm{O} /{ }^{16} \mathrm{O}\right) \text { standard }} \times 1,000
$$

The standard, SMOW (standard mean ocean water; Craig, 1961), the approximate $\delta^{18} \mathrm{O}$ for sea water $=0$, is commonly used to report oxygen isotopic values for water and silicates. The PDB standard (Peedee belemnite; defined by Urey) is often used for oxygen and carbon isotope measurements on carbonates. A mineral or water is said to become "lighter" as the proportion of the light isotope increases, whereas "heavier" samples have relatively greater amounts of the heavier isotope. If $\delta^{18} \mathrm{O}$ of sample $\mathrm{A}$ is less than $\delta^{18} \mathrm{O}$ of sample $\mathrm{B}, \mathrm{A}$ is said to be "lighter" $\operatorname{than} \mathrm{B}$, or $\mathrm{B}$ "heavier" than A.

Figure A-1 illustrates a typical relationship between the oxygen isotopic composition of a mineral and the temperature and isotopic composition of water $\left(\delta^{18} \mathrm{O}_{\mathrm{H}_{2}} \mathrm{O}\right)$ under which the mineral formed. A single $\delta^{18} \mathrm{O}_{\min }$ value can result from a number of $\delta^{18} \mathrm{O}_{\mathrm{H}_{2}}$-temperature combinations. According to the diagram, the $\delta^{18} \mathrm{O}_{\min }$ value shown by the solid curve could have formed equally well from sea water at some low temperature (1) or from a heavier water (x) at some higher temperature (2). Equations relating these three parameters (temperature, $\delta^{18} \mathrm{O}_{\mathrm{H}_{2} \mathrm{O}}, \delta^{18} \mathrm{O}_{\min }$ ) for common authigenic minerals are available in numerous publications (Friedman and O'Neil, 1977).

To make interpretations about the temperature at which a mineral formed, it is necessary to know the limits of $\delta^{18} \mathrm{O}_{2} \mathrm{O}$ variations. Likewise, if the limits of temperature variation are known, the $\delta^{18} \mathrm{O}_{\min }$ value can reveal something about the $\delta^{18} \mathrm{O}_{2} \mathrm{O}$ value in effect at the time of cementation.

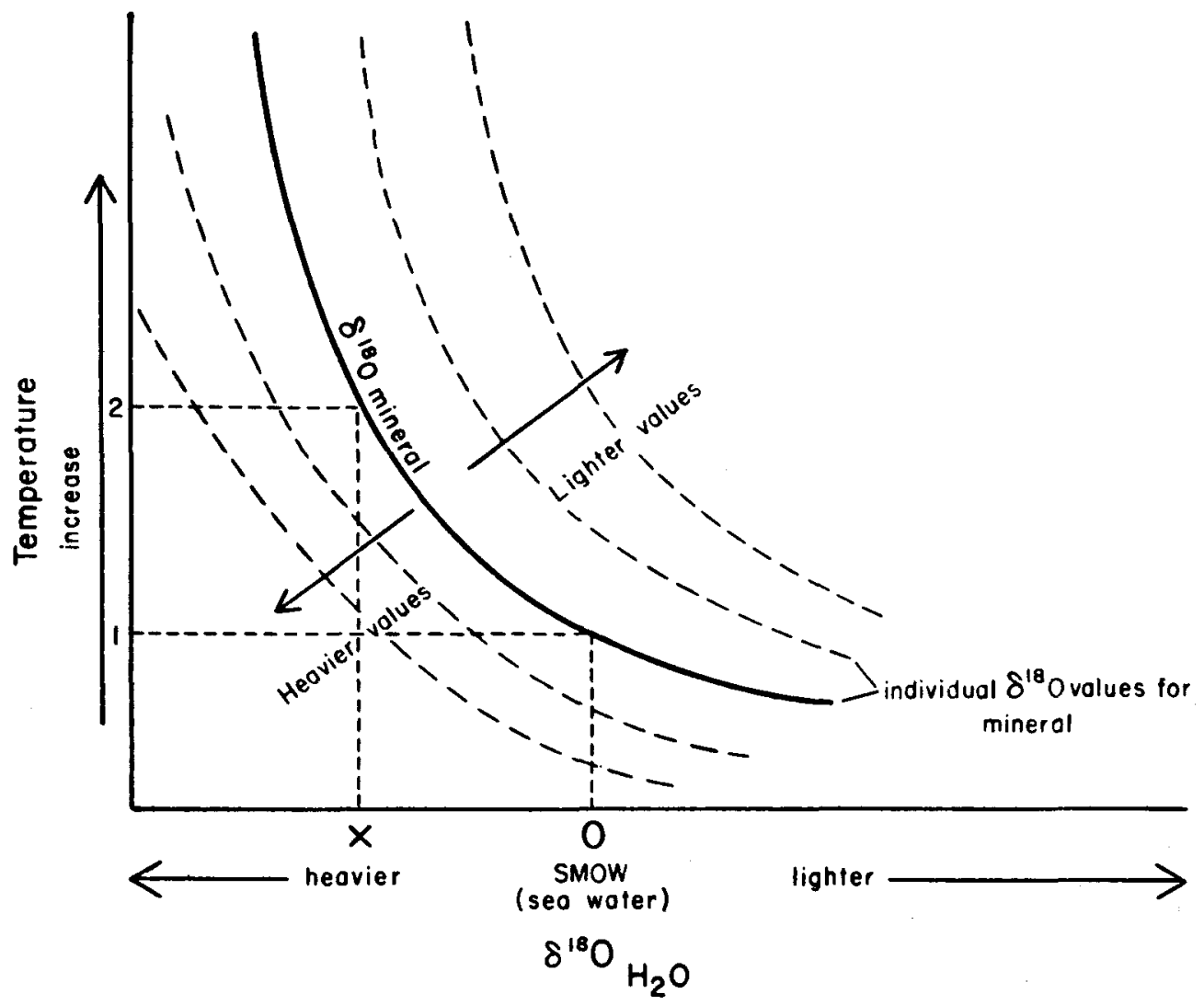

Figure A-1. Schematic diagram showing the relationship between temperature, $\delta^{18} \mathrm{O}_{\mathrm{H}_{2} \mathrm{O}}$, and $\delta^{18} \mathrm{O}$ of a mineral precipitated from aqueous solution. Each curve represents a single $\delta^{18} \mathrm{O}_{\min }$ value. $\delta^{18} \mathrm{O}_{\min }$ values become progressively "heavier" or "lighter," relative to the solid curve, in the directions of the diagonal arrows. See the text for further explanations. 


\section{Appendix B. Isotopic Analyses of Carbonate Minerals}

Sample

Number* Well Name

1024 Phillips

No. 1 Houston " $Z$ "

$1038 \mathrm{C}$

1038D Phillips

Phillips

No. 2 Gunderson

1045

$1061 \mathrm{~A}$

1061B-C

1061B-D

$1065 \mathrm{C}$

1065D

Phillips

No. 2 Gunderson

Phillips

No. 2 Rekdahl

Phillips

No. 2 Rekdahl

Phillips

No. 2 Rekdahl

Phillips

No. 2 Rekdahl

Phillips
No. 2 Rekdahl

1077 Phillips

No. F-3 Houston

$1086 \quad$ Phillips

No. F-3 Houston

1091 Phillips

No. 1 Houston "GG"

1148C Phillips

No. 1 Houston "JJ"

1148D Phillips

No. 1 Houston "JJ"

1161

$1173 \mathrm{C}$

1173D

1177

$1200 \mathrm{~B}$

1203

1205

1206

$1208 \mathrm{C}$

1208D

$1221 \mathrm{C}$ $\begin{array}{ccc}\text { Depth } & \delta^{18} \mathrm{O}(\%) & \delta^{13} \mathrm{C}(\%) \\ \text { (ft) } & \mathrm{PDB} & \mathrm{PDB}\end{array}$

Petrographic Features $\begin{array}{llll}12,858 & -10.3 & -1.0 \quad \begin{array}{l}\text { Minor grain replacement; mainly cement; post- } \\ \text { quartz overgrowth. }\end{array}\end{array}$

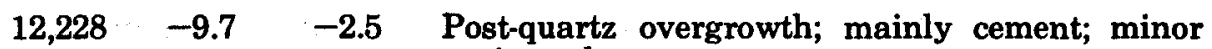
grain replacement.

12,228 -7.9 -3.5 Post-quartz overgrowth; mainly grain replacement; minor cement.

$12,236-6.9+1.3 \quad$ Pre-quartz overgrowth poikilotopic cement; some grain replacement.

$12,371 \quad-7.9 \quad-5.9 \quad$ Pre-quartz overgrowth nodule; non-ferroan poikilotopic calcite.

$12,371 \quad-8.1 \quad-5.1 \quad$ Post-quartz overgrowth (?); mainly grain replacement.

12,371 -7.4 -4.5 Post-quartz overgrowth (?); mainly grain replacement, some cement.

12,398 -10.4 -2.15 Poikilotopic non-ferroan cement and grain replacement; post-quartz overgrowth (?).

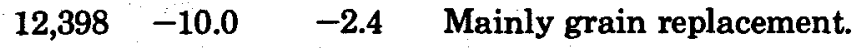

11,951 -5.7 -2.7 Pre-quartz overgrowth; poikilotopic cement with minor grain replacement.

12,175 -7.6 -3.7 Mainly grain replacement; undulose.

14,821 -10.3 -2.9 Poikilotopic undulose ferroan calcite; some grain replacement.

16,189 -10.9 -3.1 Non-ferroan calcite grain replacement and minor cement; post-quartz overgrowth.

16,189 $-8.8 \quad-2.3 \quad$ Ferroan dolomite grain replacement, subhedral.

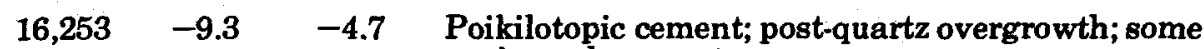
grain replacement.

$16,755-10.0 \quad-3.2 \quad$ Approximatèly $1 / 3$ grain replacement, $2 / 3$ poikilotopic cement; post-quartz overgrowth (?).

$16,755-8.5 \quad-2.05 \quad$ Mostly grain replacement.

$16,779-8.8 \quad-5.0 \quad$ Subequal cement and grain replacement; unknown relative timing to quartz.

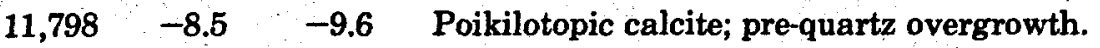

$11,810 \quad-8.3 \quad-6.4 \quad$ Poikilotopic calcite; pre-quartz overgrowth.

$12,172 \quad-8.0 \quad-8.7 \quad$ Poikilotopic calcite; pre-quartz overgrowth.

$12,174 \quad-5.4 \quad-25.9 \quad$ Nodule of strongly undulose poikilotopic calcite; mainly cement but also invades grains; pre-quartz overgrowth.

Nodule of strongly undulose poikilotopic calcite; mainly cement but also invades grains; pre-quartz overgrowth.

Some portion of nodule; not seen in thin section.

Grain replacement and cement. 
Sample

Number* Well Name

1221D Humble No. 1

Freeport-Sulphur

1232C Humble No. 1

Skrabanek

1232D Humble No. 1

Skrabanek

1962 GCO/DOE No. 1

Pleasant Bayou

1963 GCO/DOE No. 1

Pleasant Bayou

1964 GCO/DOE No. 1

Pleasant Bayou

1965 GCO/DOE No. 1

Pleasant Bayou

1968 GCO/DOE No. 1

Pleasant Bayou

1969 GCO/DOE No. 1

Pleasant Bayou

1970 GCO/DOE No. 1

Pleasant Bayou

1976 GCO/DOE No. 1

Pleasant Bayou

1980 GCO/DOE No. 1

Pleasant Bayou

1981 GCO/DOE No. 1

Pleasant Bayou

1994 GCO/DOE No. 1

Pleasant Bayou

1999 GCO/DOE No. 1

Pleasant Bayou

2010 GCO/DOE No. 1

Pleasant Bayou

2011 GCO/DOE No. 1

Pleasant Bayou

$2028 \mathrm{C}$

GCO/DOE No. 1

Pleasant Bayou

2028D GCO/DOE No. 1

Pleasant Bayou

$2029 \mathrm{C}$

2029D

GCO/DOE No. 1

Pleasant Bayou

2050

2065

GCO/DOE No. 1

Pleasant Bayou
Depth $\quad \delta^{18} \mathrm{O}(\%) \quad \delta^{13} \mathrm{C}(\% \circ)$

(ft) PDB PDB Petrographic Features

12,257 -7.0 -4.4 Grain replacement and cement.

17,783 -11.0 -4.8 Mainly grain replacement; some cement; postquartz overgrowth.

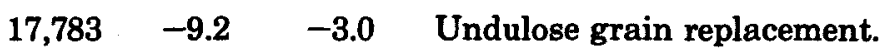

4,345 $\quad-5.0 \quad-3.4 \quad 87.2 \%$ poikilotopic ferroan calcite, $8.5 \%$ nonferroan grain replacement, $4.3 \%$ foraminifers; prequartz overgrowth.

$6,705-7.0 \quad-4.0 \quad 94.4 \%$ sparry ferroan calcite, $2.6 \%$ non-ferroan grain replacement; pre-quartz overgrowth.

6,707 -4.4 $-2.7 \quad$ Euhedral, pore-filling ferroan dolomite.

10,215 $-8.3 \quad-10.1 \quad 79.7 \%$ poikilotopic ferroan calcite, $20.3 \%$ nonferroan grain replacement.

$10,223-6.1 \quad-9.5 \quad 69.6 \%$ poikilotopic ferroan calcite, $30.4 \%$ nonferroan grain replacement.

$10,225 \quad-7.2 \quad-7.0 \quad 41.6 \%$ poikilotopic calcite (mostly ferroan), $54.2 \%$ non-ferroan grain replacement, $4.2 \%$ foraminifers.

$10,227-5.4 \quad-4.7 \quad 100 \%$ non-ferroan grain replacement.

$10,259-8.4 \quad-8.8 \quad 90.0 \%$ poikilotopic ferroan calcite, $10.0 \%$ grain replacement (mostly non-ferroan).

10,267 $-6.2 \quad-7.8 \quad 77.5 \%$ poikilotopic ferroan calcite, $22.5 \%$ nonferroan grain replacement.

$11,733-8.15 \quad-7.9 \quad 95.8 \%$ poikilotopic ferroan calcite, $4.2 \%$ non-ferroan grain replacement.

$11,763-9.3 \quad-6.7 \quad$ Non-ferroan poikilotopic calcite; minor foraminifers; post-quartz overgrowth.

$11,773 \quad-9.0 \quad-7.1 \quad$ Non-ferroan poikilotopic calcite; post-quartz overgrowth.

$14,061-11.2 \quad-6.1 \quad$ Non-ferroan calcite cement.

$14,080-11.2 \quad-5.65 \quad$ Non-ferroan calcite cement.

14,775 $-8.7 \quad-2.5 \quad$ Not recognized in thin section.

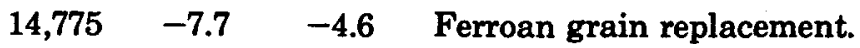

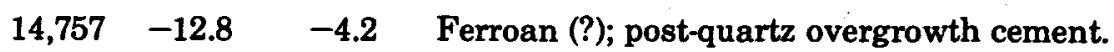

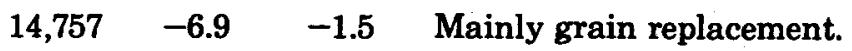

Pleasant Bayou

$15,183-12.2 \quad-2.4$

Post-quartz overgrowth cement; some grain replacement.

15,586 -11.7 0.0 Post-quartz overgrowth cement; some grain replacement. 


\section{Appendix B (cont.)}

Sample

Number* Well Name

Depth $\quad \delta^{18} \mathrm{O}(\% \circ) \quad \delta^{13} \mathrm{C}(\% \circ)$

$\begin{array}{llllll}\text { GCO/DOE No. 2 } & 14,685 & -8.7 & -5.3 & \begin{array}{l}\text { Poikilotopic ferroan calcite; pre-quartz overgrowth; } \\ 91.5 \% \text { cement, 8.5\% grain replacement. }\end{array}\end{array}$

Mollusk GCO/DOE No. $1 \quad 4,830 \quad-0.23 \quad+3.25$ Unaltered aragonite; from Miocene shale.

Mollusk GCO/DOE No. $1 \quad 5,200 \quad-2.3 \quad-0.9 \quad$ Unaltered aragonite; from Miocene shale.

Pleasant Bayou

* $\mathrm{D}=$ dolomite; $\mathrm{C}=$ calcite associated with dolomite; samples with no letter designation are calcite.

Appendix C. Electron Microprobe Data

Table C-1. Pleasant Bayou samples - carbonate compositions

\begin{tabular}{|c|c|c|c|c|c|c|c|}
\hline Sample No. & Depth & Description & $\% \mathrm{MgO}$ & $\% \mathrm{SrO}$ & $\% \mathrm{CaO}$ & $\% \mathrm{MnO}$ & $\% \mathrm{FeO}$ \\
\hline \multirow[t]{3}{*}{1962} & $4,345 \mathrm{ft}(1,324 \mathrm{~m})$ & Poikilotopic cement & $\begin{array}{l}0.41 \\
0.53 \\
0.49 \\
0.48 \\
0.57 \\
0.56 \\
0.45 \\
0.38 \\
0.28 \\
0.32\end{array}$ & $\begin{array}{l}0.04 \\
0.11 \\
0.03 \\
0.07 \\
0.09 \\
0.11 \\
0.09 \\
0.04 \\
0.10 \\
0.14\end{array}$ & $\begin{array}{l}57.93 \\
56.80 \\
52.95 \\
52.77 \\
50.95 \\
51.37 \\
52.50 \\
52.78 \\
54.20 \\
54.05\end{array}$ & $\begin{array}{l}0.28 \\
0.15 \\
0.20 \\
0.23 \\
0.25 \\
0.13 \\
0.30 \\
0.30 \\
0.18 \\
0.13\end{array}$ & $\begin{array}{l}2.37 \\
2.72 \\
2.54 \\
2.79 \\
2.93 \\
2.76 \\
2.63 \\
2.59 \\
1.48 \\
1.86\end{array}$ \\
\hline & & Grain replacement & 0.11 & 0.18 & 54.86 & 0.00 & 0.03 \\
\hline & & Foraminifera & $\begin{array}{l}0.07 \\
0.09\end{array}$ & $\begin{array}{l}0.12 \\
0.13\end{array}$ & $\begin{array}{l}55.44 \\
54.35\end{array}$ & $\begin{array}{l}0.02 \\
0.00\end{array}$ & $\begin{array}{l}0.00 \\
0.03\end{array}$ \\
\hline \multirow[t]{2}{*}{1999} & $11,773 \mathrm{ft}(3,589 \mathrm{~m})$ & Poikilotopic cement & $\begin{array}{l}0.34 \\
0.37 \\
0.23 \\
0.28 \\
0.39 \\
0.29 \\
0.39 \\
0.41\end{array}$ & $\begin{array}{l}0.06 \\
0.16 \\
0.07 \\
0.13 \\
0.25 \\
0.09 \\
0.18 \\
0.15\end{array}$ & $\begin{array}{l}\mathbf{5 5 . 3 3} \\
\mathbf{5 5 . 4 9} \\
\mathbf{5 6 . 3 8} \\
\mathbf{5 5 . 1 8} \\
\mathbf{5 5 . 4 8} \\
\mathbf{5 4 . 7 5} \\
\mathbf{5 4 . 3 2} \\
\mathbf{5 7 . 2 9}\end{array}$ & $\begin{array}{l}1.16 \\
1.19 \\
1.02 \\
1.18 \\
0.93 \\
1.01 \\
1.20 \\
1.36\end{array}$ & $\begin{array}{l}0.73 \\
0.82 \\
0.56 \\
0.75 \\
0.68 \\
0.70 \\
0.86 \\
0.98\end{array}$ \\
\hline & & Grain replacement & 0.32 & 0.19 & 53.54 & 1.26 & 0.85 \\
\hline 2040 & $15,162 \mathrm{ft}(4,621 \mathrm{~m})$ & Sparry cement & 0.03 & 0.02 & 57.19 & 0.09 & 0.00 \\
\hline \multirow[t]{2}{*}{2045} & $15,173 \mathrm{ft}(4,625 \mathrm{~m})$ & Sparry cement & $\begin{array}{l}0.33 \\
0.21 \\
0.21\end{array}$ & $\begin{array}{l}0.07 \\
0.15 \\
0.08\end{array}$ & $\begin{array}{l}\mathbf{5 7 . 2 8} \\
\mathbf{5 7 . 9 8} \\
\mathbf{5 7 . 4 8}\end{array}$ & $\begin{array}{l}1.12 \\
0.86 \\
1.12\end{array}$ & $\begin{array}{l}0.65 \\
0.46 \\
0.32\end{array}$ \\
\hline & & Grain replacement & $\begin{array}{l}0.38 \\
0.15 \\
0.25 \\
0.12\end{array}$ & $\begin{array}{l}0.09 \\
0.07 \\
0.06 \\
0.06\end{array}$ & $\begin{array}{l}\mathbf{5 7 . 0 2} \\
\mathbf{5 5 . 6 1} \\
\mathbf{5 8 . 5 5} \\
\mathbf{5 7 . 7 2}\end{array}$ & $\begin{array}{l}1.39 \\
0.76 \\
0.90 \\
1.53\end{array}$ & $\begin{array}{l}0.59 \\
0.36 \\
0.46 \\
0.29\end{array}$ \\
\hline 2069 & $14,285 \mathrm{ft}(4,476 \mathrm{~m})$ & Poikilotopic cement & $\begin{array}{l}0.59 \\
0.54 \\
0.60 \\
0.57 \\
0.44 \\
0.51 \\
0.53 \\
0.51 \\
0.45 \\
0.51\end{array}$ & $\begin{array}{l}0.11 \\
0.17 \\
0.17 \\
0.17 \\
0.16 \\
0.11 \\
0.12 \\
0.14 \\
0.13 \\
0.14\end{array}$ & $\begin{array}{l}55.26 \\
53.64 \\
54.30 \\
52.89 \\
54.38 \\
54.15 \\
54.73 \\
\mathbf{5 3} .80 \\
\mathbf{5 4 . 8 9} \\
\mathbf{5 4 . 0 6}\end{array}$ & $\begin{array}{l}1.25 \\
1.28 \\
1.39 \\
1.32 \\
1.18 \\
1.39 \\
1.33 \\
1.23 \\
1.23 \\
1.28\end{array}$ & $\begin{array}{l}2.12 \\
2.35 \\
2.04 \\
2.23 \\
1.67 \\
1.86 \\
2.00 \\
1.98 \\
1.70 \\
2.04\end{array}$ \\
\hline
\end{tabular}




\begin{tabular}{|c|c|c|c|c|c|c|c|}
\hline \multirow{4}{*}{$\begin{array}{l}\text { Sample No. } \\
2069\end{array}$} & \multicolumn{4}{|c|}{$\begin{array}{c}\text { Appendix C (cont.) } \\
\text { Table C-1 (cont.) }\end{array}$} & \multirow[b]{2}{*}{$\% \mathrm{CaO}$} & \multirow[b]{2}{*}{$\% \mathrm{MnO}$} & \multirow[b]{2}{*}{$\% \mathrm{FeO}$} \\
\hline & \multirow{3}{*}{$\begin{array}{c}\text { Depth } \\
14,685 \mathrm{ft}(4,476 \mathrm{~m})\end{array}$} & Description & $\% \mathrm{MgO}$ & \%SrO & & & \\
\hline & & Poikilotopic cement & $\begin{array}{l}0.55 \\
0.46 \\
0.52 \\
0.55 \\
0.48 \\
0.46 \\
0.43\end{array}$ & $\begin{array}{l}0.14 \\
0.16 \\
0.17 \\
0.10 \\
0.12 \\
0.13 \\
0.12\end{array}$ & $\begin{array}{l}54.59 \\
56.62 \\
56.73 \\
53.94 \\
54.66 \\
54.14 \\
\mathbf{5 3 . 0 7}\end{array}$ & $\begin{array}{l}1.09 \\
1.28 \\
1.26 \\
1.24 \\
1.26 \\
1.09 \\
1.07\end{array}$ & $\begin{array}{l}2.13 \\
1.88 \\
1.86 \\
1.98 \\
1.80 \\
1.97 \\
1.86\end{array}$ \\
\hline & & Grain replacement & $\begin{array}{l}0.14 \\
0.28 \\
0.30\end{array}$ & $\begin{array}{l}0.16 \\
0.13 \\
0.12\end{array}$ & $\begin{array}{l}56.34 \\
57.76 \\
55.92\end{array}$ & $\begin{array}{l}1.60 \\
1.38 \\
1.52\end{array}$ & $\begin{array}{l}0.71 \\
1.02 \\
1.00\end{array}$ \\
\hline \multicolumn{8}{|c|}{ Table C-2. McAllen Ranch Field samples - carbonate compositions } \\
\hline Sample No. & Depth & Description & $\% \mathrm{MgO}$ & \%SrO & $\% \mathrm{CaO}$ & $\% \mathrm{MnO}$ & $\% \mathrm{FeO}$ \\
\hline 2136 & $11,791 \mathrm{ft}(3,594 \mathrm{~m})$ & Sparry cement & $\begin{array}{l}0.22 \\
0.18 \\
0.20 \\
0.19 \\
0.15 \\
0.19 \\
0.19 \\
0.14 \\
0.20\end{array}$ & $\begin{array}{l}0.32 \\
0.30 \\
0.28 \\
0.31 \\
0.28 \\
0.32 \\
0.30 \\
0.27 \\
0.33\end{array}$ & $\begin{array}{l}\mathbf{5 0 . 5 9} \\
\mathbf{5 6 . 1 9} \\
\mathbf{5 4 . 4 7} \\
\mathbf{5 4 . 8 0} \\
\mathbf{5 5 . 3 2} \\
\mathbf{5 3 . 9 5} \\
\mathbf{5 5 . 1 8} \\
\mathbf{5 5 . 7 8} \\
\mathbf{5 5 . 4 6}\end{array}$ & $\begin{array}{l}0.46 \\
0.41 \\
0.41 \\
0.43 \\
0.38 \\
0.48 \\
0.46 \\
0.36 \\
0.43\end{array}$ & $\begin{array}{l}0.41 \\
0.34 \\
0.30 \\
0.39 \\
0.36 \\
0.42 \\
0.36 \\
0.30 \\
0.35\end{array}$ \\
\hline \multirow[t]{2}{*}{2235} & $12,500 \mathrm{ft}(3,810 \mathrm{~m})$ & Sparry cement & $\begin{array}{l}0.14 \\
0.00\end{array}$ & $\begin{array}{l}0.01 \\
0.03\end{array}$ & $\begin{array}{l}55.24 \\
56.45\end{array}$ & $\begin{array}{l}0.04 \\
0.05\end{array}$ & $\begin{array}{l}0.01 \\
0.00\end{array}$ \\
\hline & & Grain replacement & 0.14 & 0.04 & 54.12 & 0.05 & 0.03 \\
\hline \multirow[t]{2}{*}{2258} & $12,656 \mathrm{ft}(3,858 \mathrm{~m})$ & Sparry cement & 0.05 & 0.07 & 55.73 & 0.30 & 0.15 \\
\hline & & Grain replacement & 0.69 & 0.04 & 53.92 & 1.32 & 0.02 \\
\hline
\end{tabular}

Table C-3. Pleasant Bayou samples - feldspar compositions

\begin{tabular}{|c|c|c|c|c|c|c|c|c|c|c|}
\hline Sample No. & Depth & $\begin{array}{c}\% \\
\mathrm{Na}_{2} \mathrm{O}\end{array}$ & $\begin{array}{c}\% \\
\mathrm{MgO}\end{array}$ & $\begin{array}{c}\% \\
\mathrm{Al}_{2} \mathrm{O}_{3}\end{array}$ & $\begin{array}{c}\% \\
\mathrm{SiO}_{2}\end{array}$ & $\begin{array}{c}\% \\
\mathrm{~K}_{2} \mathrm{O}\end{array}$ & $\begin{array}{c}\% \\
\mathrm{CaO}\end{array}$ & $\stackrel{\%}{\mathrm{TiO}_{2}}$ & $\begin{array}{c}\% \\
\mathrm{FeO}\end{array}$ & Type* \\
\hline 1962 & $4,345 \mathrm{ft}(1,324 \mathrm{~m})$ & $\begin{array}{l}0.96 \\
0.91 \\
0.93\end{array}$ & $\begin{array}{l}0.02 \\
0.02 \\
0.02\end{array}$ & $\begin{array}{l}18.66 \\
18.49 \\
18.58\end{array}$ & $\begin{array}{l}65.78 \\
66.03 \\
65.90\end{array}$ & $\begin{array}{l}15.29 \\
15.07 \\
15.18\end{array}$ & $\begin{array}{l}0.07 \\
0.03 \\
0.05\end{array}$ & $\begin{array}{l}0.00 \\
0.04 \\
0.00\end{array}$ & $\begin{array}{l}0.00 \\
0.00 \\
0.00\end{array}$ & $\begin{array}{l}\mathbf{K}_{1} \\
\mathbf{K}_{\mathbf{2}} \\
\mathbf{K}_{\mathbf{a}}\end{array}$ \\
\hline 1999 & $11,773 \mathrm{ft}(3,589 \mathrm{~m})$ & $\begin{array}{r}11.93 \\
0.60 \\
11,71 \\
11.84\end{array}$ & $\begin{array}{l}0.00 \\
0.02 \\
0.00 \\
0.02\end{array}$ & $\begin{array}{l}20.11 \\
18.99 \\
20.08 \\
19.63\end{array}$ & $\begin{array}{l}68.60 \\
63.82 \\
69.18 \\
67.61\end{array}$ & $\begin{array}{r}0.05 \\
15.57 \\
0.04 \\
0.06\end{array}$ & $\begin{array}{l}0.04 \\
0.06 \\
0.06 \\
0.06\end{array}$ & $\begin{array}{l}0.00 \\
0.00 \\
0.00 \\
0.03\end{array}$ & $\begin{array}{l}0.00 \\
0.01 \\
0.00 \\
0.00\end{array}$ & $\begin{array}{l}\mathbf{P} \\
\mathbf{K} \\
\mathbf{P} \\
\mathbf{P}\end{array}$ \\
\hline 2040 & $15,162 \mathrm{ft}(4,621 \mathrm{~m})$ & $\begin{array}{r}0.33 \\
0.52 \\
11.37 \\
11.64\end{array}$ & $\begin{array}{l}0.00 \\
0.00 \\
0.02 \\
0.02\end{array}$ & $\begin{array}{l}18.89 \\
18.65 \\
19.82 \\
19.73\end{array}$ & $\begin{array}{l}65.63 \\
64.18 \\
68.71 \\
68.42\end{array}$ & $\begin{array}{r}16.39 \\
15.70 \\
0.01 \\
0.03\end{array}$ & $\begin{array}{l}0.00 \\
0.00 \\
0.27 \\
0.18\end{array}$ & $\begin{array}{l}0.00 \\
0.04 \\
0.07 \\
0.09\end{array}$ & $\begin{array}{l}0.00 \\
0.00 \\
0.00 \\
0.00\end{array}$ & $\begin{array}{l}\mathbf{K}_{c} \\
\mathbf{K}_{\mathbf{r}} \\
\mathbf{P}_{\mathbf{c}} \\
\mathbf{P}_{\mathbf{r}}\end{array}$ \\
\hline 2045 & $15,173 \mathrm{ft}(4,625 \mathrm{~m})$ & $\begin{array}{l}11.48 \\
11.85 \\
11.97 \\
11.82 \\
11.80 \\
11.49 \\
11.94 \\
12.13\end{array}$ & $\begin{array}{l}0.02 \\
0.02 \\
0.02 \\
0.02 \\
0.02 \\
0.02 \\
0.05 \\
0.03\end{array}$ & $\begin{array}{l}20.23 \\
19.79 \\
20.13 \\
20.00 \\
19.79 \\
19.37 \\
20.41 \\
19.86\end{array}$ & $\begin{array}{l}68.19 \\
69.43 \\
69.33 \\
69.05 \\
67.47 \\
68.54 \\
68.13 \\
70.12\end{array}$ & $\begin{array}{l}0.07 \\
0.04 \\
0.04 \\
0.12 \\
0.10 \\
0.09 \\
0.04 \\
0.02\end{array}$ & $\begin{array}{l}0.03 \\
0.04 \\
0.03 \\
0.02 \\
0.00 \\
0.02 \\
0.01 \\
0.02\end{array}$ & $\begin{array}{l}0.03 \\
0.00 \\
0.00 \\
0.00 \\
0.00 \\
0.00 \\
0.04 \\
0.06\end{array}$ & $\begin{array}{l}0.00 \\
0.00 \\
0.00 \\
0.00 \\
0.00 \\
0.00 \\
0.00 \\
0.00\end{array}$ & $\begin{array}{l}\mathbf{P} \\
\mathbf{P} \\
\mathbf{P}_{\mathbf{c}} \\
\mathbf{P}_{\mathbf{r}} \\
\mathbf{P}_{\mathbf{c}} \\
\mathbf{P}_{\mathbf{r}} \\
\mathbf{P}_{\mathbf{c}} \\
\mathbf{P}_{\mathbf{r}}\end{array}$ \\
\hline 2071 & $14,689 \mathrm{ft}(4,477 \mathrm{~m})$ & $\begin{array}{l}10.21 \\
10.62 \\
11.63 \\
11.62 \\
11.45\end{array}$ & $\begin{array}{l}0.02 \\
0.02 \\
0.00 \\
0.02 \\
0.02\end{array}$ & $\begin{array}{l}21.86 \\
21.73 \\
20.06 \\
20.12 \\
20.40\end{array}$ & $\begin{array}{l}66.11 \\
67.14 \\
72.79 \\
71.84 \\
71.21\end{array}$ & $\begin{array}{l}0.04 \\
0.06 \\
0.02 \\
0.02 \\
0.00\end{array}$ & $\begin{array}{l}2.68 \\
2.04 \\
0.04 \\
0.02 \\
0.01\end{array}$ & $\begin{array}{l}0.07 \\
0.04 \\
0.07 \\
0.04 \\
0.07\end{array}$ & $\begin{array}{l}0.05 \\
0.07 \\
0.02 \\
0.05 \\
0.02\end{array}$ & $\begin{array}{l}\mathbf{P}_{c} \\
\mathbf{P}_{\mathbf{r}} \\
\mathbf{P} \\
\mathbf{P} \\
\mathbf{P}\end{array}$ \\
\hline
\end{tabular}




\section{Appendix C (cont.)}

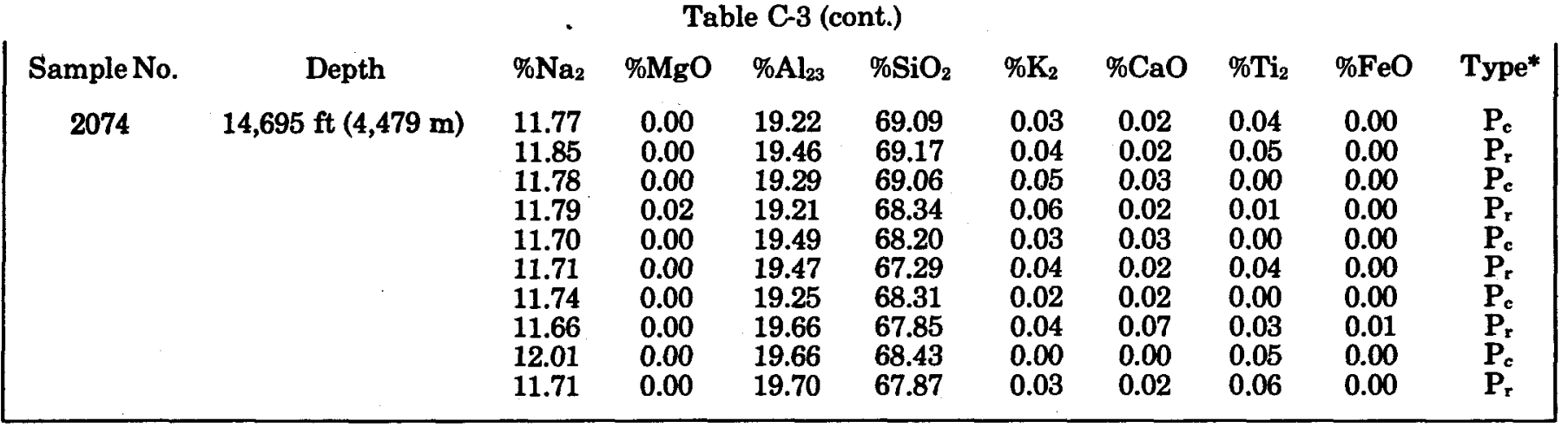

${ }^{*} \mathrm{~K}_{1,2}=$ repeated analyses of potassium feldspar grain.

$\mathrm{K}_{\mathrm{a}}$ = average of replicate analyses.

$\mathrm{P}$ or $\mathrm{K}=$ single analysis of plagioclase or potassium feldspar grain, respectively.

$\mathbf{P}_{\mathrm{c}}$ or $\mathrm{K}_{\mathrm{c}}=$ analysis of plagioclase or potassium feldspar core.

$\mathbf{P}_{\mathrm{r}}$ or $\mathrm{K}_{\mathrm{r}}=$ analysis of plagioclase or potassium feldspar rim.

Table C-4. McAllen Ranch Field samples - feldspar compositions

\begin{tabular}{|c|c|c|c|c|c|c|c|c|c|c|}
\hline Sample No. & Depth & $\begin{array}{c}\% \\
\mathrm{Na}_{2} \mathrm{O}\end{array}$ & $\stackrel{\%}{\mathrm{MgO}}$ & $\begin{array}{c}\% \\
\mathrm{Al}_{2} \mathrm{O}_{3}\end{array}$ & $\begin{array}{c}\% \\
\mathrm{SiO}_{2}\end{array}$ & $\begin{array}{c}\% \\
\mathrm{~K}_{2} \mathrm{O}\end{array}$ & $\stackrel{\%}{\mathrm{CaO}}$ & $\stackrel{\%}{\mathrm{TiO}_{2}}$ & $\begin{array}{c}\% \\
\mathrm{FeO}\end{array}$ & Type* \\
\hline 2110 & $10,829 \mathrm{ft}(3,301 \mathrm{~m})$ & 11.74 & 0.02 & 19.60 & 68.09 & 0.04 & 0.17 & 0.00 & 0.02 & $\mathbf{P}$ \\
\hline 2136 & $11,791 \mathrm{ft}(3,594 \mathrm{~m})$ & $\begin{array}{r}1.72 \\
11.62 \\
12.02 \\
11.82 \\
12.05 \\
12.07 \\
11.47 \\
1.00\end{array}$ & $\begin{array}{l}0.00 \\
0.02 \\
0.02 \\
0.02 \\
0.02 \\
0.02 \\
0.00 \\
0.02\end{array}$ & $\begin{array}{l}19.61 \\
19.72 \\
20.31 \\
20.25 \\
20.15 \\
20.01 \\
19.91 \\
18.80\end{array}$ & $\begin{array}{l}68.83 \\
70.00 \\
70.13 \\
69.90 \\
68.78 \\
70.13 \\
68.74 \\
66.38\end{array}$ & $\begin{array}{r}0.06 \\
0.07 \\
0.02 \\
0.04 \\
0.02 \\
0.05 \\
0.03 \\
15.28\end{array}$ & $\begin{array}{l}0.22 \\
0.11 \\
0.12 \\
0.17 \\
0.18 \\
0.14 \\
0.27 \\
0.04\end{array}$ & $\begin{array}{l}0.00 \\
0.04 \\
0.01 \\
0.00 \\
0.03 \\
0.00 \\
0.00 \\
0.05\end{array}$ & $\begin{array}{l}0.00 \\
0.00 \\
0.01 \\
0.00 \\
0.00 \\
0.00 \\
0.00 \\
0.09\end{array}$ & $\begin{array}{l}\mathbf{P} \\
\mathbf{P} \\
\mathbf{P} \\
\mathbf{P} \\
\mathbf{P} \\
\mathbf{P} \\
\mathbf{P} \\
\mathbf{K}\end{array}$ \\
\hline 2235 & $12,500 \mathrm{ft}(3,810 \mathrm{~m})$ & $\begin{array}{l}11.80 \\
11.84\end{array}$ & $\begin{array}{l}0.02 \\
0.02\end{array}$ & $\begin{array}{l}20.07 \\
19.59\end{array}$ & $\begin{array}{l}69.00 \\
69.06\end{array}$ & $\begin{array}{l}0.04 \\
0.04\end{array}$ & $\begin{array}{l}0.18 \\
0.25\end{array}$ & $\begin{array}{l}0.01 \\
0.01\end{array}$ & $\begin{array}{l}0.01 \\
0.00\end{array}$ & $\begin{array}{l}\text { o.g.** } \\
\text { o.g. }\end{array}$ \\
\hline 2236 & $12,519 \mathrm{ft}(3,816 \mathrm{~m})$ & $\begin{array}{l}11.61 \\
11.80 \\
11.52 \\
11.43 \\
11.65 \\
11.34\end{array}$ & $\begin{array}{l}0.02 \\
0.00 \\
0.00 \\
0.00 \\
0.00 \\
0.02\end{array}$ & $\begin{array}{l}19.86 \\
19.58 \\
19.75 \\
19.96 \\
19.58 \\
19.63\end{array}$ & $\begin{array}{l}69.57 \\
69.27 \\
69.37 \\
68.92 \\
68.88 \\
68.48\end{array}$ & $\begin{array}{l}0.04 \\
0.06 \\
0.04 \\
0.13 \\
0.00 \\
0.06\end{array}$ & $\begin{array}{l}0.04 \\
0.11 \\
0.16 \\
0.18 \\
0.14 \\
0.14\end{array}$ & $\begin{array}{l}0.00 \\
0.00 \\
0.00 \\
0.04 \\
0.00 \\
0.14\end{array}$ & $\begin{array}{l}0.00 \\
0.00 \\
0.00 \\
0.00 \\
0.00 \\
0.00\end{array}$ & $\begin{array}{l}\mathbf{o . g} \\
\mathbf{P} \\
\mathbf{P} \\
\mathbf{P}_{\mathbf{c}} \\
\mathbf{P}_{\mathbf{r}} \\
\mathbf{P}\end{array}$ \\
\hline
\end{tabular}

*See footnote under Pleasant Bayou feldspar compositions.

**o.g. = feldspar overgrowth. 